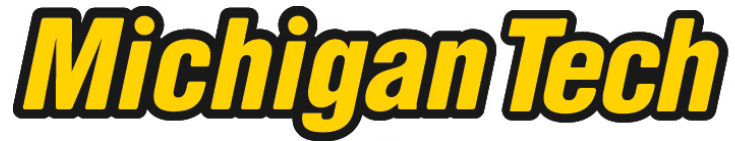 \\ Michigan Technological University Create the Future Digital Commons @ Michigan Tech
}

Dissertations, Master's Theses and Master's Reports - Open

Dissertations, Master's Theses and Master's

Reports

2012

\section{Effects of Chemical Deicers on Amphibian Communites}

Meagan Leigh Harless

Michigan Technological University

Follow this and additional works at: https://digitalcommons.mtu.edu/etds

Part of the Ecology and Evolutionary Biology Commons

Copyright 2012 Meagan Leigh Harless

\section{Recommended Citation}

Harless, Meagan Leigh, "Effects of Chemical Deicers on Amphibian Communites", Dissertation, Michigan Technological University, 2012.

https://doi.org/10.37099/mtu.dc.etds/492

Follow this and additional works at: https://digitalcommons.mtu.edu/etds

Part of the Ecology and Evolutionary Biology Commons 


\title{
EFFECTS OF CHEMICAL DEICERS ON AMPHIBIAN COMMUNITIES
}

\author{
By \\ Meagan Leigh Harless

\begin{abstract}
A DISSERTATION
Submitted in partial fulfillment of the requirements for the degree of DOCTOR OF PHILOSOPHY

(Biological Sciences)
\end{abstract}

MICHIGAN TECHNOLOGICAL UNIVERSITY

2012

(C) 2012 Meagan L. Harless 
This dissertation, "Effects of Chemical Deicers on Amphibian Communities," is hereby approved in partial fulfillment of the requirements for the Degree of DOCTOR OF PHILOSOPHY IN BIOLOGICAL SCIENCES.

Department of Biological Sciences

Signatures:

Dissertation Co-Advisor

Casey J Huckins

Dissertation Co-Advisor

Thomas G. Pypker

Department Chair

K. Michael Gibson

Date 


\section{Table of Contents}

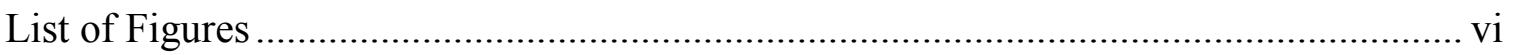

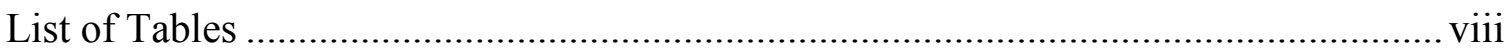

Preface

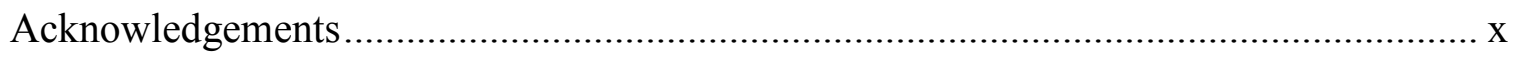

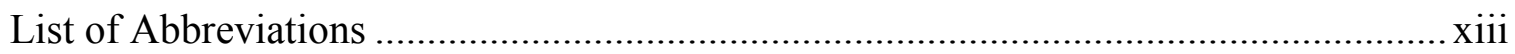

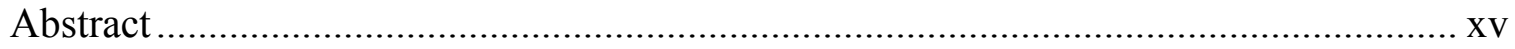

Chapter 1: Introduction and Review of the Ecological Effects of Chemical Deicers ........ 1

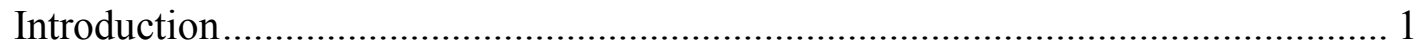

Impacts on Surface and Ground Waters .............................................................. 4

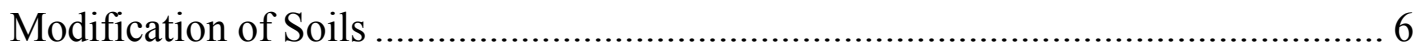

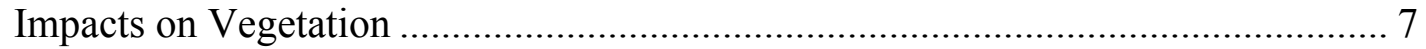

Impacts on Terrestrial and Aquatic Wildlife …………….................................. 8

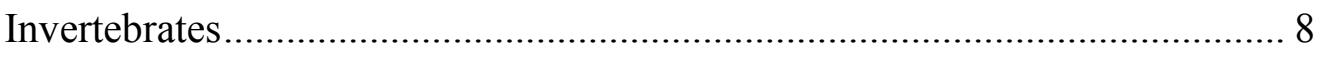

Mammals and Birds .................................................................................. 9

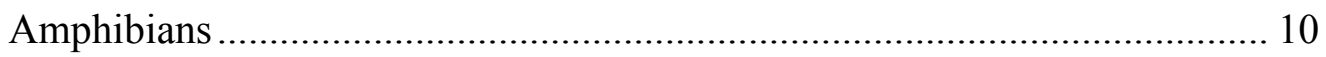

Alternatives to Road Salt ..................................................................................... 11

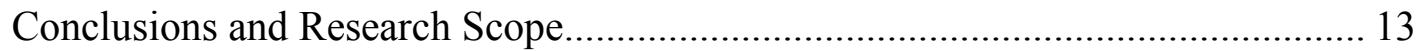

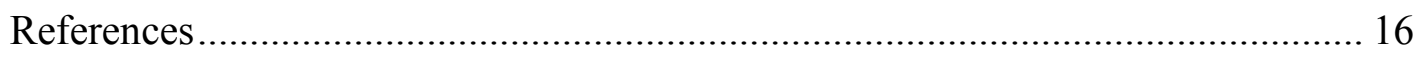

Chapter 2: Effects of Six Chemical Deicers on Larval Wood Frogs (Rana sylvatica)..... 25

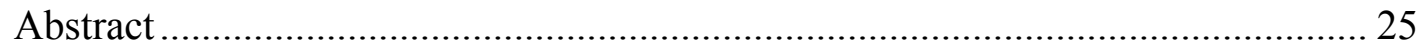

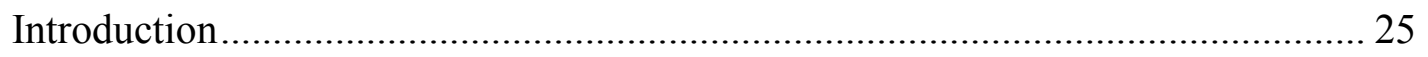

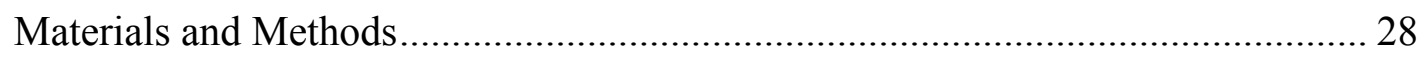

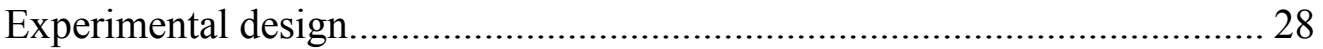

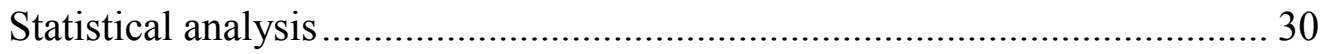

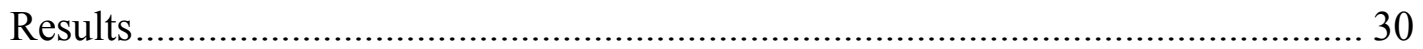




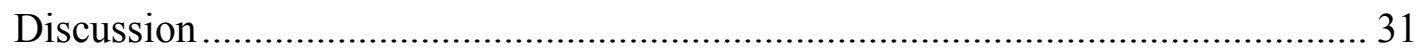

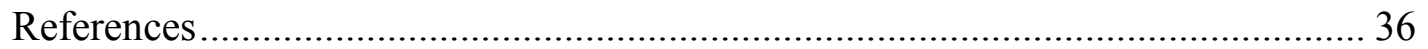

Chapter 3: Sublethal Effects of Road Salt (NaCl) Exposure to Larvae of Two Amphibian

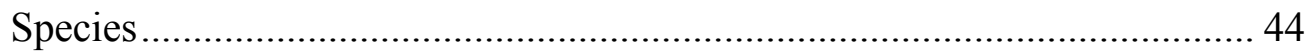

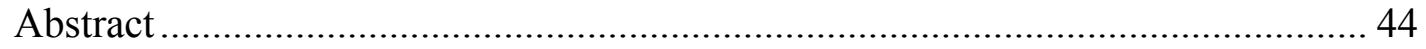

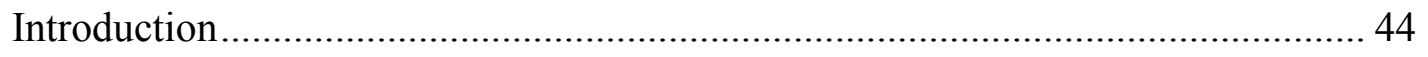

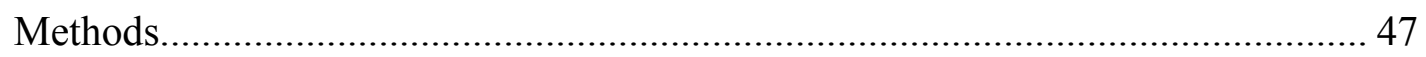

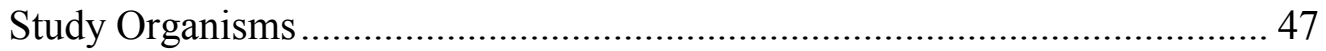

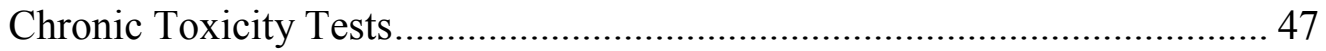

Environmental Concentrations................................................................. 49

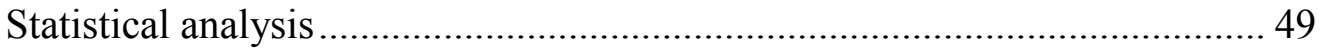

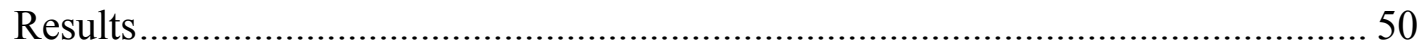

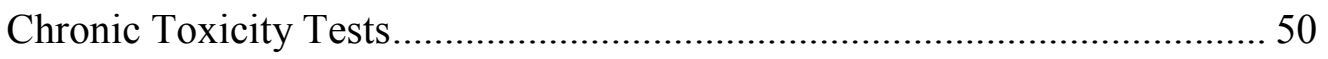

Environmental Concentrations.................................................................... 58

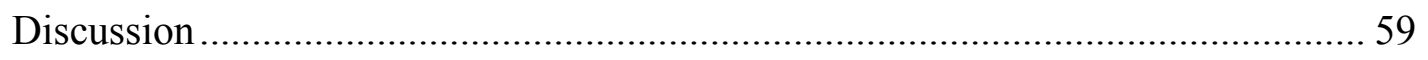

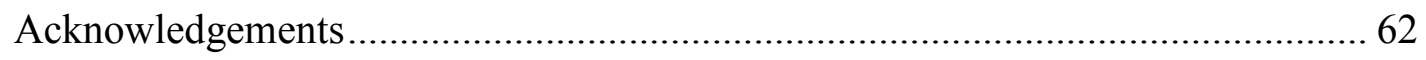

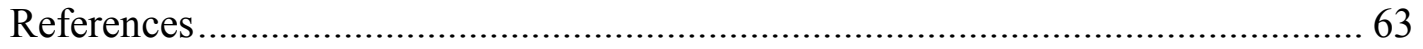

Chapter 4: An Analysis of Chloride Concentrations in Surface Water Bodies in

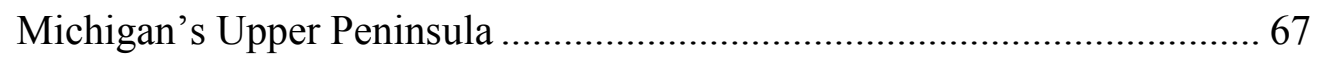

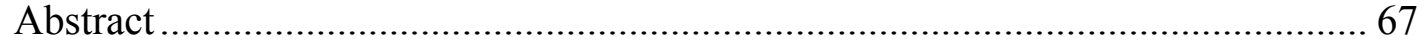

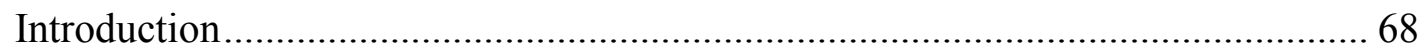

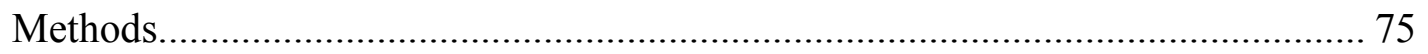

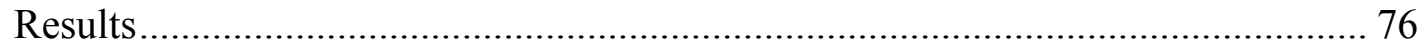

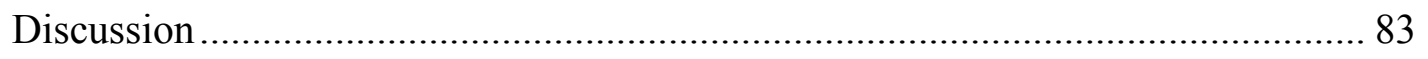

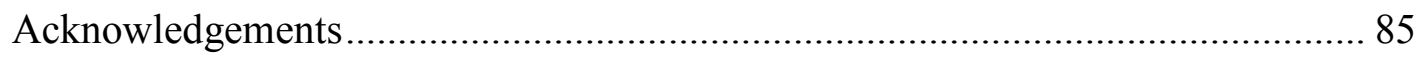

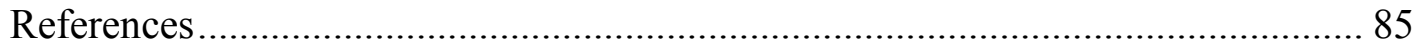

Chapter 5: Avoiding the Use of Specific Conductance to Estimate Chloride

Concentrations in Natural Water Bodies ..................................................... 89

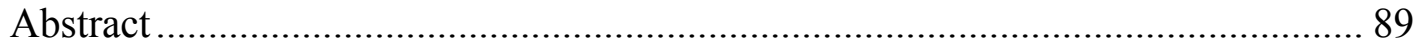


Introduction ..................................................................................... 90

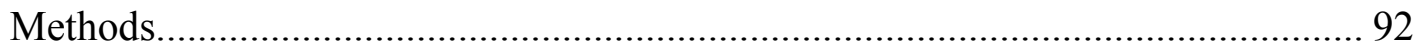

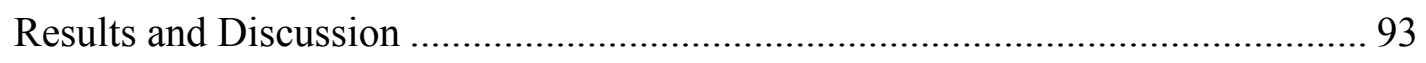

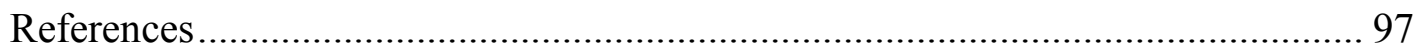

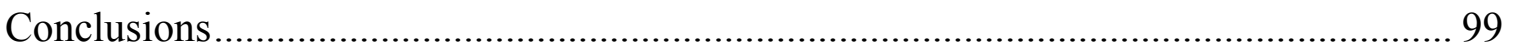

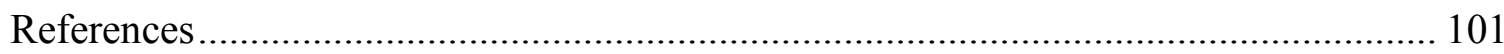

Appendix A: Request for Permission to Reproduce Previously Published Material...... 115 


\section{List of Figures}

Figure 2.1: Mean proportion of surviving Rana sylvatica tadpoles after 96 hours of exposure to 10 nominal test concentrations of six chemical deicers.

Figure 3.1: Mean proportion of Lithobates sylvatica (A) and L. clamitans (B) larvae surviving to the end of the test in each test concentration .................................... 52

Figure 3.2: Mean proportion of $L$. sylvatica larvae completing metamorphosis in each test concentration 54

Figure 3.3: Number of days for $L$ sylvatica larvae to complete metamorphosis in each test concentration 55

Figure 3.4: Mean proportion of Lithobates sylvatica (A) and L. clamitans (B) larvae exhibiting a physical deformity in each test concentration 56

Figure 3.5: Mean proportion of $L$. sylvatica larvae exhibiting abdominal edema in each test concentration with letter indicating significantly different groups. Error bars represent \pm 2 S.E.

Figure 3.6: Mean environmental concentration of $\mathrm{Cl}^{-}$in wetlands and vernal pools during

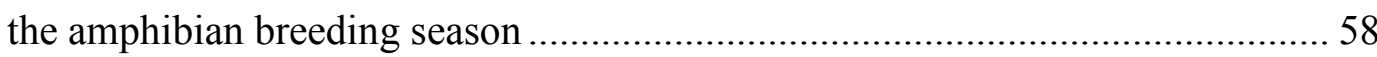

Figure 4.1: Density of roadways in the upper and lower peninsulas of Michigan, U.S.A.

Figure 4.2: Density of roadways in Michigan's Upper Peninsula highlighting the roads in the focal region in this study

Figure 4.3: Density of palustrine wetlands in Baraga, Houghton, and Keweenaw Counties of Michigan's Upper Peninsula

Figure 4.4: Relationship between chloride concentrations in perennial wetlands and distance from the nearest salt treated highway 78 
Figure 4.5: Mean environmental concentrations of chloride in surface water bodies during the amphibian breeding season 79

Figure 4.6: Distribution of chloride concentrations $\left(\mathrm{mgL}^{-1}\right)$ in surface water bodies across Baraga, Houghton, and Keweenaw Counties. ............................................. 80

Figure 4.7: Chloride concentration $\left(\mathrm{mgL}^{-1}\right)$ in sample locations in relation to the US 41

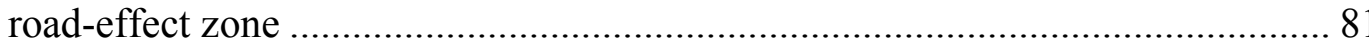

Figure 4.8: Length of primary, secondary, and tertiary roadways in Baraga, Houghton, and Keweenaw Counties of Michigan.......................................................... 82

Figure 5.1: The relationship between chloride concentration and specific conductance in

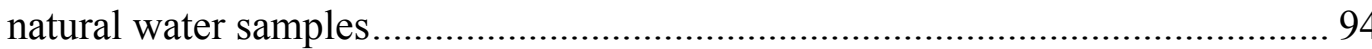

Figure 5.2: The relationship between specific conductance and sodium chloride $(\mathrm{NaCl})$ additions in natural water samples from Portage Lake, Michigan...................... 95

Figure 5.3: The relationship between specific conductance and sodium chloride $(\mathrm{NaCl})$ additions in deionized water. 


\section{List of Tables}

Table 2.1: Median lethal concentration values (LC50, $\mathrm{g} \mathrm{L}^{-1}$ ) for larval Rana sylvatica at $24,48,72$ and 96 hours of exposure to six chemical deicers during acute toxicity tests

Table 2.2: Median lethal concentration values ( $\left.\mathrm{LC} 50_{96-\mathrm{h}}, \mathrm{g} \mathrm{L}^{-1}\right)$ for larval amphibians native to the Northern and Eastern United States during acute exposure to deicing chemicals 42

Table 3.1: Mean (range) total length (TL) and snout-vent length (SVL) of L. sylvatica that completed metamorphosis and $L$. clamitans that survived to the end of the test exposure.

Table 4.1: Average salt $(\mathrm{NaCl})$ and sand use on county and state roads in Baraga, Houghton, and Keweenaw counties of Michigan

Table 4.2: Results of studies quantifying the road-effect zone for a variety of organisms

Table 4.3: Acreage of palustrine wetlands within a 40 meter and $250 \mathrm{~m}$ road-effect zone adjacent to US 41 in Baraga, Houghton, and Keweenaw Counties of Michigan. 83 


\section{Preface}

The article presented in Chapter 2 of this dissertation is used with permission from John Wiley and Sons as a collaborative effort with co-authors Drs. Casey Huckins, Jacqualine Grant, and Thomas Pypker. All data was collected on lands owned by the Keweenaw Bay Indian Community (KBIC, with permission from P. Nankervis) and the campus of Michigan Technological University in the laboratories of Drs. Grant, Huckins, and Pypker. My personal contribution to the article included collection of test organisms, completing the experiments, data analysis, and interpretation. I had a significant role in the authorship of the article. My collaborators contributed to the article through providing assistance with experimental design, data analysis, and manuscript preparation. See Appendix A for documentation of permission to republish this material. 


\section{Acknowledgements}

I could not have completed this work without the loving support of a number of amazing people in my life. Few people are as lucky as I am to have such a great support network in both their personal and professional lives. Firstly, my family has encouraged and supported me in all of my professional and academic endeavors. My parents, Lon and Joan, as well as my sister, Nicole, are always there to lend an ear to my struggles and to celebrate with me when I accomplish my goals. My family never ceased to encourage me in my progress, even though they may not understand what I am doing with my career. Thank you for all of your love and unwavering support over the years.

Secondly, I certainly would not be here if not for my fabulous committee members. I would like to thank Dr. Jackie Grant for bringing me to MTU to work on such a great research project and providing excellent advice in the early stages of my Ph.D. I learned a great deal about academia when working with Jackie. I would also like to commend Dr. Tom Pypker for stepping in to advise me on this project. Tom brought a fresh perspective to the project and has provided a wealth of professional advice. Dr. Casey Huckins has played a large role in the success of this project. He has given me the two most important components of this Ph.D.: lots of lab space to conduct my research and the best mentoring I have ever experienced. Dr. Huckins is a kind and thoughtful person with a quick wit and a wealth of knowledge on everything from music to ecological theory. His compassion for his students, coupled with his diplomatic approach to mentoring, creates one of the greatest Ph.D. advisors. Dr. Huckins has not only provided me with a wealth of teachable moments, but also with personal advice which I have learned a great deal from on this journey. I have him to thank in large part for my successes in completing my dissertation and becoming an effective instructor. I hope to one day be at least half of the mentor that he is. Last but not least, I would like to sincerely thank Dr. Amy Marcarelli for her contribution to this research in providing a broader perspective on the project, lab equipment, and honest answers to my many professional dilemmas. I am indebted to these wonderful mentors for their very kind and continued support. I feel awkward using "I" throughout this dissertation because it certainly was a team effort. 
I would certainly not be here without the encouragement of my Master's advisor, Dr. Bill Hayes. Bill not only helped me a great deal (both professionally and personally) in completing my M.S., but he also completed a very hard feat: encouraging me and boosting my self-confidence enough to where I believed in myself. I am eternally grateful for our many conversations and owe this accomplishment to him.

My involvement in the NSF GK12 Global Watershed Program through the guidance of Dr. Alex Mayer was a breath of fresh air in my time here at MTU. I would like to thank Alex for inviting me to participate in this program. Under his leadership, I have dramatically improved my communication skills and have gained a better understanding of the importance of science communication. Alex was a great mentor in this program and my experiences have opened many doors for future career plans. In this program I worked closely with Jean Dunstan and the wonderful teachers at E.B. Holman School. Jean allowed me to find my footing in teaching middle school science. I owe her a great deal in demonstrating how to be an effective and compassionate instructor. Her dedication to her class and her continuing drive to improve the experiences of her students are commendable traits. I will always remember the lessons that she has taught me. The teachers at E.B. Holman were wonderfully supportive and took the time to teach me about classroom management. I could not have asked for a greater school to be involved with. The middle school students were a joy to work with and learn alongside. Being in their classroom has reminded me why what I do as a scientist is so valuable.

And there are also many friends, fellow graduate students, community partners, and faculty to thank for their contributions to my success. Dr. Datta, Kefeng Li, and Ramana Reddy provided lab equipment and expertise to complete the ion chromatography analysis. Pam Nankervis in the KBIC was integral in helping me locate study sites and very excited about my research. My best friend Michelle Holiday-Crandall provided invaluable advice and constant love to keep me afloat. She is a rare friend and I am fortunate to have her in my life. I am indebted to Dr. Sarah Kiemle, Stephanie Olgren, Marty Holtgren, Rita Koch, and Yiru Chen for their friendship and for working through 
challenging times with me. Kim, Mark, and Lori Joki were my family away from home. Thank you for the many delicious dinners and for taking care of me when I needed it. Tim, Sandy, Sam, and Rose helped keep me sane with many meetings over board games and adult beverages. And finally, thanks to my four-legged friends Yukon and Tala for unconditional love, endless spirit, and for keeping me moving. You are the cutest stress relievers anyone could ask for. And for my three-legged friends, thank you to Gimpy, my box turtle, for your patience and standing (mostly brumating) by me over the past 17 years. I blame you for my fondness for the cold-blooded.

I am grateful to the following undergraduate research assistants for lending a hand in this project: E. Gorsalitz, K. Griffith, M. Mitchell, H. Erickson, E. Turos, N. DelPiccolo, D. Mudahl, E. Rogers, R. Alger, and many others who have braved formalin infused dead froglets and plenty of ticks in the name of science. The following organizations provided funding for this project: the DeVlieg Foundation, the Chicago Herpetological Society, the Western New York Herpetological Society, the Amphibian Specialist Group of the International Union for Conservation of Nature and Natural Resources, the Ecosystem Science Center at Michigan Technological University, Michigan Tech Transportation Institute, support from the MTU Global Watershed GK-12 program, and support from both the Forest Resources and Environmental Science as well as the Department of Biological Sciences at MTU. 


\section{List of Abbreviations}

A

ANOVA

ASTM

$B$

BOD

BPA

COD

$\mathrm{C}_{8} \mathrm{H}_{12} \mathrm{CaMgO}_{8}$

$\mathrm{C}_{4} \mathrm{H}_{6} \mathrm{CaO}_{4}$

$\mathrm{C}_{4} \mathrm{H}_{6} \mathrm{MgO}_{4}$

$\mathrm{CH}_{4} \mathrm{~N}_{2} \mathrm{O}$

$\mathrm{CH}_{3} \mathrm{OH}$

$\mathrm{Ca}^{2+}$

$\mathrm{CaCl}_{2}$

CALTRANS

$\mathrm{CH}_{3} \mathrm{COOK}$

$\mathrm{CHNaO}_{2}$

$\mathrm{Cl}^{-}$

CMA

DBP

$\mathrm{HCO}_{3}$

$\mathrm{K}^{+}$

KBIC

$\mathrm{KCl}$

$L$

$\mathrm{LC} 50$ or $\mathrm{LC}_{50}$

LC50 $24-\mathrm{h}$

LC50 58 -h

LC50 $52-\mathrm{h}$
Ambystoma

analysis of variance

American Society of Testing Materials

Bufo

biochemical oxygen demand

bisphenol A

chemical oxygen demand

calcium magnesium acetate

calcium acetate

magnesium acetate

urea

methanol

calcium ion

calcium chloride

California Department of Transportation

potassium acetate

sodium formate

chloride ion

calcium magnesium acetate

dibutyl phthalate

bicarbonate ion

potassium ion

Keweenaw Bay Indian Community

potassium acetate

\section{Lithobates}

median lethal concentration

median lethal concentration after 24 hours of exposure median lethal concentration after 48 hours of exposure median lethal concentration after 72 hours of exposure 


\begin{tabular}{|c|c|}
\hline LC50 $96-\mathrm{h}$ & median lethal concentration after 96 hours of exposure \\
\hline $\mathrm{Mg}^{2+}$ & magnesium ion \\
\hline $\mathrm{MgCl}_{2}$ & magnesium chloride \\
\hline MTU & Michigan Technological University \\
\hline $\mathrm{Na}^{+}$ & sodium ion \\
\hline $\mathrm{NaCl}$ & sodium chloride, road salt \\
\hline NDOT & Nevada Department of Transportation \\
\hline NOAA & National Oceanic and Atmospheric Administration \\
\hline$R$ & Rana \\
\hline S.E. & standard error \\
\hline $\mathrm{SO}_{4}^{2-}$ & sulfate ion \\
\hline SVL & snout-vent length \\
\hline TDS & total dissolved solids \\
\hline TL & total length \\
\hline USEPA & United States Environmental Protection Agency \\
\hline
\end{tabular}




\begin{abstract}
Roads and highways present a unique challenge to wildlife as they exhibit substantial impacts on the surrounding ecosystem through the interruption of a number of ecological processes. With new roads added to the national highway system every year, an understanding of these impacts is required for effective mitigation of potential environmental impacts. A major contributor to these negative effects is the deposition of chemicals used in winter deicing activities to nearby surface waters. These chemicals often vary in composition and may affect freshwater species differently. The negative impacts of widespread deposition of sodium chloride $(\mathrm{NaCl})$ have prompted a search for an 'environmentally friendly' alternative. However, little research has investigated the potential environmental effects of widespread use of these alternatives.
\end{abstract}

Herein, I detail the results of laboratory tests and field surveys designed to determine the impacts of road salt $(\mathrm{NaCl})$ and other chemical deicers on amphibian communities in Michigan's Upper Peninsula. Using larval amphibians I demonstrate the lethal impacts of a suite of chemical deicers on this sensitive, freshwater species. Larval wood frogs (Lithobates sylvatica) were tolerant of short-term (96 hours) exposure to urea $\left(\mathrm{CH}_{4} \mathrm{~N}_{2} \mathrm{O}\right)$, sodium chloride $(\mathrm{NaCl})$, and magnesium chloride $\left(\mathrm{MgCl}_{2}\right)$. However, these larvae were very sensitive to acetate products $\left(\mathrm{C}_{8} \mathrm{H}_{12} \mathrm{CaMgO}_{8}, \mathrm{CH}_{3} \mathrm{COOK}\right)$ and calcium chloride $\left(\mathrm{CaCl}_{2}\right)$. These differences in tolerance suggest that certain deicers may be more harmful to amphibians than others.

Secondly, I expanded this analysis to include an experiment designed to determine the sublethal effects of chronic exposure to environmentally realistic concentrations of $\mathrm{NaCl}$ on two unique amphibian species, L. sylvatica and green frogs (L. clamitans). L. sylvatica tend to breed in small, ephemeral wetlands and metamorphose within a single season. However, L. clamitans breed primarily in more permanent wetlands and often remain as tadpoles for one year or more. These species employ different life history strategies in this region which may influence their response to chronic $\mathrm{NaCl}$ exposure. Both species demonstrated potentially harmful effects on individual fitness. L. sylvatica larvae had a 
high incidence of edema suggesting the $\mathrm{NaCl}$ exposure was a significant physiologic stressor to these larvae. L. clamitans larvae reduced tail length during their exposure which may affect adult fitness of these individuals.

In order to determine the risk local amphibians face when using these roadside pools, I conducted a survey of the spatial distribution of chloride in the three northernmost counties of Michigan. This area receives a relatively low amount of $\mathrm{NaCl}$ which is confined to state and federal highways. The chloride concentrations in this region were much lower than those in urban systems; however, amphibians breeding in the local area may encounter harmful chloride levels arising from temporal variations in hydroperiods. Spatial variation of chloride levels suggests the road-effect zone for amphibians may be as large as $1000 \mathrm{~m}$ from a salt-treated highway.

Lastly, I performed an analysis of the use of specific conductance to predict chloride concentrations in natural surface water bodies. A number of studies have used this regression to predict chloride concentrations from measurements of specific conductance. This method is often chosen in the place of ion chromatography due to budget and time constraints. However, using a regression method to characterize this relationship does not result in accurate chloride ion concentration estimates. 


\section{Chapter 1: Introduction and Review of the Ecological Effects of Chemical Deicers}

\section{Introduction}

Roads and highways are known to have a substantial impact on the surrounding ecosystem (Trombulak and Frissell 2000, Forman et al. 2002), influencing the ecological processes in an estimated one-fifth of the land area of the United States (Forman 2004). Roads negatively affect animal populations in a number of direct and indirect ways. Directly, wildlife mortality results from road construction and vehicular collisions. The establishment of a road also drastically alters the physical environment, acting as a barrier fragmenting habitat and animal populations. Indirectly, roads are known to modify animal behavior through shifts in home range, changes in movement patterns, alteration of the animal's physiological state, and decreased reproductive success. In addition, roads may facilitate the introduction of non-native species or act as a source of pollutants from vehicles and maintenance activities (Trombulak and Frissell 2000).

Road-based contaminants often have cascading effects through terrestrial and aquatic ecosystems. These contaminants are deposited onto roads primarily through vehicles and road management activities, but may come from diverse sources (Forman et al. 2002). Vehicles contribute a majority of road-based pollutants into the environment, including mineral nutrients, heavy metals, and organic compounds (Gales and VanderMeulen 1992). In addition, management activities such as winter maintenance (e.g., road deicing) and herbicide application contribute a substantial additional amount of pollutants. Of these pollutants, chemicals used in road deicing activities are applied heavily and recognized as a growing threat to ecosystem health (Trombulak and Frissell 2000; Environment Canada 2001; Ramakrishna and Viraraghavan 2005).

In cold climates, safe winter driving relies on the application of chemical products to remove and prevent snow and ice from adhering to road surfaces. Since the 1930s, the most common de-icing product used on roads in the United States is sodium chloride 
( $\mathrm{NaCl}$; henceforth, road salt) due to its low cost and widespread availability. In North America, an estimated 10 million tons of road salt is used each year in the United States (D’Itri 1992), ranging from 0.3 to 17.6 tons per lane mile across 26 states (National Research Council 1991), with an estimated 4.7 million tons used annually in Canada (Environment Canada 2001). When road salt mixes with water on a paved surface, it separates into its sodium and chloride ions to form a brine solution. This solution has a lower freezing point than pure water and penetrates through the ice and snow to prevent ice from bonding to the pavement surface (Gales and VanderMeulen 1992).

In addition to road salt, a number of different chemicals may be used or added to aid in the deicing process. For example, inorganic salts may also be used separately or in conjunction with road salt (e.g., $\mathrm{CaCl}_{2}, \mathrm{MgCl}_{2}$, and $\mathrm{KCl}$; Environment Canada 2001). Abrasives such as sand, dirt, and cinder are frequently added to road salt to increase friction between tires and the pavement surface (Jones et al. 1992). Maintenance often requires the addition of anti-caking agents, such as sodium ferrocyanide (Paschka et al. 1999), cyanide (Oberts 1986), chromium, and ferric ferrocyanide (Gales and VanderMeulen 1992). Because salt corrodes airplane components, deicing of airplanes is performed using large quantities of urea in Canada (Hassan et al. 2002) and different forms of glycol in the United States (D'Itri 1992; Ramakrishna and Viraraghavan 2005). Much like road salt, these materials often contain additional contaminants and adhesives such as ethylene oxide, dioxane, acetaldehyde, and rust inhibitors (Hassan et al. 2002).

Environmental contamination by road salt depends greatly on the amount used and the method of application. Road salt may enter the environment through the following methods (Burtwell 2001; reviewed in Forman 2004):

1. Traditional salting practices in which salt lands onto or bounces from the road onto the roadside vegetation;

2. By being splashed of thrown off to the roadside through the action of passing vehicle traffic;

3. The runoff of salt from roads directly into natural drainage systems; 
4. The spraying of dissolved salt on roadside soil, vegetation, and surface waters by passing traffic;

5. By salted snow being blown or plowed onto the roadside by snowplows;

6. The leaching of salt from uncovered stockpiles;

7. The runoff from post-operational wash-down procedures of winter salting vehicles.

Apart from the direct costs of purchasing and applying road salt, there are a number of indirect costs associated with winter maintenance activities. Salt, when mixed with water, has a strong tendency to increase rusting of most ferrous based metals. This may cause corrosion of the reinforcing rebar in bridges and highways, as well as damage to motor vehicle materials (D'Itri 1992). In addition, road salt is known to cause a number of deleterious effects on road surfaces and environmental damage (Forman 2004; Ramakrishna and Viraraghavan 2005). Considering these indirect costs, separate studies estimated that the real cost of applying road salt is anywhere from $\$ 35$ to $\$ 57$ dollars in damage per dollar spent purchasing road salt (D'Itri 1992; Forman 2004). This negative economic impact of road salt application suggests that alternative solutions are warranted.

Of the indirect costs of road salt contamination, environmental damage is the most concerning. Environmental damage from road salt is particularly harmful due to the cumulative properties of chloride. Depending on its application, road salt may be contained at the road edge or transported far from its source. After initial application, the salt is temporarily contained within the interface between the soil surface and groundwater. Here the ions, namely sodium, are likely absorbed by roadside vegetation (Lunmark and Olofsson 2007). Sodium ions are typically involved in the chemical processes of the soil, whereas chloride is greatly conserved. Once deposited, chloride ions from these salts remain in the ecosystem in ground and surface waters (Environment Canada 2001).

With the intensive and widespread application of road salt on an annual basis over the past 60 years, it is not surprising that an increase in sodium and chloride concentrations in ground and surface waters is well documented (Williams et al. 2000; Benbow and Merritt 
2004; reviewed in Ramakrishna and Viraraghavan 2005). Anthropogenic sources of $\mathrm{NaCl}$ have been shown to negatively affect ground and surface water quality at a number of sites in North America (Hoffman et al. 1981; Forman and Alexander 1998; Environment Canada 2001; Godwin et al. 2003). Road salt contamination also affects human health and population growth. Road salt contamination of drinking water sources is considered a serious threat to human health (Calabrese and Tuthill 1979), mainly through the development of hypertension (reviewed in Jones et al. 1992). In light of road salt as a threat to human health and its adverse impacts on the aquatic environment, Environment Canada identified road deicing chemicals as toxic (Environment Canada 2001). This designation prompted a new sense of urgency among scientists and mangers to consider alternate deicing chemicals. In addition, road salt contamination is viewed as a constraint on urban growth in North America (Howard and Maier 2006). As population growth and urban sprawl contribute to an increasing mileage of road surfaces each year, the contamination from road salt and its associated pollutants are a major threat to the Earth's ecosystem. Understanding the effects of chemical deicers on freshwater and aquatic ecosystems will aid in the conservation of these important natural resources.

The goal of this paper is to examine the literature regarding the effects of chemical deicers on aquatic and terrestrial ecosystems. The physical, chemical, and biological impacts of common deicing products are discussed. In addition, alternatives to road salt are reviewed in terms of their level of environmental contamination.

\section{Impacts on Surface and Ground Waters}

Contamination of ground and surface waters by chemical deicers poses a major threat to freshwater ecosystems. The level of contamination is dependent on a number of spatial and temporal variables, including the area of treated roadway that drains to the water body, the frequency and rate of application of the deicer, the route of transport from the roadway to the water body, the extent of biodegradation along the route (McFarland and O'Reilly 1992), road and soil characteristics, type and amount of precipitation, and wind conditions (Blomqvist 1999; Lunmark and Olofsson 2007). Temporal variation of 
chloride levels in surface waters is well-documented and depends on temperature and precipitation. Increasing temperatures in the spring are coupled with high chloride levels in surface water during the snowmelt, a result of the mobility of road deicers in contaminated soil and/or groundwater sources (Jones et al. 1992). Surface waters close to roads, or those that receive runoff from salted roads (i.e., via ditches and drainage systems), are at a greater risk of receiving road-based pollutants.

Groundwater supplies are most impacted by road salt contamination as the majority of road salt eventually reaches groundwater aquifers. Precipitation plays a large role in chloride transportation into the groundwater in mobilizing the ions in soil and surface waters (Fostad and Pedersen 1996; Pedersen et al. 2000; Lunmark and Olofsson 2007). Chloride may then accumulate in groundwater supplies as it is conserved during migration through soil and surface waters (Kincaid and Findlay 2009). Chloride accumulation in groundwater is irreversible, posing a threat to human health and sustainability.

The primary impact of road salt contamination is increased chloride or salinity levels. Surface waters may experience temporal fluctuations in salinity, however, these fluctuations are generally short term. Natural salinity of surface waters is a result of rock runoff from the drainage basin, atmospheric precipitation, and the balances between evaporation and precipitation (reviewed in Jones et al. 1992). Contributions from industrial sources, chemical deicers, and municipal waters may elevate chloride concentrations in surface waters. The level of road salt contamination in surface waters depends largely on the road drainage system, topography, discharge of the receiving stream, the degree of urbanization of the watershed, temperature, and precipitation (Scott et al. 1986).

Along with increased salinity, the secondary impacts of road salt contamination in surface waters can have grave impacts on the aquatic community. These include salt stimulation of algal growth, changes in density gradients, salt induced stratification, (reviewed in Ramakrishna and Viraraghavan 2005), and mobilization of heavy metals 
from lake bottom sediments (Jones et al. 1992). Trace elements in road salt may leach into nearby water systems relieving the nutrient limitations for algae growth. This may further cause salt-induced stratification that prevent mixing and attribute to anoxic benthic conditions (Judd 1970; Hoffman et al. 1981; Benbow and Merritt 2004). Water run-off containing high density of salts may accumulate at the bottom of the lake, preventing the usual spring overturn (Jones et al. 1992). Without this essential annual mixing occurring, oxygen and nutrients within a lake are not distributed, making these important nutrients unavailable to aquatic organisms. This effect was observed in a study along a stretch of interstate in the Adirondack region of New York. Demers and Sage (1990) sampled chloride levels downstream of a heavily salted section of road, observing a dramatic increase in chloride concentrations up to 50 meters from the roadside. These streams carrying this dense contaminated water flowed into a nearby lake, forming a chemocline in the lake. The same road salt contamination induced chemocline was also observed in First Sister Lake, Michigan (Judd and Stegall 1982). In addition to chemoclines, changes in $\mathrm{pH}$ may mobilize heavy metals contained within lake-bottom sediments. Mercury contamination is known to occur in waters that experience high levels of road salt or $\mathrm{pH}$ fluctuations (Jones et al. 1992). Thus, although the salinity fluctuations in surface waters may be short-lived, these secondary effects can have longterm impacts on the freshwater ecosystem.

\section{Modification of Soils}

The initial impacts of road salt on soil may allow for greater distribution to surrounding water bodies as increased levels of sodium and chloride modify the structure of roadside soils. Sodium causes deflocculation in the soil leading to a loss of structure, making less air and water available for plant growth. Sodium ions may also exchange with nutrient ions such as calcium and magnesium, thereby reducing soil fertility (Burtwell 2001). The alteration of soil structure may also impact the degree of contamination from roadside runoff. More solid soils, such as those present during a frost, will be impermeable to water runoff. This would allow for greater mobility of the road salt contamination away from the road through transport by surface water (Fritzsche 1992; Lundmark and Olofsson 2007) and may be irreversible. 


\section{Impacts on Vegetation}

Increased salt levels may drastically impact vegetation, though the severity of the damage depends in part on the method of salt application (Sucoff et al. 1976; Bryson and Barker 2002). Salt directly enters plants principally through spray to the foliage and absorption from the soil by root uptake (Jones et al. 1992). Deicing salt may accumulate on roadside vegetation, causing the browning of leaves and needles of trees through a salt burn (reviewed in Viskari and Karenlampi 2000). Salt damage to plants depends partly on the salinity of the soil and tolerance level of the species (Fostad and Pedersen 2000).

Indirect effects of roadside vegetation exposed to high levels of sodium chloride include increased susceptibility to disease and pests (Viskari and Karenlampi 2000), a loss of cold hardiness (Sucoff et al. 1976), and a reduction in competitive ability (Jones et al. 1992). In addition, saline soils may cause period of osmotic stress, in which the plant loses moisture into the surrounding soil. Destruction of soil structure following sodium deposition, as discussed above, may decrease the overall health of the associated plants (Hootman and Kelsey 1992).

The death of roadside vegetation may have greater implications for the localized road salt contamination of nearby surface waters. Roadside vegetation is important in preventing erosion of roadside soils, and likely acts as a buffer in absorbing contaminants. The removal of this vegetation would allow for greater mobility of both road salt and sediments into nearby surface waters. Increased sedimentation in freshwater systems is known to reduce habitat availability for fish (Newcombe and McDonald 1991) and amphibian species (Welsh and Olivier 1998).

Elevated salinity levels in surface waters, whether short or long-term, can have a drastic impact on the flora of the freshwater system. Salinity tolerance varies widely among plant species. Increases in salinity can affect plant growth by increased water stress in the root medium, the accumulation of ions or toxins in the soil, and/or the accumulation of ions in the plant tissue (reviewed in Howard and Mendelssohn 1999). Increased salinity levels 
may also affect community composition either directly, through toxicity or osmotic effects, or indirectly through interspecific competition (reviewed in Miklovic and Galatowitsch 2005). This is particularly important in vegetative communities, where road salt may significantly affect seedling development and/or interspecific competition. With increasing salinity levels, diversity and species richness in freshwater wetlands decreased (Wilcox 1986; Panno et al. 1999; Latham et al. 1991; Miklovic and Galatowitsch 2005), seedling germination and survival decreased (Pearson et al. 1966; Zedler et al. 1990), and the biomass of the wetland communities decreased (Isabelle et al. 1987; McKee and Mendelssohn 1989). Excess salt in the roadside environment may also alter the vegetative community helping to facilitate the establishment of invasive species (e.g., Phragmites; Richberg et al. 2001). Runoff from uncovered, road salt storage piles has been directly linked to shifts in the plant community in which salt-sensitive species were replaced by salt tolerant species. In this setting, population shifts are likely to occur towards less desirable, non-native salt-tolerant species (Gales and VanderMeulen 1992).

\section{Impacts on Terrestrial and Aquatic Wildlife}

Plants and animals have an acute ability to respond to temporary changes in $\mathrm{pH}$ and acidity. Certain species of plants and animals are better adapted to saline environments than others (Freda 1991). However, when exposed to levels beyond their tolerance level, mortality may occur. Aquatic species are likely to be most impacted by road salt contamination through disruption of osmotic regulation. While many aquatic organisms are sensitive to salinity changes (e.g., invertebrates and fish), most freshwater bacteria and blue-green algae are less tolerant (Jones et al. 1992).

\section{Invertebrates}

Aquatic invertebrates may also be directly and indirectly affected by increases in environmental salt levels. Aquatic invertebrates are sensitive to changes in chloride levels (Demers and Sage 1990; Bridgeman et al. 2000; Benbow and Merritt 2004) as chloride ions are known to compromise osmoregulatory processes in aquatic insects (Sutcliffe 1961; Blasius and Merritt 2002). The sensitivity of certain aquatic insects to high levels of chloride threatens the community structure of wetland ecosystems (Benbow and 
Merritt 2004). In a study on four streams in the Adirondack region of New York, Demers and Sage (1990) observed a significant decrease in the diversity of aquatic insects inhabiting artificial substrates downstream of a heavily salted section of a highway. Molles (1980) observed stream insects indirectly affected by road salt application following the death of roadside vegetation. Sedimentation loads in the rivers increased as a result, causing a reduction in invertebrate abundance and biomass. Increased sedimentation and the loss of aquatic insects as an important food source may drastically impact ecosystem integrity.

\section{Mammals and Birds}

During winter, many animals are attracted to natural and artificial salt deposits to satisfy a dietary need when food sources may be scarce. In Wisconsin, a number of small animals suffered mortality from salt poisoning during a hard winter of freezing temperatures and high snowfall. Trainer and Karstad (1960) observed wild rabbits, pheasants, quail, and pigeons exhibiting behavioral abnormalities arising from distress of the central nervous system from ingesting road salt prior to mortality.

The attraction to roadside sources of salt also poses a problem for larger mammals. In turn, human safety may be in danger from vehicle collisions when large mammals are attracted to roads and highways. In Canada, a study conducted by Fraser and Thomas (1982) examined the relationship between the salt content of roadside pools and the frequency of moose collisions along a stretch of highway. Fraser and Thomas (1982) found that moose concentrated around roadside pools with high levels of sodium and chloride. More than half of the moose-vehicle collisions on this stretch of highway were at or adjacent to these salty pools. In an effort to decrease the potential for moose-vehicle collisions, the Quebec Ministry of Transportation filled and drained these salty pools. LeBlond et al. (2007) documented a decrease in the number of moose visiting roadside pools after management was initiated.

Avian species are also attracted to roadside sources of salt putting them in danger of direct mortality from vehicle collisions (Schulkin 1991). Accidental ingestion may occur 
when birds forage at the roadside in search of grit to aid in digestion. House sparrows, for example, are known to choose dietary grit with the same physical characteristics as road salt (Gionfriddo and Best 1995; Bollinger et al. 2005). This species demonstrated abnormal behavior, including depression, ataxia, inability to fly or perch, and death in as little as 45 minutes when consuming large doses of road salt (Bollinger et al. 2005). Behavioral changes associated with road salt toxicity, such as ataxia and the inability to fly, put birds at a greater risk of vehicular mortality.

In a recent review on birds, Mineau and Brownlee (2005) concluded that road salt is a major mortality factor. Their review included 12 published reports of bird kills associated with road salt, encompassing eight species. Birds that are readily observed ingesting road salt exhibit unusual behavior, appearing fearless and are easily approached, increasing their vulnerability to car strike. In all but one case the primary cause of poisoning was identified as sodium chloride, with calcium chloride (a popular road salt alternative) cited in the twelfth report.

\section{Amphibians}

The effect of road salt contamination on amphibians is also briefly studied (e.g., Turtle 2000; Dougherty and Smith 2006; Sanzo and Hecnar 2006; Karraker 2007a,b).

Amphibians are likely to be drastically effected by road salt contamination due to their explosive breeding at the peak of spring contamination, and breeding in small, ephemeral pools where salts are likely to be concentrated (Karraker 2007a). The by-products of road salt contamination, namely mercury contamination and low $\mathrm{pH}$ levels, are known to disrupt the osmotic balance in the membranes surrounding amphibian embryos, halting or impairing development (Freda 1991). Amphibians may also be greatly affected by the indirect effects of road salt pollution. As mentioned above, pollution from road salt may release heavy metals from lake-bottom sediments (Jones et al. 1992). The disruption or depletion of aquatic insect communities will greatly impact amphibians, due to their dependence on these organisms as a major food source. Amphibians are very dependent on water throughout their life cycle and will thus be consistently exposed to contaminants present in the water. 
Herpetofaunal communities, which rely heavily on temporary and permanent sources of freshwater, are likely affected by road salt contamination. Turtle (2000) did not find evidence of localized adaptation to road salt by Ambystoma maculatum inhabiting roadside vernal pools. In comparing the tolerance levels of road salt on different amphibians, Karraker (2007a,b) observed distinct variations between species. Rana (Lithobates) clamitans tadpoles were found to be insensitive to low to moderate road salt contamination, while $R$. sylvatica tadpoles and $A$. maculatum larvae were negatively impacted (Karraker 2007a,b; Sanzo and Hecnar 2006). This has important implications for inter-specific competition, giving $R$. clamitans an advantage in the use of waters with higher salinity levels. To my knowledge, the community effect of increased salinization has not been studied in other vertebrates.

\section{Alternatives to Road Salt}

Due to the known negative environmental impacts and corrosive properties of $\mathrm{NaCl}$, numerous alternatives are currently being developed to improve de-icing operations and limit the use of rock salt. State and municipal transportation agencies are evaluating these alternatives in an effort to maintain safe winter driving conditions while lessening environmental degradation (D'Itri 1992). The performance of these alternatives to traffic and environmental trials are reviewed in the following paragraphs.

Abrasives such as sand and cinders are thought to be a viable alternative to road salt in maintaining the safety of winter roads. The use of abrasives is an attractive alternative due to its low cost relative to road salt at over four times less expensive (Gales and VanderMeulen 1992). However, the application of vast quantities of these materials raises a number of environmental concerns. Primarily, highway runoff containing these materials will increase the sediment load in lakes and streams, hereby lowering the water quality and smothering roadside vegetation (Gales and VanderMeulen 1992).

A popular chemical alternative to road salt is calcium magnesium acetate, henceforth CMA. According to modeling efforts, the impacts of CMA on surface waters are believed 
to be less than that of road salt (McFarland and O'Reilly 1992). Both calcium and magnesium ions are less mobile, tend to precipitate in water, and are thus less threatening in groundwater contamination (Bang and Johnston 1998). However, water hardness issues may occur through increasing concentrations of calcium and magnesium. CMA may also lower the amount of dissolved oxygen in surface water bodies, posing a problem for aquatic organisms. CMA is known to decrease algal and periphyton biomass in freshwater systems, while remaining relatively harmless in toxicity tests on invertebrates and fish (McFarland and O'Reilly 1992). Other studies noted a lack of significant changes in phytoplankton and bacterial communities in freshwater lakes following CMA contamination (Goldman et al. 1992). In soils, CMA may be beneficial in contributing nutrients (calcium and magnesium) and improving soil structure by increasing water and air movement (Gales and VanderMeulen 1992). Field trials indicated that direct application of CMA solutions did not affect the growth, foliage, strength, or rooting of plant seedlings or tree saplings (Horner 1988).

The Nevada Department of Transportation (NDOT) and the California Department of Transportation (CALTRANS) performed a detailed field and laboratory investigation comparing the effectiveness of CMA as a substitute for sodium chloride (Harris et al. 1993). The study found that CMA behaved differently as a deicer than rock salt, limiting its effectiveness in different combinations of road and atmospheric conditions. In addition, the chemical and physical properties of CMA made it difficult to handle and transport (Harris et al. 1993). While CMA does perform well in deicing roadways, its high cost (over twenty times more expensive than salt) may limit widespread implementation (D’Itri 1992).

Another popular alternative to road salt is calcium chloride, or $\mathrm{CaCl}_{2}$. Calcium chloride acts similarly to road salt in de-icing operations, and it is able to work effectively at lower temperatures than salt. Approximately 0.3 million tons of $\mathrm{CaCl}_{2}$ are used in North America each year. Calcium chloride is thought to be less harmful to the environment than sodium chloride, and calcium poses no known health threat in drinking water (Gales and VanderMeulen 1992). Research on trees has shown that by increasing Ca 
concentrations, the effects of $\mathrm{NaCl}$ may be reduced. In studying spruce trees, Bogemans et al. (1989) found that substituting 20 to $30 \%$ of $\mathrm{CaCl}_{2}$ for $\mathrm{NaCl}$ resulted in a $50 \%$ decrease of $\mathrm{Na}$ in the needles. However valuable as an alternative, its high cost (over eight times that of road salt) may greatly limit its use (Gales and VanderMeulen 1992).

Other alternatives to road salt include, sodium formate $\left(\mathrm{CHNaO}_{2}\right)$, magnesium acetate $\left(\mathrm{C}_{4} \mathrm{H}_{6} \mathrm{MgO}_{4}\right)$, calcium acetate $\left(\mathrm{C}_{4} \mathrm{H}_{6} \mathrm{CaO}_{4}\right)$, glycol liquids, urea $\left(\mathrm{CH}_{4} \mathrm{~N}_{2} \mathrm{O}\right)$, corrosion inhibiting salts (Gales and VanderMeulen 1992), methanol $\left(\mathrm{CH}_{3} \mathrm{OH}\right.$; Dougherty and Smith 2006), tetra potassium pyrophosphate (Gutiw 1998; Ramakrishna and Viraraghavan 2005) and Ice Shear ${ }^{\mathrm{TM}}$ (an equimolar mixture of sodium acetate and sodium formate; Bang and Johnson 1998). Of these, Ice Shear ${ }^{\mathrm{TM}}$ was found to be a viable alternative to road salt. Using a mixture of biochemical oxygen demand (BOD), chemical oxygen demand (COD), acute rainbow trout bioassays, and phytotoxicity tests on typical roadside vegetation, Ice Shear ${ }^{\mathrm{TM}}$ was shown to have minimal environmental disturbance in both aquatic and terrestrial ecosystems (Bang and Johnston 1998). However, Bang and Johnston did not address the impact of CMA on sensitive members of freshwater ecosystems. This information is crucial to understand before this deicer is recommended for widespread use.

\section{Conclusions and Research Scope}

Road deicing activities have cascading impacts on the surrounding terrestrial and aquatic ecosystems. The cumulative environmental damage from deicing activities is only now being realized, particularly as they threaten human health and population growth. The direct and indirect environmental impacts of chemical deicers on water sources, soils, vegetation, and wildlife should be considered a serious threat to ecosystem health. In light of the known environmental impacts of road salt contamination to aquatic and terrestrial ecosystems, a full understanding of the impacts of these alternatives is warranted prior to widespread application. Considerations of alternatives to road salt will likely gain in popularity as the negative impacts of road salt are more widely recognized. 
At present, few alternatives are being implemented due to high cost and little incentive. However, cost as a limiting factor in application of alternative deicers may be less of a problem when the widespread impacts of intensive road salt application are considered. Confounded in this is the lack of knowledge concerning the behavior of these alternative deicing chemicals in the terrestrial and aquatic ecosystems. Deicing alternatives to road salt should be thoroughly investigated as to their impacts on the terrestrial and aquatic ecosystems, namely their effect on flora and fauna. In addition to chemical alternatives, management activities should aim to alter deicing practices. This may include limiting the amount of deicing chemicals that are applied to roadways (e.g., Pollock 1992) and/or identifying areas adjacent to highways of high environmental concern. Sensible deicing practices would greatly help to lessen the long-term impacts. As new roads are being added to the North American highway network each year, awareness of their potential environmental damage should evoke careful forethought in transportation planning.

Although previous research has addressed a number of questions concerning the ecological effects of road salt and road salt alternatives, we are left with many unanswered questions regarding this impact. For example, do sensitive organisms such as amphibians respond differently to one type of chemical deicers over another? In addition, we have knowledge of the lethal impacts of road salt exposure on a few populations of amphibians yet further analysis with different species and/or populations will help to determine the potential for local adaptation to road salt runoff. Furthermore, investigations into amount and spatial distribution of residual chloride from road salt $(\mathrm{NaCl})$ application will help us to better understand the environmental impacts of its use in areas where application rates may be variable.

To address these research needs, I employed a mixture of laboratory, field, and geographical tools in the following chapters. Firstly, in Chapter 2, I examined the lethal response of local wood frog (Lithobates sylvatica) larvae to exposure to six chemical deicers in acute toxicity experiments. This analysis provided estimates of the lethal effects of six commonly used chemical deicers on a local population of wood frogs. The endpoint of this experiment is the estimation of the median lethal concentration or $\mathrm{LC}_{50}$, a 
measure of the effects of short term (96 hours) exposure on the survival of larval amphibians. These estimates are invaluable in that they allow for a direct comparison of the effects of this suite of chemical deicing products within a population. In addition, these estimates may be used to evaluate the potential risks amphibians using roadside habitats may encounter when attempting to breed in these water bodies.

Next, I built upon the knowledge gained through the acute toxicity tests by further examining the response of the larvae of two unique amphibians, wood frogs (L. sylvatica) and green frogs (L. clamitans), to long term ( $>90$ days) exposure to low levels of $\mathrm{NaCl}$ in Chapter 3. This chronic toxicity approach allows for identification of the sublethal or developmental effects of this exposure that may have negative impacts on the fitness of these individuals. In using these two species, I was able to gain insight into the potential community level effects of this exposure on species that employ different life history strategies.

In Chapter 4, I characterize the environmental impacts of $\mathrm{NaCl}$ application in the three northernmost counties of Michigan in an effort to determine the risk local amphibians may face when using roadside water bodies in this area. I conducted a broad scale survey of water bodies both near and farther from the main arterial highway in this region, US 41 , to determine the concentration and temporal variation in chloride. I used this data to spatially estimate the presence of a road salt effect zone in this region. This knowledge is important in that transportation managers may use this information to alter their application of $\mathrm{NaCl}$ so as to limit $\mathrm{NaCl}$ runoff in roadside water bodies. Finally, in Chapter 5, I address an issue in estimating chloride concentration from conductivity measurements. A number of researchers have used this method as an alternative to expensive and time consuming analytical chemistry, however, the methodology behind these estimates prohibits this calculation. 


\section{References}

Bang SS, Johnston D. 1998. Environment effects of sodium acetate/formate deicer, Ice Shear $^{\mathrm{TM}}$. Archives of Environmental Contamination and Toxicology. 35:580-587.

Benbow ME, Merritt RW. 2004. Road-salt toxicity of select Michigan wetland macroinvertebrates under different testing conditions. Wetlands. 24:68-76.

Blasius BJ, Merrit RW. 2002. Field and laboratory investigations on the effects of road salt $(\mathrm{NaCl})$ on stream macroinvertebrate communities. Environmental Pollution. 120:21931.

Blomqvist G. 1999. Air-borne transport of de-icing salt and damage to pine and spruce trees in a roadside environment. Division of Land and Water Resources, Department of Civil and Environmental Engineering, Royal Institute of Technology, Stockholm.

Bogemans J, Nierinck L, Stassart JM. 1989. Effect of deicing chloride salts on ion accumulation in spruce (Picea abies (L.) sp.). Plant and Soil. 113:3-11.

Bollinger TK, Mineau O, Wickstrom ML. 2005. Toxicity of Sodium Chloride to House Sparrows (Passer domesticus). Journal of Wildlife Diseases. 41:363-370.

Bridgeman TB, Wallace CD, Carter GS, Carvajal R, Schiesari LC, Aslam S, Cloyd E, Elder E, Field A, Schulz KL, Yurista PM, Kling GW. 2000. A limnological survey of Third Sister Lake, Michigan with historical comparisons. Journal of Lake and Reservoir Management. 16:253-267.

Bryson GM, Barker AV. 2002. Sodium accumulation in soils and plants along Massachusetts Roadsides. Community Soil Science Plant Annuals. 33:67-78. 
Burtwell M. 2001. Assessment of the performance of pre-wetted salt for snow removal and ice control. Transportation Research Record 1741, Paper No. S00-0052. Berkshire, United Kingdom.

Calabrese EJ, Tuthill RW. 1979. Elevated sodium levels in the public drinking water as a contributor to elevated blood pressure levels in the community. Archives of Environmental Health. 34:197-203.

D'Itri FM. Prologue. In: D'Itri FM, ed. Chemical Deicers and the Environment. 1st ed. Boca Raton (FL): Lewis Publishers. 1992. p. v-x.

Demers, C. and R.Sage. 1990. Effects of road deicing salts on chloride levels in four Adirondack. streams. Water, Air and Soil Pollution. 49: 369-373.

Dougherty, C. K. and G. R. Smith. 2006. Acute effects of road de-icers on the tadpoles of three anurans. Applied Herpetology 3: 87-93.

Environment Canada. 2001. Priority Substances List Assessment Report for Road Salts. Environment Canada, Catalog number En40-215/63E. Ottawa, Ontario, Canada.

Forman R, Alexander L. 1998. Roads and their major ecological effects. Annual Review of Ecology and Systematics 29:207-31.

Forman RTT, Reineking B, Hersperger AM. 2002. Road traffic and nearby grassland bird patterns in a suburbanizing landscape. Environmental Management. 29: 782-800.

Forman RTT. 2004. Road ecology's promise: What's around the bend? Environment. $46: 8-21$.

Fostad O, Pedersen PA. 2000. Container-grown tree seedling responses to sodium chloride application in different substrates. Environmental Pollution. 109:203-210. 
Fraser D, Thomas ER. 1982. Moose-vehicle accidents in Ontario: relation to highway salt. Wildlife Society Bulletin. 10:261-265.

Freda J. 1991. The effects of aluminum and other metals on amphibians. Environmental Pollution. 71:305-328.

Fritzsche CJ. 1992. Calcium magnesium acetate deicer. Water Environment and Technology. 4: 44-51.

Gales JE, VanderMeulen J. 1992. De-icing Chemical Use on the Michigan State Highway System. In: D'Itri FM, ed. Chemical Deicers and the Environment. 1st ed. Boca Raton (FL): Lewis Publishers. 1992. p. 135-184.

Gionfriddo JP, Best LB. 1995. Grit use by house sparrows: Effects of diet and grit size. Condor. 97: 57-67.

Godwin KS, Hafner SD, Buff MF. 2003. Long-term trends in sodium and chloride in the Mohawk River, New York: the effect of fifty years of road-salt application.

Environmental Pollution. 124:273-281.

Goldman CR, Lubnow FS, Elser JJ. 1992. Environmental effects of calcium magnesium acetate on natural phytoplankton and bacterial communities in northern California lakes. In: D'Itri FM, ed. Chemical Deicers and the Environment. 1st ed. Boca Raton (FL): Lewis Publishers. 1992. p. 229-244.

Gutiw 1998 Gutiw PL. 1998. Roadside salinity changes by pavement deicer application on a Saskatchewan highway. M.S.thesis, Environmental Systems Engineering Department, University of Regina, Regina, Saskatchewan. 
Harris GP, Turner R, Nelson RJ. 1993. Field test comparison of calcium magnesium acetate to salt. Journal of Transportation Engineering. 119:889-905.

Hassan Y, Abd El Halim AO, Razaqpur AG, Bekheet W, Farha MH.2002. Effects of runway deicers on pavement materials and mixes: comparison with road salt. Journal of Transportation Engineering. 128 :385-391.

Hoffman RW, Goldman CR, Paulson S, Winters GR. 1981. Aquatic impacts of deicing salts in the central Sierra Nevada Mountains, California. Water Resources Bulletin. 17:280-285.

Horner R.1998. NCHRP Report 305: Environmental Monitoring and Evaluation of Calcium Magnesium Acetate (CMA). National Research Council.

Howard WF, Maier H. 2006. Road De-Icing Salt as a Potential Constraint on Urban Growth in the Greater Toronto Area, Canada. Journal of Contaminant Hydrology. 91:146-170.

Howard RJ, Mendelssohn IA. 1999. Salinity as a constraint on growth of oligohaline marsh macrophytes. I. Species variation in stress tolerance. American Journal of Botany. 86:785-794.

Isabelle PS, Fooks LJ, Keddy PA, Wilson SD. 1987. Effects of roadside snowmelt on wetland vegetation: An experimental study. Journal of Environmental Management. 25:57-60.

Jones PH, Jeffery BA, Walter PK, Hutchon H. 1992. Environmental Impact of Road Salting. In: D'Itri FM, ed. Chemical Deicers and the Environment. 1st ed. Boca Raton (FL): Lewis Publishers. 1992. p. 1-116. 
Judd J. 1970. Lake stratification caused by runoff from street deicing. University of Wisconsin- Milwaukee, Center for Great Lakes Studies. 4:521-532.

Judd JH, Stegall JW. 1982. Reevaluation of the effects of deicing salt runoff on a small lake. National Technical Information Service, Springfield, Virginia.

Karraker NE. 2007a. Are embryonic and larval green frogs (Rana clamitans) insensitive to road deicing salt? Herpetological Conservation and Biology 21:35-41.

Karraker NE. 2007b. Investigation of the amphibian decline phenomenon: Novel smallscale factors and a large-scale overview. Ph.D. dissertation, State University of New York, College of Environmental Science and Forestry, Syracuse, New York.

Hootman RG, Kelsey PD. 1992. Woody Plants and Roadway Salt: An Urban Dilemma.The Morton Arboretum Quarterly 28:44-48.

Kincaid DW, Findlay SEG. 2009. Sources of elevated chloride in local streams: Groundwater and soils as potential reservoirs. Water, Air, and Soil Pollution. 203:335342.

Latham PJ, Pearlstine LG, Kitchens WM. 1991. Spatial distributions of the softstem bulrush, Scirpus robustus validus, across a salinity gradient. Estuaries. 14:192198.

Leblond M, Dussault C, Ouellet JP, Poulin M, Courtois R, Fortin J. 2007. Management of roadside salt pools to reduce moose-vehicle collisions. Journal of Wildlife Management. 71:2304-2310.

Lundmark A, Olofsson B. 2007. Chloride deposition and distribution in soils along a deiced highway - assessment using different methods of measurment. Water, Air and Soil Pollution. 182:173-185. 
McFarland BL, O’ Reilly KT. 1992. Environmental impact and toxicological characteristics of calcium magnesium acetate. In: D'Itri FM, ed. Chemical Deicers and the Environment. 1st ed. Boca Raton (FL): Lewis Publishers. 1992. p. 194-227.

McKee KL, Mendelssohn IA. 1989.Response of a freshwater marsh plant community to increased salinity and increased water level. Aquatic Botany. 34:301-316.

Miklovic LG, Galatowitsch SM. 2005. Effects of $\mathrm{NaCl}$ and Typha angustifolia on marsh community establishment: a greenhouse study. Wetlands. 25: 420-429.

Mineau P, Brownlee L. 2005. Road salts and wildlife - An assessment of the risk with particular emphasis on winter finch mortality. Wildlife Society Bulletin. 33: 835-841.

Molles MC. 1980. Effects of Road Salting on Stream Invertebrate Communities, USDA Forest Service, Eisenhower Consortium Bulletin, 1980.

National Research Council, Transportation Research Board. 1991. Highway Deicing: Comparing Salt and Calcium Magnesium Acetate. Special Report 235. www.nas.edu/trb/publications/sr235.html.

Newcombe CP, MacDonald DD. 1991. Effects of suspended sediments on aquatic ecosystems. North American Journal of Fisheries Management. 11: 72-82.

Oberts GL. 1986. Pollutants associated with sand and salt applied to roads in Minnesota. Water Resources Bulletin. 22:479-483.

Panno SV, Nuzzo VA, Cartwright K, Hensel BR, Krapac IG. 1999. Impact of urban development on the chemical composition of groundwater in a fen-wetland complex. Wetlands. 19:1. 
Paschka MG, Ghosh RS, Dzombak DA. 1999. Potential water-quality effects from iron cyanide anticaking agents in road salt. Water Environment Research. 6:12351239.

Pearson GA, Ayers AD, Eberhard DL. 1966. Relative salt tolerance of rice during germination and early seedling development. Soil Science. 102:151-156.

Pedersen LB, Randrup TB, Ingerslev M. 2000. Effects of road distance and protective measures on deicing $\mathrm{NaCl}$ deposition and soil solution chemistry in planted median strips. Journal of Arboriculture. 26:238-245.

Pollock SJ. 1992. Remediating highway deicing salt contamination of public and private water supplies in Massachusetts. In: D'Itri FM, ed. Chemical Deicers and the Environment. 1st ed. Boca Raton (FL): Lewis Publishers. 1992. p. 519-538.

Ramakrishna D, Viraraghavan T. 2005. Environmental impact of chemical deicers- a review. Water, Air, and Soil Pollution. 166:49-63.

Richburg J, Patterson III JA, Lovenstein F. 2001. Effects of Road Salt and Phragmites australis invasion on the vegetation of a western Massachusetts calcareous lake-basin fen. Wetlands. 21:247-255.

Sanzo D, Hecnar SJ. 2006. Effects of road de-icing salt $(\mathrm{NaCl})$ on larval wood frogs (Rana sylvatica). Environmental Pollution 140:247-256.

Schulkin J. 1991. Sodium Hunger: The Search for a Salty Taste. Cambridge University Press. New York, New York.

Scott JB, Steward CR, Stober QJ. 1986. Effects of urban development on fish population dynamics in Kelsey Creek, Washington. Transactions of the American Fisheries Society. 115:555-567. 
Sucoff E, Hong SG, Wood A. 1976. NaCl and twig dieback along highways and cold hardiness of highway versus garden twigs. Canadian Journal of Botany. 54:2268-2271.

Sutcliffe DW. 1961. Studies on salt and water balance in caddis larvae (Trichoptera): I. Osmotic and ionic regulation of body fluids in Limnephilus affinis Curtis. Journal of Experimental Biology. 38:501-519.

Trainer DO, Karstad L. 1960. Salt poisoning in Wisconsin wildlife. Journal of the American Veterinarian Medical Association. 13: 614-617.

Trombulak SC, Frissell CA. 2000. Review of ecological effects of roads on terrestrial and aquatic communities. Conservation Biology. 14:18-30.

Turtle SL. 2000. Embryonic survivorship of the spotted salamander (Ambystoma maculatum) in roadside and woodland vernal pools in southeastern New Hampshire. Journal of Herpetology 34:60-67.

Viskari EL, Karenlampi L. 2000. Roadside Scots pine as an indicator of deicing salt use A comparative study from two consecutive winters. Water, Air and Soil Pollution. 122:405-419.

Welsh HH, Olivier LM. 1998. Stream amphibians as indicators of ecosystem stress: a case study from California’s redwoods. Ecological Applications. 8:1118-1132.

Wilcox DA. 1986. The effects of deicing salts on water chemistry in Pinhook bog, Indiana. Water Resources Bulletin. 22:57-65.

Williams DD, Williams NE, Cao Y. 2000. Road salt contamination of groundwater in a major metropolitan area and development of a biological index to monitor its impact. Water Research. 1:127-138. 
Zedler JB, Paling E, McComb A. 1990. Differential responses to salinity help explain the replacement of native Juncus kraussii by Typha orientalis in Western Australian salt marshes. Australian Journal of Ecology. 15:57-72. 


\title{
Chapter 2: Effects of Six Chemical Deicers on Larval Wood Frogs (Rana sylvatica) ${ }^{1}$
}

\begin{abstract}
Widespread and intensive application of road deicers, primarily road salt $(\mathrm{NaCl})$, in North America threatens water quality and health of freshwater ecosystems. Intensive use of $\mathrm{NaCl}$ can be harmful to sensitive members of freshwater ecosystems such as amphibians. Detection of negative effects of $\mathrm{NaCl}$ application has prompted the search for alternative chemical deicers with lower environmental impacts. We conducted a series of 96 hour acute toxicity tests to determine the negative sensitivity of larval wood frogs (Rana (Lithobates) sylvatica) to six deicing chemicals: urea $\left(\mathrm{CH}_{4} \mathrm{~N}_{2} \mathrm{O}\right)$, sodium chloride $(\mathrm{NaCl})$, magnesium chloride $\left(\mathrm{MgCl}_{2}\right)$, potassium acetate $\left(\mathrm{CH}_{3} \mathrm{COOK}\right)$, calcium chloride $\left(\mathrm{CaCl}_{2}\right)$, and calcium magnesium acetate $\left(\mathrm{C}_{8} \mathrm{H}_{12} \mathrm{CaMgO}_{8}\right)$. Acetates are sometimes touted as 'environmentally friendly' alternatives to $\mathrm{NaCl}$, but have not been examined in enough detail to warrant this designation. When exposed to a range of environmentally realistic concentrations of these chemicals, larvae were least sensitive (i.e., lowest rate of mortality rate) to $\mathrm{CH}_{4} \mathrm{~N}_{2} \mathrm{O}, \mathrm{NaCl}$, and $\mathrm{MgCl}_{2}$ and most sensitive to acetates $\left(\mathrm{C}_{8} \mathrm{H}_{12} \mathrm{CaMgO}_{8}, \mathrm{CH}_{3} \mathrm{COOK}\right)$ and $\mathrm{CaCl}_{2}$. Our observed $\mathrm{LC} 0_{96-\mathrm{h}}$ values for $\mathrm{NaCl}$ were over two times higher than values presented in previous studies, which suggests variability in tolerance among $R$. sylvatica populations. The deicers varied greatly in their toxicity and further research is warranted to examine the differential effects of this suite of deicers to other species.
\end{abstract}

Keywords - transportation, tadpoles, Rana sylvatica, highways, ecotoxicology

\section{Introduction}

\footnotetext{
${ }^{1}$ The material contained in this chapter was previously published in the journal Environmental Toxicology and Chemistry as Harless ML, Huckins CJ, Grant JB, Pypker TG. 2011. Effects of six chemical deicers on larval wood frogs (Rana sylvatica). Environmental Toxicology and Chemistry. 30: 1637-1641.
} 
In cold climates, a myriad of chemicals may be used to remove or prevent the formation of ice on roads, highways, sidewalks, and runways. The most common deicing chemical used on roads is sodium chloride $(\mathrm{NaCl})$ due to its low cost and widespread availability. In the United States, an amount of $\mathrm{NaCl}$ estimated at 10 million metric tons is used each year [1], ranging from 0.3 to 17.6 metric tons per lane mile across 26 states [2]. Roads in the State of Michigan receive more $\mathrm{NaCl}$ per lane mile (12.9 metric tons) than any other Great Lakes state [2]. The intensive and widespread application of $\mathrm{NaCl}$ on an annual basis over the past few decades has resulted in an increase in the salinity of ground and surface waters in North America [3-7]. Anthropogenic sources of $\mathrm{NaCl}$ have been shown to negatively affect ground and surface water quality [8-11]. Direct impacts of $\mathrm{NaCl}$ contamination in surface waters arise primarily from increased chloride concentrations, changes in water density gradients, salt induced stratification, and salt stimulation of algal growth leading to eutrophication [7]. Because of the threat $\mathrm{NaCl}$ poses to human health and the aquatic environment, Environment Canada identified road deicing chemicals as toxic [10].

Due to the known negative environmental impacts of $\mathrm{NaCl}$, numerous alternatives are currently being evaluated to improve deicing operations and reduce the use of deicing chemicals. State and municipal transportation agencies are evaluating these alternatives in an effort to maintain safe winter driving conditions while avoiding the environmental degradation and potential harm to aquatic life caused by $\mathrm{NaCl}$ [1]. These chemicals include different inorganic salts that may be used separately or in conjunction with $\mathrm{NaCl}$ (e.g., $\mathrm{CaCl}_{2}, \mathrm{MgCl}_{2}$, and $\left.\mathrm{KCl}\right)$ [10], sodium formate $\left(\mathrm{CHNaO}_{2}\right)$, calcium magnesium acetate $\left(\mathrm{CMA}, \mathrm{C}_{8} \mathrm{H}_{12} \mathrm{CaMgO}_{8}\right)$, magnesium acetate $\left(\mathrm{C}_{4} \mathrm{H}_{6} \mathrm{MgO}_{4}\right)$, calcium acetate $\left(\mathrm{C}_{4} \mathrm{H}_{6} \mathrm{CaO}_{4}\right)$, glycol liquids, urea $\left(\mathrm{NH}_{4} \mathrm{CO}\right)$ [12], methanol $\left(\mathrm{CH}_{3} \mathrm{OH}\right)$ [13], tetra potassium pyrophosphate [14] and Ice Shear ${ }^{\text {TM }}$ (an equimolar mixture of sodium acetate and sodium formate) [15]. Acetate chemicals, in particular, are often viewed as an environmentally friendly alternative to inorganic salts because they do not contain chloride [7]. Furthermore, not all chemical deicers are equally effective at deicing and may require the application of greater quantities to achieve the same results $[1,16]$. For example, $\mathrm{NH}_{4} \mathrm{CO}$, $\mathrm{CaCl}_{2}$, and CMA require up to 1.2-1.7 times as much deicer to achieve the same deicing 
result as $\mathrm{NaCl}[1]$. This higher application rate could exacerbate negative environmental impacts of these chemicals. Because each of these chemicals differ in their chemical make-up and expected environmental concentrations (i.e., resulting from differences in application, mobility, and decomposition rates), extensive testing of their ecotoxicological effects should predate their widespread use.

Few studies have addressed the effects of $\mathrm{NaCl}$ on wildlife species, but limited research has shown known road salt exposure to negatively affect mammals, birds, invertebrates, and amphibians that utilize roadside habitats [7]. Of these taxa, amphibians are likely to be the most affected by chemical deicer runoff. Amphibians possess highly permeable skin, aquatic larval stages, and many use roadside wetlands for breeding [17]. Embryonic and larval amphibians exposed to salinities beyond their natural range experience substantial negative impacts. For example, high salinity may decrease development rate and increase malformations in embryonic and larval amphibians [1821]. In addition, exposure to $\mathrm{NaCl}$ can increase infection rate of a lethal water mold in embryonic amphibians [22]. Furthermore, amphibians experience elevated levels of $\mathrm{NaCl}$ contamination during spring melt and runoff, and many species breed in small, ephemeral pools where $\mathrm{NaCl}$ runoff is likely to be concentrated [20,21]. As such, amphibians are considered indicators of ecosystem health and are model organisms to investigate the environmental effects of contamination from $\mathrm{NaCl}$ and other chemical deicers. The lethal and sublethal effects of $\mathrm{NaCl}$ contamination on amphibians have been addressed in a few studies that suggest amphibians are negatively impacted at environmentally realistic concentrations $[21,23,24]$. In addition, previous research suggests that frogs and salamanders avoid salt-polluted pools and have not demonstrated local adaptation to high salinities when using roadside water bodies [21,25]. Furthermore, amphibian species may differ in their response to exposure to chemical deicers in runoff, which is predicted to influence demography and community structure [26].

Little is known about the relative population and ecosystem impacts of road salt alternatives and additives within the deicers. One study has directly compared the response of larval amphibians to exposure of $\mathrm{NaCl}$ and alternative deicers. Dougherty 
and Smith [13] compared the lethal effects of $\mathrm{NaCl}$ and an alternative $\left(\mathrm{MgCl}_{2}\right)$ on two native amphibians, green frogs (Rana (Lithobates) clamitans) and American toads (Bufo (Anaxyrus) americanus). To our knowledge, no other studies have directly compared the relative lethal effects of $\mathrm{NaCl}$ and a suite of commonly proposed alternative deicers on North American amphibians. The objective of this study was to assess the direct acute toxicity of six deicing chemicals to native $R$. sylvatica larvae as a predictor of their relative toxicity in the environment.

\section{Materials and Methods}

\section{Experimental design}

We conducted a series of 96 hour acute toxicity tests using $R$. sylvatica larvae to determine the lethal effects of exposure to the following six chemical deicers: urea (pelleted fertilizer, $\mathrm{CH}_{4} \mathrm{~N}_{2} \mathrm{O}$; Garner Brothers Inc., Greenfield, TN), sodium chloride (coarse rock salt, $\mathrm{NaCl}$; Morton Salt Inc., Chicago, IL), calcium chloride (pelleted, $\mathrm{CaCl}_{2}$; Peladow ${ }^{\circledR}$, Dow Chemical Company, Midland, MI), magnesium chloride (anhydrous, $\mathrm{MgCl}_{2}$; Schoenburg Salt Company, Lynbrook, NY), potassium acetate (liquid, KAc, $\mathrm{CH}_{3} \mathrm{COOK}$; Cryotech $\mathrm{CF}^{\circledR}$ Liquid Commercial Deicer, Crytotech Deicing Technology, Fort Madison, IA), and calcium magnesium acetate (pelleted, $\mathrm{CMA}, \mathrm{C}_{8} \mathrm{H}_{12} \mathrm{CaMgO}_{8}$; Cryotech CMA ${ }^{\circledR}$, Crytotech Deicing Technology, Fort Madison, IA).

On May 8, 2008 we collected nine recently deposited $R$. sylvatica egg masses from a palustrine wetland adjacent to a moderately traveled road in Baraga County, Michigan (latitude $46.796 \mathrm{~N}$, longitude $88.390 \mathrm{~W}$ ). This road receives a low amount of salt (4.06 tons per lane mile for the winter of 2007-2008) during winter maintenance activities (DJ Mills, personal communication). We transported the eggs to the lab and randomly assigned each egg masses to one of four aerated $78 \mathrm{~L}$ glass aquaria containing approximately $50 \mathrm{~L}$ of filtered water from Portage Lake, Houghton County, Michigan. The eggs began hatching five days later. The tadpoles were fed ad lib a 3:1 mixture of TetraFin Flake Goldfish Food (Tetra Werke, Melle, Germany) and pulverized Purina Rabbit Chow (Purina Mills, St. Louis, MO) from the time they hatched until they were 
placed into the test chambers. Larvae in test chambers were not fed during the experiment.

Methods for the 96 hour acute toxicity tests strictly followed the protocols set forth by the American Society of Testing Materials (ASTM) [27] and the United States Environmental Protection Agency (USEPA) [28] for static toxicity tests. We chose the range of nominal test concentrations of chemical deicers in this experiment to encompass both known median lethal concentrations ( $\mathrm{LC}^{5} 0_{96-\mathrm{h}}$ ) for $\mathrm{NaCl}$ exposure to larval $R$. sylvatica, and environmental concentrations of $\mathrm{Cl}^{-}$in wetlands and vernal pools resulting from $\mathrm{NaCl}$ pollution $\left(0.002-10.3 \mathrm{~g} \mathrm{~L}^{-1}\right)$ [10,13,20,21,24,25,31]. Test chambers consisted of 44-2.84 L glass jars with loosely fitting glass lids to prevent evaporation and allow for sufficient oxygen exchange. We added two liters of filtered Portage Lake water and the appropriate amount of chemical deicer to obtain the following 11 nominal test concentrations: 0 (negative control), 0.19, 0.32, 0.54, 0.90, 1.50, 2.40, 3.84, 6.14, 9.83, and $15.73 \mathrm{~g} \mathrm{~L}^{-1}$. We replicated the 11 nominal test concentrations four times for a total of 44 experimental units.

Deicer treatments were randomly assigned to each jar. We mixed the treatment solutions until the chemical deicer was completely dissolved in each jar. We pooled tadpoles from all egg masses and randomly assigned tadpoles to each test chamber (experimental units). Each experimental unit contained 10 tadpoles, except for $\mathrm{CaCl}_{2}$ treatments which contained five tadpoles per replicate due to a limited supply of larvae. Test chambers were maintained in the laboratory on a 12:12h light to dark cycle using full spectrum lights. Water temperature averaged $20.7^{\circ} \mathrm{C}$ (range: $19.4-21.8^{\circ} \mathrm{C}$ ) during all trials. Larvae were checked every 24 hours with mortality recorded at each interval. Larvae that were dead or unresponsive to probing with a small net were removed from the jar and preserved in a solution of $10 \%$ formalin. After 96 hours, we preserved all tadpoles remaining in the test chambers. From these data, we estimated the median lethal concentration (LC50) value, or the concentration of the deicer at which mortality of the test population reached $50 \%$. The methods for this calculation are described below. 


\section{Statistical analysis}

Because survival data was not normally distributed, we used non-parametric statistics to examine differences in survival across test concentrations. For each chemical deicer, the proportion of larvae surviving at 96 hours among treatments was analyzed using the non-parametric Kruskal-Wallis one way analysis of variance test. To determine the lowest concentration that had significantly lower survival than in the control we used a Kruskal-Wallis test with multiple post-hoc comparisons. We used the Trimmed Spearman-Karber Program (Version 1.5) to calculate median lethal concentrations (LC50) using untransformed data for each chemical deicer at 24, 48, 72, and 96 hours of exposure [30,31]. We pooled the survival data for each concentration across replicates when calculating the LC50 value. We used "R: A Language and Environment for Statistical Computing" to perform all statistical analyses with an alpha level of 0.05 [32].

\section{Results}

Survival of $R$. sylvatica tadpoles after 96 hours of exposure varied widely across deicers and concentrations (Fig. 2.1). Survival was $100 \%$ in all the control tanks except for the one assigned to the $\mathrm{CH}_{4} \mathrm{~N}_{2} \mathrm{O}$ treatments and in this control survival was $95 \%$. A significant effect of concentration on survival was detected for each deicer $(p \leq 0.038)$. Tadpole survival was significantly lower in concentrations of $\mathrm{CH}_{4} \mathrm{~N}_{2} \mathrm{O}$ at $9.83 \mathrm{~g} \mathrm{~L}^{-1}$ or higher when compared to the control. Exposure to $\mathrm{NaCl}$ and $\mathrm{MgCl}_{2}$ concentrations of $6.14 \mathrm{~g} \mathrm{~L}^{-1}$ or above significantly reduced tadpole survival compared to the control. For $\mathrm{CH}_{3} \mathrm{COOK}$ and $\mathrm{CaCl}_{2}, 3.84 \mathrm{~g} \mathrm{~L}^{-1}$ was the lowest concentration to cause significantly lower survival that the control. Exposure to concentrations of $\mathrm{C}_{8} \mathrm{H}_{12} \mathrm{CaMgO}_{8}$ at or above $1.50 \mathrm{~g} \mathrm{~L}^{-1}$ caused significantly lower survival. Survival in test concentrations below those presented above for each deicer was not significantly lower than that in the control $(p>$ $0.05)$.

Different toxicities of the six chemical deicers suggested by tadpole mortality were supported by estimated $\mathrm{LC} 50_{96-\mathrm{h}}$ values, which ranged from $3.23 \mathrm{~g} \mathrm{~L}^{-1}\left(\mathrm{C}_{8} \mathrm{H}_{12} \mathrm{CaMgO}_{8}\right)$ to 14.63 $\mathrm{g} \mathrm{L}^{-1}\left(\mathrm{CH}_{4} \mathrm{~N}_{2} \mathrm{O}\right.$; Table 2.1). The estimated LC50 $0_{96-\mathrm{h}}$ values were highest for $\mathrm{CH}_{4} \mathrm{~N}_{2} \mathrm{O}, \mathrm{NaCl}$, and $\mathrm{MgCl}_{2}$ and were much lower for acetate chemicals $\left(\mathrm{C}_{8} \mathrm{H}_{12} \mathrm{CaMgO}_{8}\right.$, 
$\mathrm{CH}_{3} \mathrm{COOK}$ ) and $\mathrm{CaCl}_{2}$. For each chemical, the $\mathrm{LC} 50$ values were highest after 24 hours of exposure and decreased by $2-40 \%$ through time until the end of the trial.

\section{Discussion}

Survival of $R$. sylvatica larvae was reduced by exposure to higher concentrations of all chemical deicers examined in this study; however, the response by larvae depended on the chemical deicer. In general, urea and several of the chloride compounds were less toxic than acetates $\left(\mathrm{C}_{8} \mathrm{H}_{12} \mathrm{CaMgO}_{8}, \mathrm{CH}_{3} \mathrm{COOK}\right)$ and $\mathrm{CaCl}_{2}$. At each time step of the test, $\mathrm{C}_{8} \mathrm{H}_{12} \mathrm{CaMgO}_{8}$ exposure induced $50 \%$ mortality at the lowest concentration compared with all other chemicals. In addition, LC50 values decreased with time indicating that either larval R. sylvatica were less able to tolerate or offset the physiological or toxic stress associated with these compounds as duration of exposure increased, or that there was a lag in the lethal effects of initial exposure. If the duration of exposure was critical, this suggests that the effects of exposure to winter season road maintenance involving deicers depends on the type of chemical that is applied, the concentration that builds up in the environment, and/or how long the chemical persists in the environment. If there was a lag response in mortality, then possibly even short-term exposure to the contamination could have lethal effects on amphibian larvae.

We are not aware of previous studies on amphibians that have investigated the toxicity of urea in the context of its use as an alternative chemical deicer. Urea is widely used in the United States as a source of fertilizer for both agricultural and forest lands, as well as an aircraft deicer. Adult amphibians avoid water bodies that receive urea runoff, even when concentrations are lower than the recommended terrestrial fertilization rates [33]. In this study, the high tolerance of $R$. sylvatica tadpoles for urea compared to the other five chemical deicers is expected given that tadpoles excrete urea as a waste product and may retain urea as an osmolyte to protect against salt stress and dehydration [19]. In addition, urea may be used a cryoprotectant by amphibians exposed to low temperatures and freeze/thaw cycles, as is likely during the early breeding cycle of $R$. sylvatica [34]. However, when exposed to high concentrations of urea in their environment, amphibians experience deleterious effects on protein structure and function [35]. Our results suggest 
R. sylvatica larvae appear to tolerate relatively high concentrations $\left(<9.8 \mathrm{~g} \mathrm{~L}^{-1}\right)$ of urea during short-term exposure.

The LC5096-h values estimated in this study are over two times greater than values reported in previous studies with $R$. sylvatica (Table 2.2) [23,24]. The discrepancy between this and other studies suggests that this population may be more tolerant to short-term exposure to $\mathrm{NaCl}$ pollution than are other populations. The larvae tested in this experiment were collected adjacent to a road that receives a small amount of $\mathrm{NaCl}$ with sand as the primary winter maintenance product (4-5\% NaCl; DJ Mills, personal communication). It is possible that localized adaptation or acquired tolerance to $\mathrm{NaCl}$ pollution could solely explain this difference in tolerance although this phenomenon has not been previously documented in R. sylvatica or spotted salamanders (Ambystoma maculatum) $[20,25]$.

In addition, differences in experimental methodology and adherence to ASTM or EPA guidelines may confound comparisons between toxicity studies on chemical deicers with amphibians. The use of food grade salt, alternative methods of statistical analysis [24], purified or de-ionized water [13,21,24], and plastic [21] or glass containers may affect resultant LC5096-h values. Also, feeding tadpoles during exposure and conducted acute toxicity tests at a different room temperature may also influence results [24]. We would expect the use of coarse (non-purified) rock salt used in winter maintenance, a lack of food availability, and the use of glass in experimental chambers in this study (as outlined in ASTM guidelines) would have produced lower $\mathrm{LC}^{5} 0_{96-\mathrm{h}}$ values when compared to previous studies. Plastic containers may have an interactive effect and interfere with estimates of toxicity endpoints if they leach additional chemicals. For example, plasticizers such as bisphenol A (BPA) and dibutyl phthalate (DBP) may cause adverse effects on embryonic or larval amphibians including malformations, early mortality, and sex reversal [36]. Strict standardization of experimental protocol is recommended in future toxicity tests to facilitate comparisons between studies on different populations and/or species. 
$\mathrm{MgCl}_{2}$ and $\mathrm{CaCl}_{2}$ are used primarily as fugitive dust inhibitors on unpaved roadways and to a lesser degree as chemical deicers; however, they are commonly available in stores as consumer level sidewalk deicers. As a chemical deicer, these are slightly more efficient than $\mathrm{NaCl}$ in removing ice. Under the same application rates as $\mathrm{NaCl}, \mathrm{MgCl}_{2}$ and $\mathrm{CaCl}_{2}$ application will contribute more detrimental $\mathrm{Cl}^{-}$into the roadside environment, further expounding the negative impacts of chemical deicer application [1]. This raises serious concerns over the choice of either of these chemicals as an alternative to $\mathrm{NaCl}$. In addition, our results and those of Dougherty and Smith [13] suggest that native larval amphibians are much more sensitive to both $\mathrm{MgCl}_{2}$ and $\mathrm{CaCl}_{2}$ than $\mathrm{NaCl}$.

Variation in salt tolerance among North American amphibians has been described elsewhere (Table 2.2). Embryonic and larval $R$. clamitans tadpoles were found to be relatively insensitive to $\mathrm{NaCl}$ pollution with low mortality rates [21] and moderate LC5096-h values [23]. However, Dougherty and Smith found larval R. clamitans to be intolerant of $\mathrm{NaCl}$ pollution [13]. Larval grey tree frogs (Hyla versicolor) [37] and $A$. maculatum [23] were also reported to be less tolerant of $\mathrm{NaCl}$ pollution than other native species. Larval R. sylvatica and spring peepers (Pseudacris crucifer) appear to be moderately tolerant of $\mathrm{NaCl}$ pollution with low LC5096-h values [23]. Bufo americanus larvae were most tolerant of $\mathrm{NaCl}$ pollution [23] and had 100\% survival in acute exposure up to $3.0 \mathrm{~g} \mathrm{~L}^{-1}$ [13]. This tolerance exhibited by Bufo may stem from past selection to tolerate extreme and rapid drought conditions that could lead to rapid rises in solute concentrations. Different salt tolerance levels among species may influence demography and community structure of native amphibians, particularly for those using roadside breeding habitats $[23,26]$.

To our knowledge, no other studies have investigated the acute effects of the range of $\mathrm{NaCl}$ alternatives on native amphibians as presented here. One study has investigated the acute toxicity of $\mathrm{NaCl}$ and an alternative deicer on amphibians. Results of Dougherty and Smith [13] suggest that B. americanus, $R$. clamitans, and $R$. sylvatica are much more sensitive to $\mathrm{MgCl}_{2}$ exposure than $\mathrm{NaCl}$ pollution with $\mathrm{LC} 0_{96-\mathrm{h}}$ values ranging from 0.11 $0.23 \mathrm{~g} \mathrm{~L}^{-1}$ (Table 2.2). These estimates for $\mathrm{MgCl}_{2}$ exposure are also much lower than 
those estimated in this study suggesting that this population may be more tolerant of exposure than other populations. Knowledge of the $\mathrm{MgCl}_{2}$ tolerance of other groups of native amphibians will help to determine the effect of this pollution source on native amphibian communities. The identification of the environmental effects of alternative chemicals to aquatic and terrestrial organisms is essential prior to implementation of these chemicals as a viable alternative to $\mathrm{NaCl}$.

Knowledge of the potential and quantified environmental impacts of the other alternative deicing chemicals used in this study is limited. This is particularly important to consider for acetate chemicals, as they are generally considered an 'environmentally friendly' alternative to $\mathrm{NaCl}$ [7]. The behaviour of $\mathrm{C}_{8} \mathrm{H}_{12} \mathrm{CaMgO}_{8}$ and $\mathrm{CH}_{3} \mathrm{COOK}$ in the environment raises serious concerns about potential widespread use of these chemicals as a winter maintenance tool. When used as road deicer, average highway spray and runoff concentrations of CMA would likely range from 10 to $100 \mathrm{mgL}^{-1}$ with average annual CMA loadings of 10 tons per mile [38]. In surface water, CMA (acetate) decomposition is predicted to occur in 100 days at $2^{\circ} \mathrm{C}$ and much faster at higher water temperatures [38]. Acetate products may also decrease the $\mathrm{pH}$ of roadside soils and lead to the mobilization of heavy metals. In aquatic environments, acetate products increase oxygen demand and may decrease the biomass of algae $[1,16]$, which is a common food resource for developing larval amphibians. These potential environmental effects of $\mathrm{C}_{8} \mathrm{H}_{12} \mathrm{CaMgO}_{8}$ and $\mathrm{CH}_{3} \mathrm{COOK}$ may have grave implications for sensitive embryonic and larval amphibians as the availability of oxygen and algae is necessary for proper development. Results of this study showing low LC50 $96-\mathrm{h}$ values for $\mathrm{C}_{8} \mathrm{H}_{12} \mathrm{CaMgO}_{8}(3.23$ $\left.\mathrm{g} \mathrm{L}^{-1}\right)$ and $\mathrm{CH}_{3} \mathrm{COOK}\left(4.23 \mathrm{~g} \mathrm{~L}^{-1}\right)$ exposure demonstrates that this alternative deicer may indeed be more harmful than road salt and other deicing chemicals to amphibian communities.

Although the median lethal estimates of chemical deicers to amphibians in this study are above environmentally realistic concentrations of residual chloride from $\mathrm{NaCl}$ application in roadside water bodies, we cannot assume a lack of adverse effects of these chemicals on amphibians. The U.S. EPA categorizes substances with a LC50 above 0.10 
$\mathrm{g} \mathrm{L}^{-1}$ to be practically non-toxic to aquatic organisms (http://www.epa.gov/espp/litstatus/effects/redleg-frog/naled/appendix-i.pdf). Similarly, Environment Canada considers prolonged exposure to $\mathrm{Cl}^{-}$concentrations above $0.220 \mathrm{~g}$ $\mathrm{L}^{-1}$ as harmful to approximately $10 \%$ of aquatic species [10]. However, previous studies indicate $\mathrm{NaCl}$ concentrations as low as $0.078 \mathrm{~g} \mathrm{~L}^{-1}$ can cause significant sublethal effects including decreased survivorship over time, a decreased number of frogs that metamorphose, and delayed time to metamorphosis in R. sylvatica [24]. Residual chloride concentrations in roadside water bodies range from 0.002 to $10.3 \mathrm{~g} \mathrm{~L}^{-1}$, and are highest in early spring and late summer $[21,23,24]$. Considering that inorganic salts other than $\mathrm{NaCl}$ used as chemical deicers will likely contribute more $\mathrm{Cl}^{-}$into the environment, we can expect residual chloride levels to be higher in freshwater systems adjacent to roadways receiving $\mathrm{MgCl}_{2}$ and $\mathrm{CaCl}_{2}$. In addition, the higher application rate required for effective winter maintenance using $\mathrm{C}_{8} \mathrm{H}_{12} \mathrm{CaMgO}_{8}$ and $\mathrm{CH}_{3} \mathrm{COOK}$ suggests that the concentrations of these chemicals in roadside water bodies will be close to or above the LC50 estimates for amphibians.

The effects of chemical deicers in the environment depend on the rate at which they are applied and their persistence in the environment. Road salt alternatives may cause greater environmental degradation because, relative to $\mathrm{NaCl}$, greater quantities need to be applied to achieve similar levels of road deicing $[1,28]$. Thus, the negative impacts of these chemicals to amphibian communities will likely be elevated. Future work should address the suitability of reduced salting practices or non-chemical deicing alternatives instead of alternative chemical deicers on roads adjacent to water bodies.

Acknowledgement-We are indebted to R. Alger, P. Nankervis, M. Mitchell, H. Erickson, and E. Rogers for assistance in both field and laboratory portions of the experiment. We thank three anonymous reviewers for their thorough review of this manuscript and helpful suggestions. Funding for this research was provided by grants from the DeVlieg Foundation, the Chicago Herpetological Society, the Western New York Herpetological Society, the Amphibian Specialist Group of the International Union 
for Conservation of Nature and Natural Resources, the Ecosystem Science Center at Michigan Technological University, and support from the MTU Global Watershed GK12 program to M. Harless. This research has also been supported by funding and infrastructure provided by Michigan Technological University. Embryos were collected under permissions granted by the Keweenaw Bay Indian Community (KBIC) Department of Natural Resources. We conducted laboratory research under permit by Michigan Technological University IUCAC permit L01401.

\section{References}

1. D'Itri FM. 1992. Prologue. In D'Itri FM, ed, Chemical Deicers and the Environment, 1st ed. Lewis Publishing, Boca Raton, FL, USA, pp v-xv.

2. National Research Council. 1991. Highway Deicing: Comparing Salt and Calcium Magnesium Acetate. Special Report 235. National Research Council, Washington, DC, USA.

3. Peters NE, Turk JT. 1981. Increases in sodium and chloride in the Mohawk River, New York, from the 1950's to the 1970's attributed to road-salt. Water Res Bull 17:586597.

4. Wilcox DA. 1986. The effects of deicing salts on vegetation in Pinhook Bog, Indiana. Can J Bot 64:865-74.

5. Williams DD, Williams NE, Cao Y. 2000. Road salt contamination of groundwater in a major metropolitan area and development of a biological index to monitor its impact. Water Res 1:127-138.

6. Benbow ME, Merritt RW. 2004. Road-salt toxicity of select Michigan wetland macroinvertebrates under different testing conditions. Wetlands 24:68-76. 
7. Ramakrishna D, Viraraghavan T. 2005. Environmental impact of chemical deicers- a review. Water Air Soil Poll 166:49-63.

8. Hofmann E, Ford S, Powell E, Klinck J. 2001. Modeling studies of the effect of climate variability on MSX disease in eastern oyster (Crassostrea virginica) populations. Hydrobiologia 460:195-212.

9. Forman R, Alexander L. 1998. Roads and their major ecological effects. Annu Rev Ecol Syst 29:207-31.

10. Environment Canada. 2001. Priority substances list assessment report: Road-salts. Ministry of Public Works and Government Services, Ottawa, Ontario, Canada.

11. Godwin KS, Hafner SD, Buff MF. 2003. Long-term trends in sodium and chloride in the Mohawk River, New York: the effect of fifty years of road-salt application. Environ Pollut 124:273-281.

12. Gales JE, VanderMeulen J. 1992. Deicing Chemical Use in the State of Michigan. In D'Itri FM, ed, Chemical Deicers and the Environment, 1st ed. Lewis Publishing, Boca Raton, FL, USA, pp 135-184.

13. Dougherty CK, Smith GR. 2006. Acute effects of road-deicers on the tadpoles of three anurans. Appl Herpetol 3:87-93.

14. Gutiw PL.1998. Roadside salinity changes by pavement deicer application on a Saskatchewan highway. PhD thesis. University of Regina, Regina, Saskatchewan, Canada.

15. Bang SS, Johnston D. 1998. Environmental effects of sodium acetate/formate deicer, Ice Shear. Arch Environ Contam Toxicol 35:580-57. 
16. Robidoux PY, Delisle CE. 2001. Ecotoxicological evaluation of three deicers ( $\mathrm{NaCl}$, NaFo, CMA) - Effect on terrestrial organisms. Ecotoxicol Environ Safety 48:128-139.

17. Stebbins RC, Cohen NW. 1995. A Natural History of Amphibians, 1st ed. Princeton University Press, Princeton, NJ, USA.

18. Gosner KL, Black IH. 1957. The effects of acidity on the development and hatching of New Jersey frogs. Ecology 38:256-262.

19. Gomez-Mestre I, Tejedo M, Ramayo E, Estepa J. 2004. Developmental alterations and osmoregulatory physiology of a larval anuran under osmotic stress. Physiol Biochem Zool 77:267-274.

20. Karraker NE. 2007a. Investigation of the amphibian decline phenomenon: Novel small-scale factors and a large-scale overview. PhD thesis. State University of New York, Syracuse, NY, USA.

21. Karraker NE. 2007b. Are embryonic and larval green frogs (Rana clamitans) insensitive to road deicing salt? Herpetol Conserv Biol 2:35-41.

22. Karraker NE, Ruthig GR. 2009. Effect of road deicing salt on the susceptibility of amphibian embryos to infection by water molds. Environ Res 109:40-45.

23. Collins SJ, Russell RW. 2009. Toxicity of road salt to Nova Scotia amphibians. Environ Pollut 157:320-324.

24. Sanzo D, Hecnar SJ. 2006. Effects of road de-icing salt $(\mathrm{NaCl})$ on larval Wood frogs (Rana sylvatica). Environ Poll 140:247-56. 
25. Turtle SL. 2000. Embryonic survivorship of the Spotted Salamander (Ambystoma maculatum) in roadside and woodland vernal ponds in southeastern New Hampshire. $J$ Herpetol 34:60-67.

26. Karraker NE, Gibbs JP, Vonesh JR. 2008. Impacts of road de-icing salt on the demography of vernal pool-breeding amphibians. Ecol Appl 18:724-734.

27. American Society for Testing and Materials 2006. Standard guide for conducting acute toxicity tests on test materials with fishes, macroinvertebrates, and amphibians. ASTM E729-96. In: ASTM. Annual Book of ASTM Standards, Volume 11.06. Philadelphia (PA), USA: p 79-100.

28. United States Environmental Protection Agency. 1993. Methods for measuring the acute toxicity of effluents and receiving waters to freshwater and marine organisms. EPA 600/4-90/027F. Technical Report. Cincinnati, OH, USA.

29. Kaushal SS, Groffman PM, Likens GE, Belt KT, Stack WP, Kelly VR, Band LE, Fisher GT. 2005. Increased salinization of fresh water in the northeastern United States. Proc Natl Acad Sci USA 102:13517-13520.

30. Meister R, Van Den Brink PJ. 2000. The Analysis of Laboratory Toxicity Experiments. In Sparks T, ed, Statistics in Ecotoxicology, 1st ed. Wiley Publishing, Chichester, England, pp 100-118.

31. Hamilton MA, Russo RC, Thurston RV. 1977. Trimmed Spearman-Karber method for measuring median lethal concentrations in toxicity bioassays. Environ Sci Technol 11:714-719.

32. R Development Core Team. 2010. R: A Language and Environment for Statistical Computing, version 2.11.1. R. Foundation for Statistical Computing, Vienna, Austria. 
33. Marco A, Cash D, Belden LK, Blaustein AR. 2001. Sensitivity to urea fertilization in three amphibian species. Arch Environ Contam Toxicol 40:406-409.

34. Costanzo JP, Lee RE, Ultsch GR. 2008. Physiological ecology of overwintering in hatchling turtles. $J$ Exp Zool 309A: 297-379.

35. Creighton TE. 1991. Molecular chaperones: unfolding protein folding. Nature 352:17-18.

36. Oehlmann J, Schulte-Oehlmann U, Kloas W, Jagnytsch O, Lutz I, Kusk KO, Wollenberger L, Santos EM, Paul GC, Van Look KJW, Tyler CR. 2009. A critical analysis of the biological impacts of plasticizers on wildlife. Phil. Trans. R. Soc. B 364:2047-2062.

37. Brand AB, Snodgrass JW, Gallagher MT, Casey RE, Van Meter R. 2009. Lethal and sublethal effects of embryonic and larval exposure of Hyla versicolor to Stormwater pond sediments. Environ Contam Toxicol 58:325-331.

38. Horner, RR. 1988. Environmental monitoring and evaluation of calcium magnesium acetate (CMA). NCHRP-305. TRB, National Research Council, Washington DC, USA. 
Table 2.1

Median lethal concentration values (LC50, $\mathrm{g} \mathrm{L}^{-1}$ ) with their $95 \%$ confidence limits for larval Rana sylvatica at $24,48,72$ and 96 hours of exposure to six chemical deicers during acute toxicity tests $(n=4)$.

\begin{tabular}{ccccccc}
\hline Value & $\mathrm{CH}_{4} \mathrm{~N}_{2} \mathrm{O}$ & $\mathrm{NaCl}$ & $\mathrm{MgCl}_{2}$ & $\mathrm{CH}_{3} \mathrm{COOK}$ & $\mathrm{CaCl}_{2}$ & $\mathrm{C}_{8} \mathrm{H}_{12} \mathrm{CaMgO}_{8}$ \\
\hline $\mathrm{LC50}_{24-h}$ & 14.63 & 9.12 & 7.37 & 7.03 & 4.85 & 3.43 \\
& $(12.83-16.69)$ & $(8.53-9.82)$ & $(6.81-7.99)$ & $(6.22-7.95)$ & $(4.16-5.65)$ & $(3.13-3.81)$ \\
$\mathrm{LC50}_{48-h}$ & 14.37 & 7.82 & 7.28 & 5.42 & 4.72 & 3.39 \\
& $(12.77-16.18)$ & $(7.64-8.01)$ & $(6.73-7.92)$ & $(4.85-6.06)$ & $(4.08-5.47)$ & $(3.07-3.74)$ \\
$\mathrm{LC50}_{72-h}$ & 14.37 & 7.64 & 7.24 & 4.76 & 4.18 & 3.31 \\
& $(12.77-16.18)$ & $(7.46-7.82)$ & $(6.64-7.82)$ & $(4.27-5.31)$ & $(3.69-4.73)$ & $(2.97-3.68)$ \\
$\mathrm{LC50}_{96-h}$ & $(12.55-16.26)$ & $(7.31-7.82)$ & $(6.54-7.74)$ & $(3.84-4.66)$ & $(3.46-4.57)$ & $(2.94-3.59)$ \\
\hline
\end{tabular}


Table 2.2

Median lethal concentration values (LC5096-h, $\mathrm{g} \mathrm{L}^{-1}$ ) and 95\% C.I. where available for larval amphibians native to the Northern and Eastern United States during acute exposure to deicing chemicals.

\begin{tabular}{|c|c|c|}
\hline Species & Deicer & $\mathrm{LC}_{50}$ \\
\hline Ambystoma maculatum & $\mathrm{NaCl}$ & $1.84(1.42-2.39)^{\mathrm{d}}$ \\
\hline \multirow[t]{2}{*}{ Bufo americanus } & $\mathrm{NaCl}$ & $6.14(5.94-6.48)^{\mathrm{d}}$ \\
\hline & $\mathrm{MgCl}_{2}$ & $0.105^{\mathrm{a}}$ \\
\hline Hyla versicolor & $\mathrm{NaCl}$ & $1.05^{\mathrm{c}}$ \\
\hline Pseudacris crucifer & $\mathrm{NaCl}$ & $4.43(3.89-5.05)^{\mathrm{d}}$ \\
\hline \multirow[t]{3}{*}{ Rana clamitans } & $\mathrm{NaCl}$ & $0.406^{\mathrm{a}}$ \\
\hline & & $4.86(4.42-5.36)^{\mathrm{d}}$ \\
\hline & $\mathrm{MgCl}_{2}$ & $0.116^{\mathrm{a}}$ \\
\hline \multirow[t]{7}{*}{ Rana sylvatica } & $\mathrm{NaCl}$ & $2.64(2.53-2.74)^{\mathrm{b}, *}$ \\
\hline & & $2.69(2.31-3.14)^{\mathrm{d}}$ \\
\hline & & $5.11(5.46-6.93)^{\mathrm{b}, * *}$ \\
\hline & $\mathrm{MgCl}_{2}$ & $0.23^{\mathrm{a}}$ \\
\hline & $\mathrm{Ca}\left(\mathrm{CH}_{3} \mathrm{CO}_{2}\right)_{2}$ & $0.48^{\mathrm{a}}$ \\
\hline & $\operatorname{Mg}\left(\mathrm{CH}_{3} \mathrm{CO}_{2}\right)_{2}$ & $6.61^{\mathrm{a}}$ \\
\hline & $\mathrm{Na}_{4} \mathrm{Fe}(\mathrm{CN})_{6}$ & $2.06^{\mathrm{a}}$ \\
\hline $\begin{array}{l}\mathrm{a}=\text { Dougherty and Smitl } \\
\mathrm{b}=\text { Sanzo and Hecnar }(2 \\
\mathrm{c}=\text { Brand et al. }(2009) \\
\mathrm{d}=\text { Collins and Russell } \\
{ }^{*}=\text { Calculated using Spe } \\
{ }^{* *}=\text { Calculated using Pr }\end{array}$ & $\begin{array}{l}(2006) \\
006) \\
2009) \\
\text { arman-Karber Ar } \\
\text { bit Analysis }\end{array}$ & alysis \\
\hline
\end{tabular}




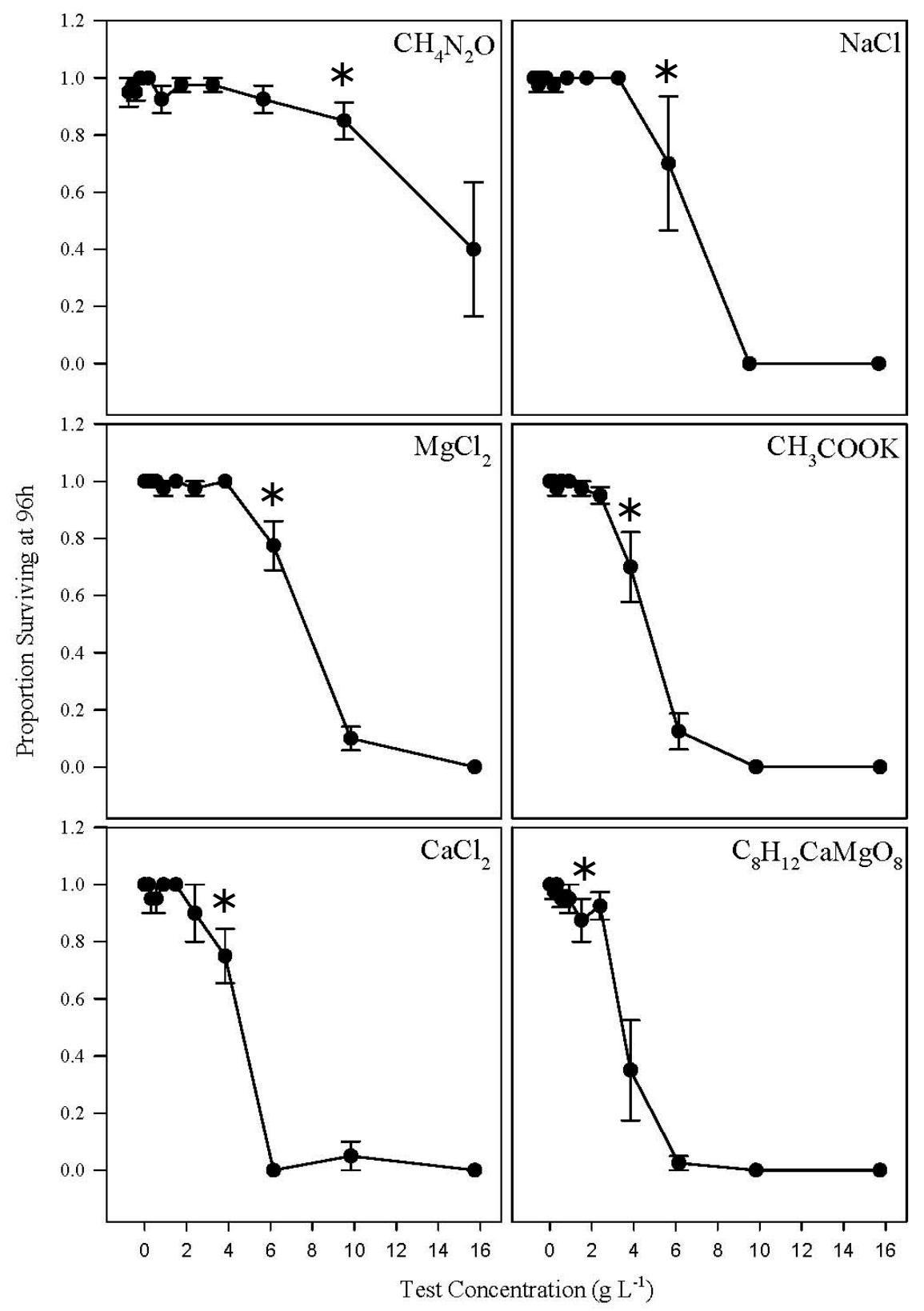

Figure 2.1: Mean proportion of surviving Rana sylvatica tadpoles after 96 hours of exposure to 10 nominal test concentrations of six chemical deicers. Error bars represent \pm 1 S.E. Asterisks indicate the lowest test concentration at which survival was significantly lower than in the control ( $\mathrm{n}=4$ replicates per concentration). 


\title{
Chapter 3: Sublethal Effects of Road Salt (NaCl) Exposure to Larvae of Two Amphibian Species
}

\begin{abstract}
Road salt $(\mathrm{NaCl})$ is heavily applied in cold climates of North America causing a degradation of quality of surface and groundwater bodies. Amphibians can be considered indicator organisms in freshwater systems and are ideal to address the impacts of road salt use on roadside wetlands and vernal pools. While estimates of the median lethal $\mathrm{NaCl}$ concentration $\left(\mathrm{LC}_{50}\right)$ are useful for effective management, understanding the sublethal or chronic effects of exposure to lower levels of $\mathrm{NaCl}$ on these species will provide a better understanding of the potential developmental effects larval amphibians may experience. This is particularly important as species of amphibians using these roadside water bodies employ different life histories strategies. These differences may play a part in the demography of amphibian species in cold climates. I examined relative metrics of fitness in response to chronic $\mathrm{NaCl}$ exposure in two amphibian species that employ different life history strategies, wood frogs (Lithobates sylvatica) and green frogs (L. clamitans). The larvae of these two amphibians responded very differently to exposure to sublethal concentrations of $\mathrm{NaCl}$ with significant differences in L. sylvatica in terms of survival, size, the proportion of larvae or time to complete metamorphosis, or frequency of physical deformities in 100 days of exposure. However, presence of edema was significantly higher in the highest test concentration $\left(750 \mathrm{mg} \mathrm{L}^{-1}\right)$ suggesting that $\mathrm{NaCl}$ exposure is a significant physiologic stressor to these rapidly developing larvae. For L. clamitans, $\mathrm{NaCl}$ exposure significantly decreased total size of larvae, whereas all other metrics were not significantly affected within 300 days of exposure. Evidence of these potentially harmful responses in these larvae suggests that prolonged exposure to $\mathrm{NaCl}$ may compromise fitness in amphibian communities.
\end{abstract}

Keywords: Road salt, sodium chloride, sublethal, chronic toxicity, edema, Rana sylvatica, Rana clamitans

\section{Introduction}


Sodium chloride $(\mathrm{NaCl})$ is widely used in cold climates to remove or prevent the formation of ice on roads, highways, sidewalks, and airport runways. Each year an estimated 10 million metric tons is spread on these surfaces in the United States (D'Itri 1992). Across the country the application of $\mathrm{NaCl}$ varies from 0.3 to 17.6 metric tons per lane mile in 26 states (National Research Council 1991). Sodium chloride applied to a roadway has the potential to reach nearby surface water bodies such as wetlands and vernal pools (Environment Canada 2001; Forman et al. 2003). Not surprisingly, this intensive and widespread application of $\mathrm{NaCl}$ on an annual basis over the past few decades has resulted in an increase in the salinity of ground and surface waters in North America (Benbow and Merritt 2004; Ramakrishna and Viraraghavan 2005; Findlay and Kelly 2011) resulting in degradation of ground and surface water quality (Forman and Alexander 1998; Environment Canada 2001; Hoffman et al. 2000; Godwin et al. 2003).

Freshwater organisms vary widely in their tolerance of salinity (e.g., from $\mathrm{NaCl}$ ) in their immediate environment (Environment Canada 2001). These differences in tolerance may cause a reduction in the diversity and overall abundance of aquatic organisms in roadside environments (Kaushal et al. 2005; Karraker et al. 2008). These differences are likely most notable in communities of less tolerant organisms such as amphibians. Amphibians are sensitive to environmental pollutants because they possess highly permeable skin, aquatic larval stages, and many use roadside wetlands for breeding (Stebbins and Cohen 1995).

Brief exposure to high salinities may decrease survival, decrease development rate, increase malformations (Gosner and Black 1957; Gomez-Mestre et al. 2004; Karraker $2007 \mathrm{a}, b)$ and increase the rate of infection of embryonic amphibians by lethal water mold (Karraker and Ruthig 2009). In addition, amphibian species respond differently to road salt exposure, and this tolerance may impact the demography of local species (Sanzo and Hecnar 2006; Karraker et al. 2008). Spring snowmelt could transport $\mathrm{NaCl}$ into roadside water bodies (Findlay and Kelly 2011) leading to spring and/or fall peaks in chloride concentrations. However, in some systems high evaporative demand in summer could 
cause the chloride levels in these surface water bodies to increase dramatically as salts are concentrated by evaporation of water (Collins and Russell 2009; Kaushal et al. 2005).

Exposure to high salinity during development may cause significant harm to larval amphibians. Thus, it is important to examine the long term or sublethal effects of this exposure on the survival of amphibian larvae. Examining species with different life history strategies will allow for a greater understanding of the potential developmental effects of this stressor. Both wood frogs (Lithobates sylvatica) and green frogs ( $L$. clamitans) breed in palustrine wetlands in the northern United States; however they tend to display different life history strategies and habitat use. L. sylvatica breed primarily in vernal pools and shallow wetlands, whereas L. clamitans tend to breed in larger wetlands with longer hydroperiods (Conant and Collins 1998). Further, L. sylvatica are one of the first amphibians to breed in the spring while L. clamitans breed in early summer. $L$. sylvatica larvae metamorphose quickly (five to nine weeks; Karraker 2007a) with $L$. clamitans larvae remaining as tadpoles for at least one year (Pauley and Lannoo 2005).

Few studies have addressed the impacts of road salt exposure on North American amphibian larvae. Most studies focus on identifying the concentration of $\mathrm{NaCl}$ during short-term exposure that leads to survival declines for a specific species (e.g., median lethal concentration or LC $_{50}$ estimate) (Karraker 2007a; Sanzo and Hecnar 2006; Collins and Russell 2009; Dougherty and Smith 2006; Harless et al. 2011). These resultant estimates are important for effective environmental management, yet many of these estimates exceed the mean environmentally realistic $\mathrm{NaCl}$ concentrations measured in roadside water bodies (Collins and Russell 2009; Sanzo and Hecnar 2006). Little is known about the effects of $\mathrm{NaCl}$ exposure on other metrics of amphibian fitness such as time to metamorphosis, duration of metamorphosis, size at metamorphosis, and presence of either physical deformities or behavioral abnormalities. These sublethal effects may have substantial negative impacts on amphibian populations inhabiting roadside water bodies. The goal of this study is to examine the sublethal effects of chronic exposure to 
environmentally relevant concentrations of $\mathrm{NaCl}$ by two amphibian species, $L$. sylvatica and L. clamitans, common to cold climates of North America.

\section{Methods}

\section{Study Organisms}

I collected nine recently deposited L. sylvatica egg masses on May 8, 2008 from a palustrine wetland adjacent to a moderately traveled road in Baraga County, Michigan (latitude $46.796 \mathrm{~N}$, longitude $88.390 \mathrm{~W}$ ). From this same wetland, I collected six recently deposited L. clamitans egg masses on July 8, 2008. This road receives a low amount of salt (4.06 tons per lane mile for the winter of 2007-2008) during winter maintenance activities (DJ Mills, Baraga County Road Commission, personal communication). I transported the eggs to the lab and randomly assigned each egg mass to one of four aerated $78 \mathrm{~L}$ glass aquaria containing approximately $50 \mathrm{~L}$ of filtered water from Portage Lake, Houghton County, Michigan. The L. sylvatica eggs began hatching five days after collection with the L. clamitans eggs hatching two days after collection.

\section{Chronic Toxicity Tests}

Larvae were transferred to experimental test chambers when they reabsorbed their gills and reached Gosner stage 25 (Gosner 1960). I pooled larvae from different egg mass and randomly assigned 30 larvae of similar size to each test chamber. Test chambers consisted of $38 \mathrm{~L}$ glass aquaria filled with $20 \mathrm{~L}$ of filtered Portage Lake water and the appropriate amount of $\mathrm{NaCl}$ to obtain the following five nominal test concentrations: 0 (negative control), 48, 120, 300, and $750 \mathrm{mg} \mathrm{L}^{-1}$. I chose the range of nominal test concentrations of $\mathrm{NaCl}$ in this experiment to include the lower environmental concentration of $\mathrm{Cl}^{-}$in wetlands and vernal pools $\left(2.1-10300 \mathrm{mg} \mathrm{L}^{-1}\right.$; Turtle 2000; Environment Canada 2001; Dougherty and Smith 2006; Sanzo and Hecnar 2006). I replicated the five nominal test concentrations four times for a total of 20 experimental units. Each test chamber was outfitted with a glass lid and one aerator to provide oxygen to the developing tadpoles. 
Larvae were fed a 3:1 mixture of TetraFin Flake Goldfish Food (Tetra Werke, Melle, Germany) and pulverized Purina Rabbit Chow (Purina Mills, St. Louis, MO) every two days throughout the experiment. Test chambers were maintained in the laboratory on a 12:12h light to dark cycle using full spectrum lights. Air temperature remained stable (range: $18.7-22.1^{\circ} \mathrm{C}$ ) during each experiment. I performed water changes every 7-10 days or as needed. Water changes consisted of siphoning $18 \mathrm{~L}$ of solution and excess food from each tank. Larvae were removed from the test chamber during cleaning and replaced into a cleaned tank with $18 \mathrm{~L}$ of fresh water with the appropriate amount of $\mathrm{NaCl}$. The larvae in each test chamber were fed following each water change.

Larvae were checked every 24 hours and mortality was recorded at each interval. Significant developmental events such as the appearance of hind or forelimbs were recorded for each test chamber. Presence of any physical or behavioral deformities and/or abdominal edema was recorded in these daily observations. Larvae that were dead or unresponsive to probing with a small net or those that completed metamorphosis were removed and preserved in a solution of $10 \%$ formalin. The $L$. sylvatica experiment was terminated after 100 days when all tadpoles began metamorphosis (emergence of at least one front limb). I terminated the L. clamitans experiment after 300 days and preserved all tadpoles remaining in the test chambers. I dry blotted each specimen to obtain its wet mass. Because of a high incidence of edema in L. sylvatica, I did not use wet mass data as a metric of fitness in either experiment. All tadpoles and metamorphs were photographed to obtain total length (TL, from snout to tip of tail) and snout-vent length (SVL) measurements using Sigma Scan Pro (Systat Software Inc., San Jose, CA). For $L$. sylvatica, I limited length analyses to those larvae that were removed from the experiment following the completion of metamorphosis. For L. clamitans, all larvae surviving to the end of the test were included in the analysis of TL and SVL measurements. Individuals with tail damage (e.g., bitten by conspecifics) or significant deformities resulting in alteration of the tail were removed from this portion of the analysis. 


\section{Environmental Concentrations}

To determine the environmentally realistic concentrations of $\mathrm{Cl}^{-}$resulting from road salt application in the local area, I collected water samples from 16 wetlands averaging 2957 m (2 - 19082) from a salt-treated highway (US 41) in Baraga, Houghton, and Keweenaw Counties in the Upper Peninsula of Michigan once every two weeks throughout the amphibian breeding season (May through September). This area receives on average 141 inches of snow annually (NOAA 2011). Road salt application on this highway is through the use of a mixture of sand and rock salt $(\mathrm{NaCl})$. Application rates for the winters of 2009-2010 range from 26.16 to 32.44 tons per lane mile in Baraga abd Houghton counties (J. Lake MDOT pers. comm.). These values are much higher than the average application rate in Michigan (12.9 tons per lane mile) as well as average rates across the Great Lakes States (9.36 tons per lane mile; National Research Council 1991). Water samples were returned to the laboratory and stored at 4 [C. I filtered the samples through a $0.45 \mu \mathrm{m}$ cellulose acetate filter and quantified chloride concentration using ion chromatography (Dionex ICS-900, AS22 4 mm column, Fisher Scientific Inc., Sunnyvale CA).

\section{Statistical analysis}

In the L. sylvatica experiment I removed two tanks (one each of the $300 \mathrm{mg} \mathrm{L}^{-1}$ and 750 $\mathrm{mg} \mathrm{L}^{-1} \mathrm{NaCl}$ treatments) due to significant mortality as a result of an overgrowth of bacteria. I used a Shapiro-Wilk test for normality for the distribution of residuals. I used a one-way analysis of variance (ANOVA) to determine if proportion of surviving larvae, TL, SVL, proportion of deformed larvae, proportion of larvae with edema, proportion of larvae reaching metamorphosis or the number of days to complete metamorphosis were significantly affected by $\mathrm{NaCl}$ concentration. I then used Tukey multiple comparisons to identify significant differences between test concentrations for these variables.

Chloride concentration failed the Shapiro-Wilk test for normality test even after multiple transformation attempts in both years. I used the nonparametric Kruskal-Wallis one way analysis of variance test to examine differences in chloride concentration across sample 
months with multiple post hoc comparisons to test for differences between months. At the end of each experiment, I calculated the proportion of larvae in each test chamber that survived through metamorphosis. I define the start of metamorphosis as the emergence of at least one forelimb (Gosner stage 42), the end of metamorphosis as the complete reabsorption of the tail (tail length $<2 \mathrm{~mm}$; Gosner stage 46, Gosner 1960), and the time to complete metamorphosis as the number of days between these developmental achievements. I considered each tank as an experimental unit in both tests. I used "R: A Language and Environment for Statistical Computing” to perform all statistical analyses with an alpha level of 0.05 (R Development Core Team 2010).

\section{Results}

\section{Chronic Toxicity Tests}

For L. sylvatica, the majority of the tadpoles survived to the end of the test (mean $=27.7$ ). Survival remained above $80 \%$ across test concentrations (Figure 3.1). I observed the largest larvae in the highest $\mathrm{NaCl}$ exposure $\left(750 \mathrm{mgL}^{-1}\right)$, but size was not significantly different across test concentrations (TL: $\mathrm{F}_{4,13}=1.522, \mathrm{P}=0.235 ; \mathrm{SVL}: \mathrm{F}_{4,13}=0.372, \mathrm{P}=$ 0.824; Table 3.1). The majority of surviving L. sylvatica larvae completed metamorphosis during the experiment (Figure 3.2). Neither the proportion of larvae surviving to the end of test $\left(\mathrm{F}_{4,13}=1.052, \mathrm{P}=0.419\right)$, nor proportion of larvae completing metamorphosis, varied significantly by test concentration $\left(\mathrm{F}_{4,13}=1.446, \mathrm{P}=0.274\right)$. The number of days to complete metamorphosis was highest in the $300 \mathrm{mgL}^{-1}$ treatment but was not significantly across test concentrations $\left(\mathrm{F}_{4,13}=0.763, \mathrm{P}=0.567\right.$, Figure 3.3).

I observed 27 juvenile L. sylvatica (5\% of all tadpoles) with physical deformities during the experiment and $40 \%$ of these died before the end of the test. The majority of tadpoles had a singular deformity including rear legs that were elongated, stretched out, and thin (70\%). Other deformities included bent tails (11\%), missing a portion of the bottom jaw (7\%), scoliosis (4\%), and one missing forelimb (4\%) with one tadpole exhibiting both deformed rear legs and missing a portion of the jaw (4\%). The proportion of deformed 
larvae varied across test concentration but was not significantly different among or between the five treatments $\left(\mathrm{F}_{4,13}=0.3269, \mathrm{P}=0.855\right.$; Figure 3.4).

Swelling as a result of abdominal edema occurred in $119 \mathrm{~L}$. sylvatica larvae with $72 \%$ of these larvae surviving to the end of the test. The proportion of juvenile L. sylvatica exhibiting abdominal edema was significantly different across test concentrations $\left(\mathrm{F}_{4,13}=\right.$ $7.882, \mathrm{P}=0.002$ ). In addition, larvae in the $750 \mathrm{mgL}^{-1}$ treatment had a significantly higher proportion of edema than those in the control $(\mathrm{P}=0.001), 48 \mathrm{mgL}^{-1}(\mathrm{P}=0.008)$, or $120 \mathrm{mgL}^{-1}$ treatments $(\mathrm{P}=0.017$, Figure 3.5).

For L. clamitans, survival was highest in the $48 \mathrm{mgL}^{-1}$ treatment and lowest in the control $\left(\mathrm{F}_{4,15}=1.308, \mathrm{P}=0.312\right.$; Figure 3.1$)$. There were no significant differences in survival between test concentrations $(\mathrm{P}>0.05)$. At the end of the exposure period, tadpoles were significantly different in $\mathrm{TL}\left(\mathrm{F}_{4,15}=4.047, \mathrm{P}=0.020\right)$, with the largest tadpoles in the control (Table 3.1). Total tadpole length decreased in higher $\mathrm{NaCl}$ concentrations with significantly larger tadpoles in the control versus the $48 \mathrm{mgL}^{-1}(\mathrm{P}=0.066), 300 \mathrm{mgL}^{-1}(\mathrm{P}$ $=0.040)$, and $750 \mathrm{mgL}^{-1}$ treatments $(\mathrm{P}=0.019)$. Measurements of SVL did not significantly vary between test concentrations $\left(\mathrm{F}_{4,15}=0.373, \mathrm{P}=0.824\right)$. All other comparisons were not significant $(\mathrm{P}>0.05)$. No L. clamitans larvae exhibited signs of edema. Nine tadpoles started, but only two completed metamorphosis (one each in the control and $120 \mathrm{mLL}^{-1}$ concentrations) within 300 days. Thus, I did not examine the number of days to complete metamorphosis in the L. clamitans test.

The proportion of $L$. clamitans larvae exhibiting a physical deformity was highest in the control and decreased as test concentration increased (Figure 3.4). I observed 36 larval and juvenile $L$. clamitans with at least one physical deformity ( $6 \%$ of all tadpoles). The majority of these deformities included bent tails (94\%) or a double lobed tail (3\%) with one larva exhibiting both deformities. Differences in the proportion of deformities were not significant among $\left(\mathrm{F}_{4,15}=0.250, \mathrm{P}=0.905\right)$ or between the test concentrations $(\mathrm{P}>$ $0.05)$. 


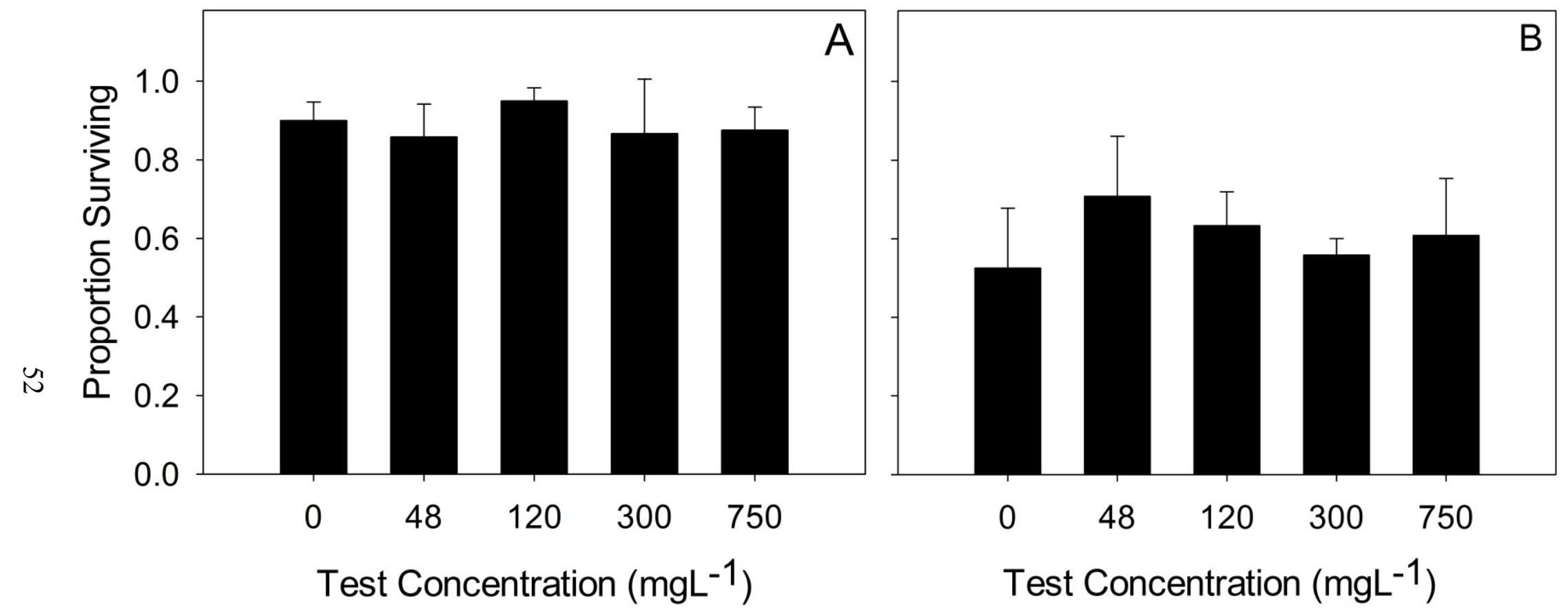

Figure 3.1: Mean proportion of Lithobates sylvatica (A) and L. clamitans (B) larvae surviving to the end of the test in each test concentration. Error bars represent \pm 2 S.E. 
Table 3.1

Mean (range) total length (TL) and snout-vent length (SVL) of L. sylvatica that completed metamorphosis and L. clamitans that survived to the end of the test exposure.

\begin{tabular}{cccccc}
\hline \multirow{2}{*}{$\begin{array}{c}\text { Test } \\
\begin{array}{c}\text { Concentration } \\
\left(\mathrm{mgL}^{-1}\right)\end{array}\end{array}$} & TL $(\mathrm{mm})$ & & \multicolumn{2}{c}{ Lithobates clamitans } \\
\cline { 2 - 3 } & $19.06(17.8-20.9)$ & $16.29(15.3-17.3)$ & & $57.90(51.2-65.3)$ & $21.70(19.9-24.1)$ \\
\hline 0 & $19.23(17.6-21.4)$ & $16.13(15.3-16.9)$ & & $51.15(49.9-52.5)$ & $19.40(18.7-20.2)$ \\
\hline 48 & $19.63(19.2-20.6)$ & $16.14(15.3-16.9)$ & $52.44(48.3-55.6)$ & $19.06(17.5-19.9)$ \\
\hline 120 & $19.18(18.6-19.9)$ & $16.14(15.9-16.3)$ & $50.18(47.9-51.4)$ & $18.86(17.7-19.4)$ \\
\hline 300 & $19.97(19.3-20.9)$ & $17.11(16.9-17.4)$ & & $49.66(47.6-51.9)$ & $18.32(17.4-19.3)$ \\
\hline 750 & 458 & 488 & 297 & 311 \\
\hline $\mathrm{N}$ & & & & & \\
\hline
\end{tabular}




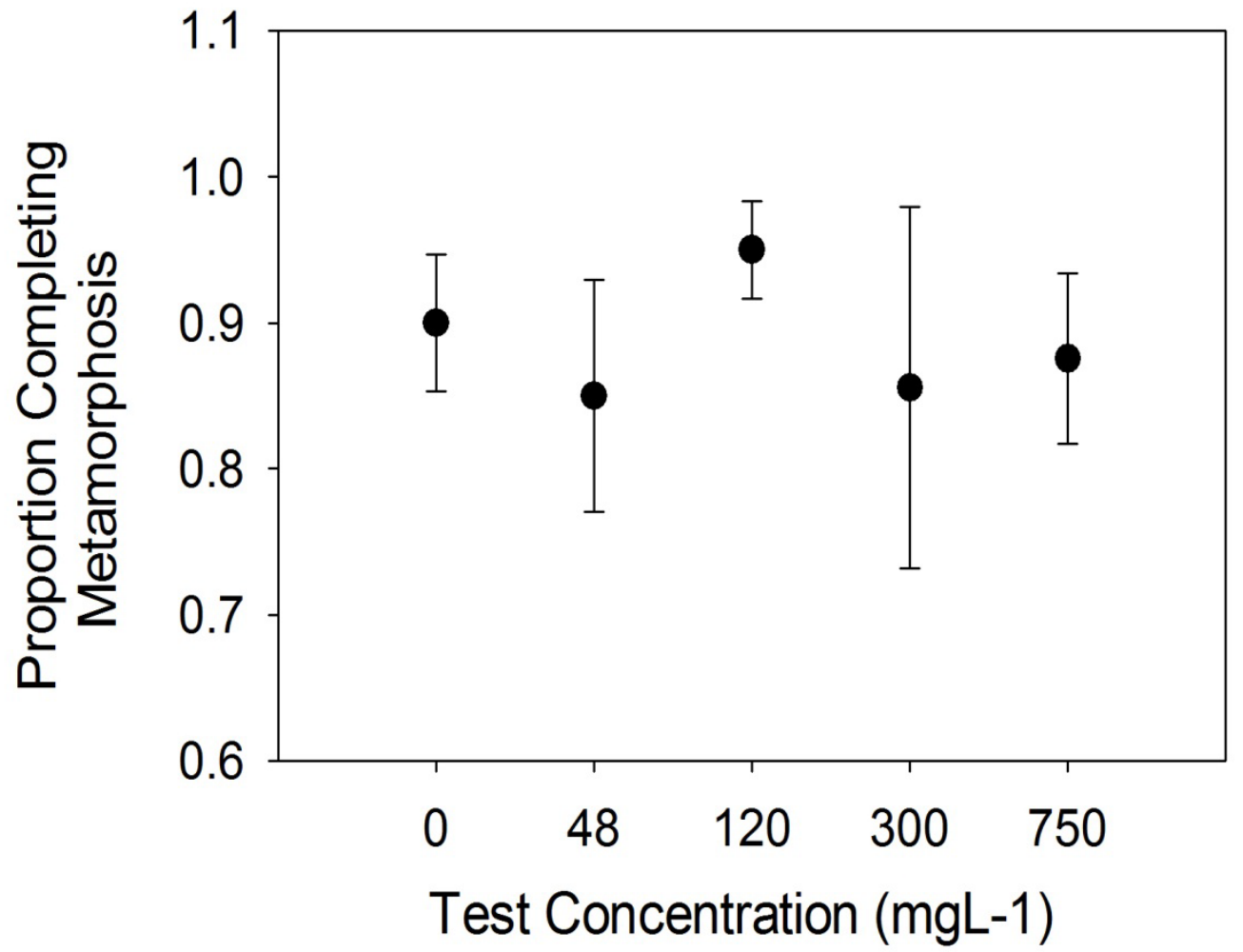

Figure 3.2: Mean proportion of L. sylvatica larvae completing metamorphosis in each test concentration. Error bars represent \pm 2 S.E. 


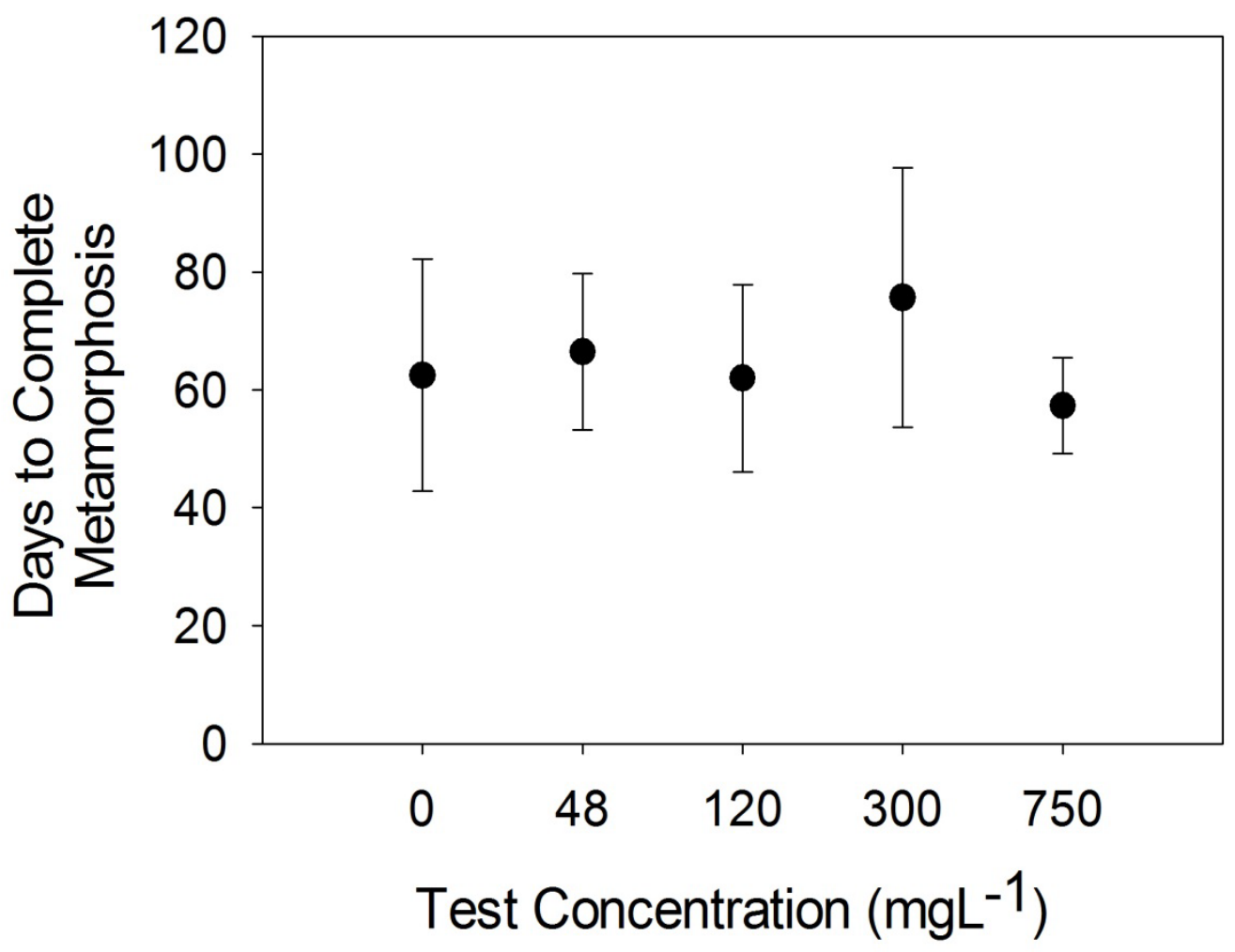

Figure 3.3: Number of days for $L$ sylvatica larvae to complete metamorphosis in each test concentration. Error bars represent \pm 2 S.E. 

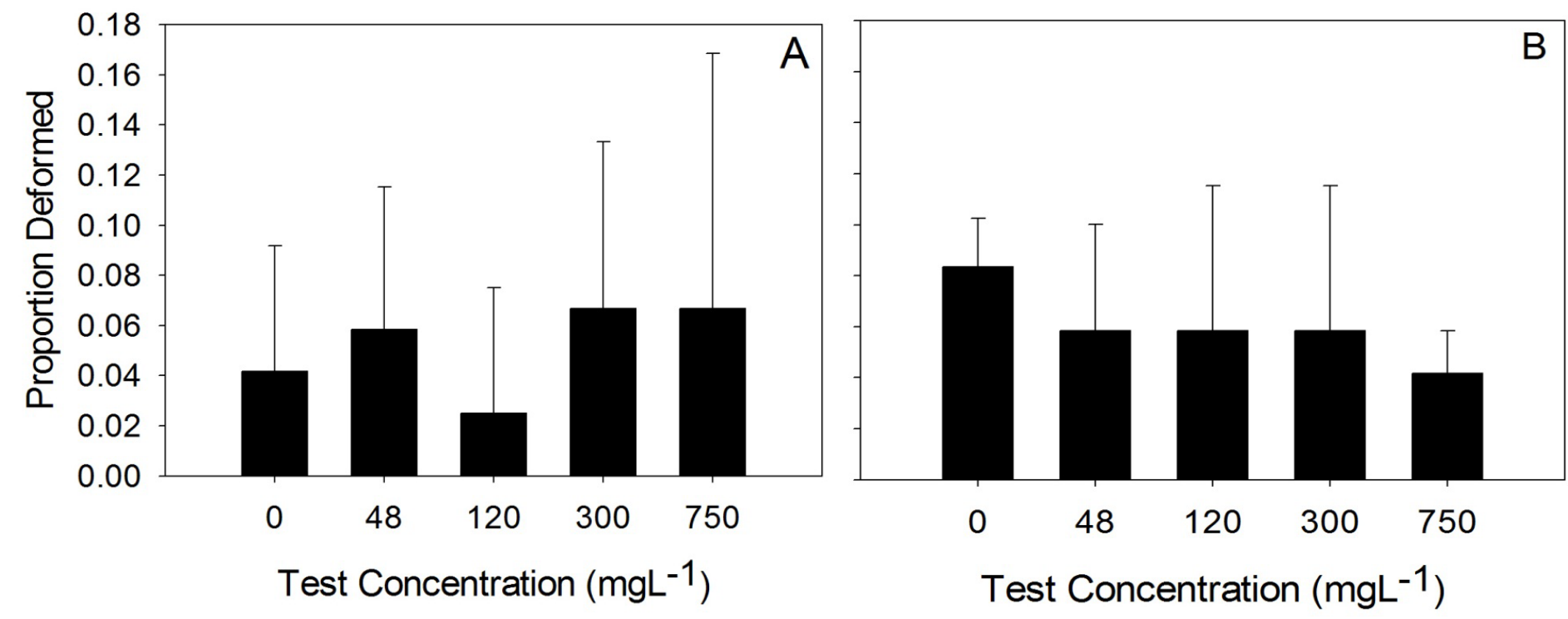

Figure 3.4: Mean proportion of Lithobates sylvatica (A) and L. clamitans (B) larvae exhibiting a physical deformity in each test concentration. Error bars represent \pm 2 S.E. 


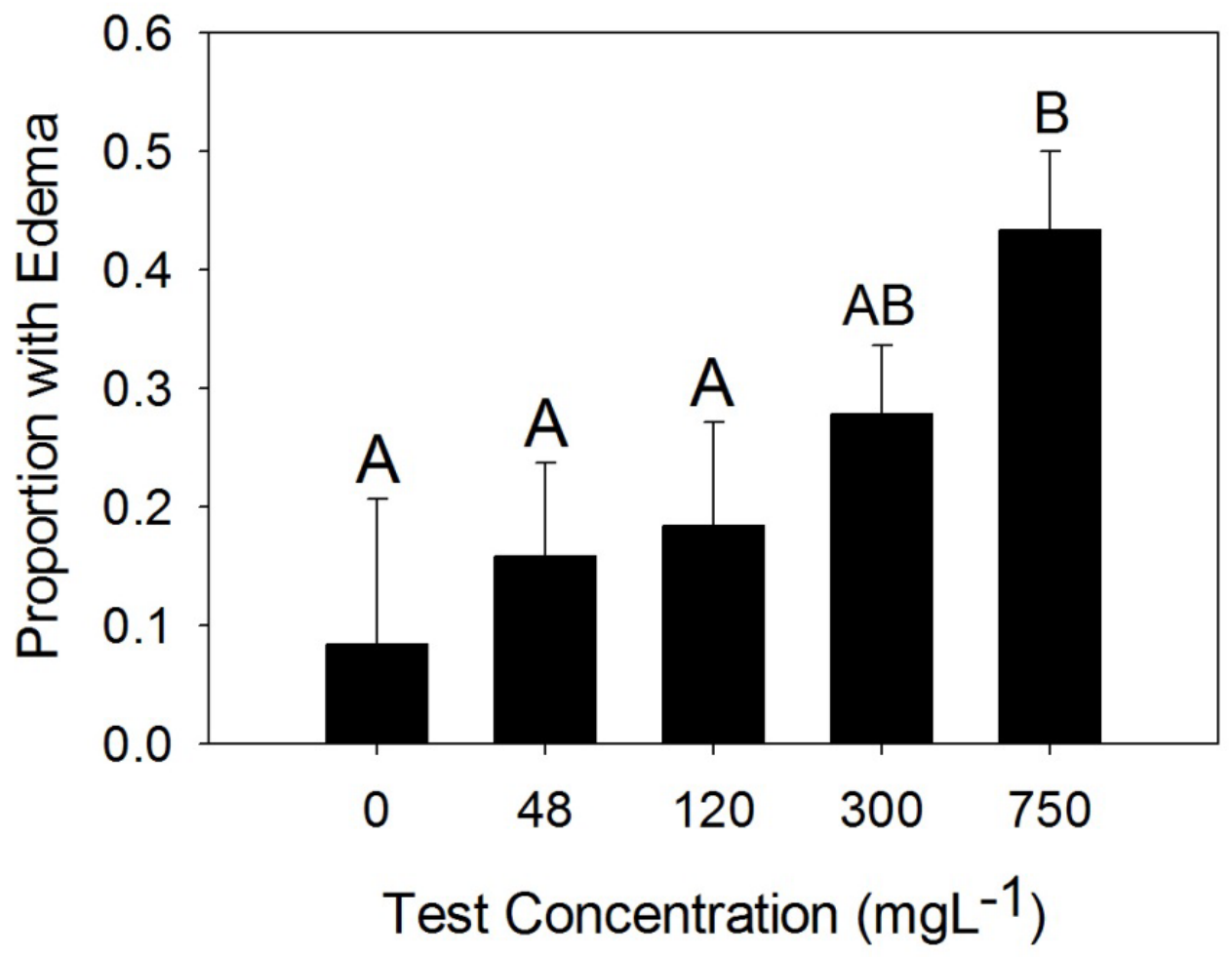

Figure 3.5: Mean proportion of L. sylvatica larvae exhibiting abdominal edema in each test concentration with letter indicating significantly different groups. Error bars represent \pm 2 S.E. 


\section{Environmental Concentrations}

Analysis of chloride concentrations in roadside wetlands and vernal pools revealed variation in concentrations in the local environment. Chloride concentrations in local wetlands and vernal pools ranged from 0.0015 to $18.94 \mathrm{mgL}^{-1}$ (mean $=2.115$, $\max$ 128.5). Chloride concentrations were highest in late summer (August, Figure 3.6). However, chloride concentrations were not significantly different across $(\mathrm{H}=4.9432$, $\mathrm{df}$ $=5, \mathrm{P}=0.422)$ or between sample months $(\mathrm{P}>0.05$ for all tests $)$.

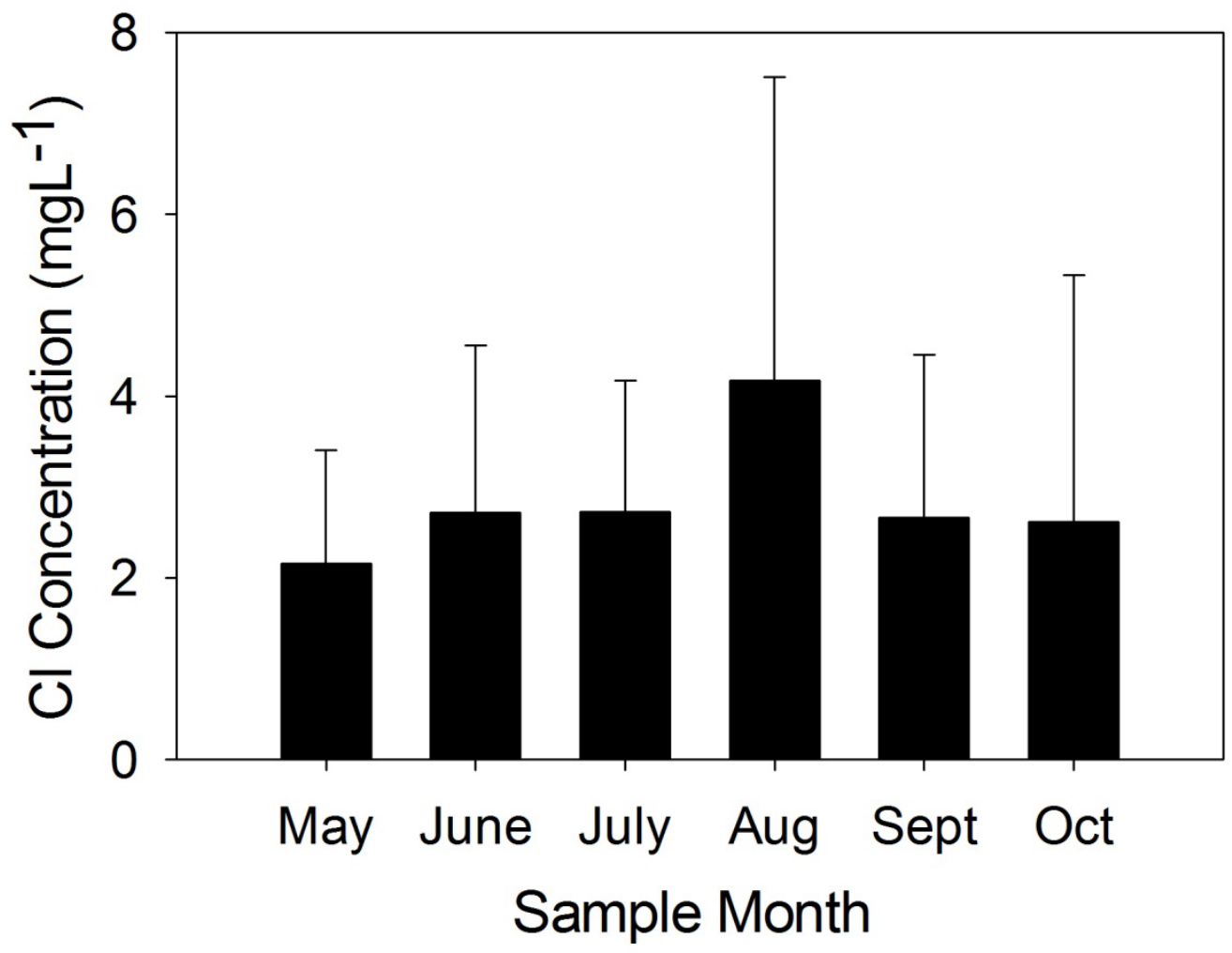

Figure 3.6: Mean environmental concentration of $\mathrm{Cl}^{-}$in wetlands and vernal pools during the amphibian breeding season. Error bars represent \pm 2 S.E. 


\section{Discussion}

Chronic exposure to low concentrations of road salt $(\mathrm{NaCl})$ did not affect survival of either Lithobates sylvatica or L. clamitans in this study. Survival for both species remained high ( $>80 \%$ for $L$. sylvatica and $>50 \%$ for $L$. clamitans) across the exposure concentrations, slightly below the natural survival estimates for L. sylvatica (95-98\%, Siegal 1983). Two studies have examined the effects of chronic exposure to low concentrations of $\mathrm{NaCl}$ with native amphibian species (Karraker 2007a,b; Sanzo and Hecnar 2006). Karraker (2007a) observed a significant decrease in survival of both $L$. sylvatica $(<20 \%)$ and Ambystoma maculatum ( $<11 \%)$ larvae in long-term exposure to $\mathrm{NaCl}$ concentrations above $945 \mathrm{mgL}^{-1}$, respectively, yet survival in L. clamitans remained above $90 \%$ in embryos and larvae exposed to $\mathrm{NaCl}$ concentrations from 0 to $465 \mathrm{mgL}^{-1}$ decreasing to $87 \%$ at $945 \mathrm{mgL}^{-1}$. Additionally, Sanzo and Hecnar (2006) found decreased survival $(<5 \%)$ in L. sylvatica exposed to $\mathrm{NaCl}$ concentrations above $1030 \mathrm{mgL}^{-1}$ whereas survival was $<20 \%$ in the control, 0.39 , and $77.50 \mathrm{mgL}^{-1}$ treatments. The variability in these studies may be attributed to differences in the life stage and length of exposure periods. Karraker (2007b) used both embryonic and larval amphibians in a 70 day exposure, whereas Sanzo and Hecnar (2006)used larvae in a 90 day exposure. The use of only larval L. sylvatica and L. clamitans for longer time periods (100 and 300 days) in this study suggests that larvae in this area may be tolerant to long term $\mathrm{NaCl}$ exposure than other populations. Furthermore, exposure to high salinity may slow or halt development, as well as cause deformities (Gosner and Black 1957; Gomez-Mestre et al. 2004). Exposure to $\mathrm{NaCl}$ did not affect size of larval L. sylvatica nor the number days to complete metamorphosis in this study. We would expect L. sylvatica to decrease time to metamorphosis resulting in smaller size at metamorphosis when exposed to high $\mathrm{NaCl}$ concentrations, as observed by Sanzo and Hecnar (2006).

Wood frog larvae in this study completed metamorphosis in a shorter amount of time (mean $=65$ days, range: $37-90$ ) than observed in other studies on chronic effects of salt exposure (77 days, range 65-81; Sanzo and Hecnar 2006). In terms of size at metamorphosis, our results are similar to that of Karraker (2007a) in which neither larvae 
of L. sylvatica nor A. maculatum differed in size during long-term exposure to $\mathrm{NaCl}$. However, our results for L. clamitans support the hypothesis that $\mathrm{NaCl}$ exposure may accelerate development leading to smaller adults in that we observed the largest individuals (TL) in the control at the end of 300 days. This discrepancy is most likely due to the developmental differences between these species. Wood frogs larvae developing in vernal pools and shallow wetlands must metamorphose quickly in order to survive the variable hydroperiods in these water bodies. Hence these larvae will limit their time of exposure to potentially harmful salt concentrations. In contrast, anurans with larval periods of over one year will potentially be exposed to higher salt concentrations for a longer period. This would result in late and significant effects on adult fitness such as decreased size.

The developmental plasticity of $L$. clamitans may help to explain its tolerance for acute exposure to high concentrations of $\mathrm{NaCl}$ (Karraker 2007b). Evidence of significant differences in total length (TL) but not in body size (SVL) suggests that the tail size in $L$. clamitans may be affect by $\mathrm{NaCl}$ exposure. Predation risk may induce a number of morphological, behavioral and developmental changes in larval amphibians. L. clamitans tadpoles are known to exhibit plasticity of developmental traits (e.g., tail size or shape, behavior, growth, and time to complete metamorphosis; Relyea 2001). Smaller tail size may decrease the ability of these larvae to escape from predators. In addition to physiological stress, these effects could cause serious lethal ramifications for overwintering tadpoles exposed to $\mathrm{NaCl}$.

Sanzo and Hecnar (2006) estimated the median lethal concentration $\left(\mathrm{LC}_{50}\right)$ from 96 hours of exposure between 2636 and $5109 \mathrm{mgL}^{-1}$. The low $\mathrm{NaCl}$ concentrations used in this experiment are well below the $\mathrm{NaCl} \mathrm{LC} \mathrm{LC}_{50}$ estimates for this population of L. sylvatica (7560 $\mathrm{mgL}^{-1}$; Harless et al. 2011) suggesting that test concentrations may be too low to observe significant effects on survival during long term exposure in this population. Furthermore, test concentrations used in this study were greater than environmental 
concentrations in the local area suggesting that local amphibian larvae are not at risk of exposure to $\mathrm{Cl}^{-}$levels beyond their tolerance level.

The presence of both edema and physical abnormalities also differed between these two species. Edema in larval anurans indicates a failure of the renal system and is a physiological response to a variety of stressors, including environmental factors, diseases (Pessier 2009), pesticide exposure (Howe et al. 1998), and exposure to $\mathrm{NaCl}$ (Karraker 2007b). I observed a high incidence of edema in the wood frog larvae exposed to $\mathrm{NaCl}$ above $750 \mathrm{mgL}^{-1}$ whereas no green frog larvae exhibiting edema. In contrast, Karraker (2007b) observed a high percentage (92\%) of edema in newly hatched L. clamitans. Larvae with edema were sluggish and buoyant, and thus more likely to be consumed by a predator. This increased predatory risk in exposure to low $\mathrm{NaCl}$ concentrations may have severe implications for juvenile recruitment in this population. The majority of deformities occurred at the highest salt concentration for L. sylvatica but in the control treatment in the L. clamitans experiment supporting the hypothesis that green frog larvae are more tolerant of $\mathrm{NaCl}$ exposure than wood frogs. Karraker and Ruthig (2009) observed higher incidence of malformations in A. maculatum but not L. clamitans larvae at high $\mathrm{NaCl}$ exposure. In addition, the low rate of overall deformities in this study is similar to rates found in previous studies of long-term $\mathrm{NaCl}$ exposure to larval amphibians (reviewed in Karraker 2007a).

Analysis of chloride levels in roadside water bodies indicates a low level of persistent $\mathrm{Cl}^{-}$ as a result of road salt application in the local area. The maximum chloride concentration observed in this study $\left(128.5 \mathrm{mgL}^{-1}\right)$ is much lower than observed in other studies in which maximum concentrations of 586 (Collins and Russell 2009), 945 (Karraker 2007a) 1,030 (Sanzo and Hecnar 2006), 4,629 (Kaushal et al. 2005), and 18,000 $\mathrm{mgL}^{-1}$ (Environment Canada 2001) were observed. I did however observe a similar temporal trend in chloride concentration with highest chloride concentrations in both early spring and again in late summer as noted in previous studies (Godwin et al. 2003; Kaushal et al. 2005; Karraker 2007b; Collins and Russell 2009). These peaks in chloride occur at 
critical periods of amphibian development. Increased temperatures and snowmelt in spring triggers breeding activity in wood frogs (L. sylvatica; Stebbins and Cohen 1995). Embryonic wood frogs and overwintering L. clamitans larvae are at risk of this exposure in early spring. Furthermore, chloride peaks in late summer may have negative impacts on larvae of both species, particularly for $L$. sylvatica that are likely to be completing metamorphosis during this time (Karraker 2007a).

One study has examined the chloride concentration of streams in winter and found a significant increase in chloride during heavy road salt application periods. Kaushal et al. (2005) noted the highest maximum chloride concentrations in urban streams in winter compared to all other seasons. This indicates the potential for high chloride outside of the time periods examined in this study. These high levels may present a significant stressor to amphibian larvae that overwinter, such as those of $L$. clamitans.

In summary, the larvae of these two amphibians responded very differently to exposure to sublethal concentrations of $\mathrm{NaCl}$. Lithobates clamitans appears to be more tolerant of high concentrations of $\mathrm{NaCl}$ yet prolonged exposure through a lengthy larval period may have significant fitness costs. The high occurrence of edema in L. sylvatica larvae suggests that even brief $\mathrm{NaCl}$ exposure is a significant physiologic stressor to these rapidly developing larvae. While persistent $\mathrm{Cl}^{-}$in the local area remains low, I cannot assume a lack of effect of prolonged exposure to native amphibians. Future work should address this relationship in an effort to shed more light onto the species differences in sensitivity to $\mathrm{NaCl}$ exposure.

\section{Acknowledgements}

I am indebted to R. Alger, P. Nankervis, M. Mitchell, H. List, E. Gorsalitz, E. Rogers, N. DelPiccolo, K. Griffith, and R. Datta for assistance in both field and laboratory portions of the experiment. Funding for this research was provided by grants from the DeVlieg Foundation, the Chicago Herpetological Society, the Western New York Herpetological Society, the Amphibian Specialist Group of the International Union for Conservation of 
Nature and Natural Resources, the Ecosystem Science Center at Michigan Technological University, with support from the MTU Global Watershed GK-12 program. This research has also been supported by funding and infrastructure provided by Michigan Technological University. Embryos and larvae were collected under permissions granted by the Keweenaw Bay Indian Community Department of Natural Resources. I conducted laboratory research under permit by Michigan Technological University (IUCAC permit L01401).

\section{References}

Benbow ME, Merritt RW. 2004. Road-salt toxicity of select Michigan wetland macroinvertebrates under different testing conditions. Wetlands. 24:68-76.

Collins SJ, Russell RW. 2009. Toxicity of road salt to Nova Scotia amphibians. Environmental Pollution. 157:320-324.

Conant R, Collins JT. 1998. A Field Guide to Reptiles and Amphibians: Eastern and Central North America. 3rd ed. Boston (MA): Houghton Mifflin Company. 450 p.

D'Itri FM. 1992. Prologue. In: D'Itri FM, editor. Chemical Deicers and the Environment. 1st ed. Boca Raton (FL): Lewis Publishing. P. v-xv.

Dougherty CK, Smith GR. 2006. Acute effects of road-deicers on the tadpoles of three anurans. Applied Herpetology. 3:87-93.

Environment Canada. 2001. Priority substances list assessment report: Road-salts. Ministry of Public Works and Government Services. Ottawa, Ontario, Canada.

Findlay SEG, Kelly VR. 2011. Emerging indirect and long-term road salt effects on ecosystems. Annals of the New York Academy of Sciences. 1223:58-68. 
Forman RTT, Sperling D, Bissonette JA, Clevenger AP, Cutshall CD, Dale VH, Fahrig L, France R, Goldman CR, Heanue K, Jones JA, Swanson FJ, Turrentine T, Winter TC. 2003. Road Ecology Science and Solutions. 1st ed. Washington (DC): Island Press. 504 p.

Forman RTT, Alexander L. 1998. Roads and their major ecological effects. Annual Review of Ecological Systems. 29:207-31.

Godwin KS, Hafner SD, Buff MF. 2003. Long-term trends in sodium and chloride in the Mohawk River, New York: the effect of fifty years of road-salt application.

Environmental Pollution. 124:273-281.

Gomez-Mestre I, Tejedo M, Ramayo E, Estepa J. 2004. Developmental alterations and osmoregulatory physiology of a larval anuran under osmotic stress. Physiological and Biolgeochemical Zoology. 77:267-274.

Gosner KL. 1960. A simple table for staging anuran embryos and larvae with notes on identification. Herpetologica. 16:183-190.

Gosner KL, Black IH. 1957. The effects of acidity on the development and hatching of New Jersey frogs. Ecology. 38:256-262.

Harless ML, Huckins CJ, Grant JB, Pypker TG. 2011. Effects of six chemical deicers on larval wood frogs (Rana sylvatica). Environmental Toxicology and Chemistry. 30:16371641.

Hoffman RS, Capel PD, Larson SJ. 2000. Comparison of pesticides in eight U.S. urban streams. Environmental Toxicology and Chemistry. 19:2249-2258. 
Howe GE, Gillis R, Mowbray RC. 1998. Effect of chemical synergy and larval stage on the toxicity of atrazine and alachlor to amphibian larvae. Environmental Toxicology and Chemistry. 17:519-525.

Karraker NE. 2007a. Investigation of the amphibian decline phenomenon: Novel smallscale factors and a large-scale overview. PhD thesis. State University of New York, Syracuse, NY.

Karraker NE. 2007b. Are embryonic and larval green frogs (Rana clamitans) insensitive to road deicing salt? Herpetological Conservation and Biology. 2:35-41.

Karraker NE, Gibbs JP, Vonesh JR. 2008. Impacts of road de-icing salt on the demography of vernal pool-breeding amphibians. Ecological Applications. 18:724-734.

Karraker NE, Ruthig GR. 2009. Effect of road deicing salt on the susceptibility of amphibian embryos to infection by water molds. Environmental Research. 109:40-45.

Kaushal SS, Groffman PM, Likens GE, Belt KT, Stack WP, Kelly VR, Band LE, Fisher GT. 2005. Increased salinization of fresh water in the northeastern United States. Proceedings of the National Academy of Sciences USA. 102:13517-13520.

National Oceanic and Atmospheric Administration (NOAA) [Internet]. 2011. National Climate Data Center. Average Snowfall Record for Marquette, Michigan from 19462011; [updated 2008 Aug 20, cited 2012 Jan 8]. Available from: http://lwf.ncdc.noaa.gov/oa/climate/online/ccd/snowfall.html

National Research Council. 1991. Highway Deicing: Comparing Salt and Calcium Magnesium Acetate. Special Report 235. National Research Council, Washington, DC, USA. 
Pauley TK, Lannoo MJ. 2005. Rana clamitans Latreille (1801) Green Frog. In: M Lannoo, editor. Status and Conservation of North American Amphibians. 1st ed. Berkeley (CA): University of California Press. p. 549-552.

Pessier AP. 2009. Edematous frogs, urinary tract disease, and disorders of fluid balance in amphibians. Journal of Exotic Pet Medicine. 18:4-13.

R Development Core Team. 2010. R: A Language and Environment for Statistical Computing, version 2.11.1. R. Foundation for Statistical Computing. Vienna, Austria.

Ramakrishna D, Viraraghavan T. 2005. Environmental impact of chemical deicers- a review. Water, Air, and Soil Pollution. 166:49-63.

Relyea RA. 2001. Morphological and behavioral plasticity of larval anurans in response to different predators. Ecology. 82:523-540.

Sanzo D, Hecnar SJ. 2006. Effects of road de-icing salt $(\mathrm{NaCl})$ on larval Wood frogs (Rana sylvatica). Environmental Pollution. 140:247-56.

Seigel RA. 1983. Natural survival of eggs and tadpoles of the wood frog, Rana sylvatica. Copeia. 1983:1096-1098.

Stebbins RC, Cohen NW. 1995. A Natural History of Amphibians. 1st ed. Princeton (NJ): Princeton University Press. 316 p.

Turtle SL. 2000. Embryonic survivorship of the spotted salamander (Ambystoma maculatum) in roadside and woodland vernal pools in southeastern New Hampshire. Journal of Herpetology. 34:60-67. 


\title{
Chapter 4: An Analysis of Chloride Concentrations in Surface Water Bodies in Michigan's Upper Peninsula
}

\begin{abstract}
The impacts of roads on surrounding terrestrial and freshwater ecosystems may be quantified through the identification of a road effect zone. This represents the area adjacent to the roadway in which significant impacts on the survival or health of wildlife species may occur. Amphibians experience negative effects on fitness when using these water bodies while exposed to elevated chloride levels. I use the road effect zone concept to identify water bodies near roads that receive road salt $(\mathrm{NaCl})$ that contain elevated levels of $\mathrm{Cl}$ that may impact breeding amphibians. I measured residual chloride concentrations in 137 surface water bodies close to and far from a salt treated highway in the three northernmost counties of Michigan's Upper Peninsula from May to September of 2009. Chloride concentrations were significantly higher in waters within $40 \mathrm{~m}$ of this highway and varied throughout the amphibian breeding season with the highest levels measured in late summer (range: $0-18.3 \mathrm{mgL}^{-1}$ ). While these levels were lower than in previous studies, larval amphibians in these wetlands may experience substantial sublethal impacts on fitness (Chapter 3). The acreage of palustrine wetlands impacted by road salt application in these three counties was highest in Houghton County when using a buffer of $40 \mathrm{~m}$ as well as a conservative estimate of $250 \mathrm{~m}$. Management efforts should focus on the protection of surface waters near salt-treated highways through reduced salt zones or other non-chemical methods of reducing $\mathrm{NaCl}$ application.
\end{abstract}

\section{Keywords}

road salt, de-icing salt, water quality, chloride, road-effect zone, amphibians 


\section{Introduction}

Substantial negative impacts of roads on wildlife populations has been documented in a variety of species ranging from ground beetles and grizzly bears to amphibians (reviewed in Eigenbrod et al. 2009). Road density in the United States is increasing yearly, leaving fewer and fewer tracts of road-less area in states such as Michigan (Figures 4.1 and 4.2). A high density of roads may have substantial negative impacts on local wildlife species. The primary ecological effects of roads on surrounding habitats are from habitat loss or transformation, pollution, avoidance, mortality (from traffic and predation), and the corridor effect (reviewed in Jaeger et al. 2005). Of these effects, road-based pollutants are considered a serious threat to terrestrial and aquatic ecosystems (Trombulak and Frissell 2000). Chemicals used in road deicing activities are recognized as a major contributor to habitat transformation and pollution as a growing threat to ecosystem health (Environment Canada 2001; Ramakrishna and Viraraghavan 2005).

Increasing and widespread use of sodium chloride $(\mathrm{NaCl})$ as a deicing agent in cold climates of North America over the past 60 years has resulted in elevated chloride levels in surface water bodies (Kaushal et al. 2005). $\mathrm{NaCl}$ is the most common de-icing agent in the United States due to its low cost and availability at a number of salt mines across the country (Forman et al. 2003). $\mathrm{NaCl}$ use nationwide is estimated at 10 million tons (D'Itri 1992), ranging from 0.3 to 17.6 tons per lane mile across 26 states (National Research Council 1991). The Great Lakes region receives the highest amount of salt, with Michigan receiving the most $\mathrm{NaCl}$ with an average of 12.9 tons per lane-mile (National Research Council 1990). The three northernmost counties of Michigan's Upper Peninsula (Figure 4.2) use a 19:1 mixture of sand to salt. The annual salt load estimates on primary roads in Baraga and Keweenaw counties, as well as on all roads in Houghton County are much lower than the state average (Table 4.1). 


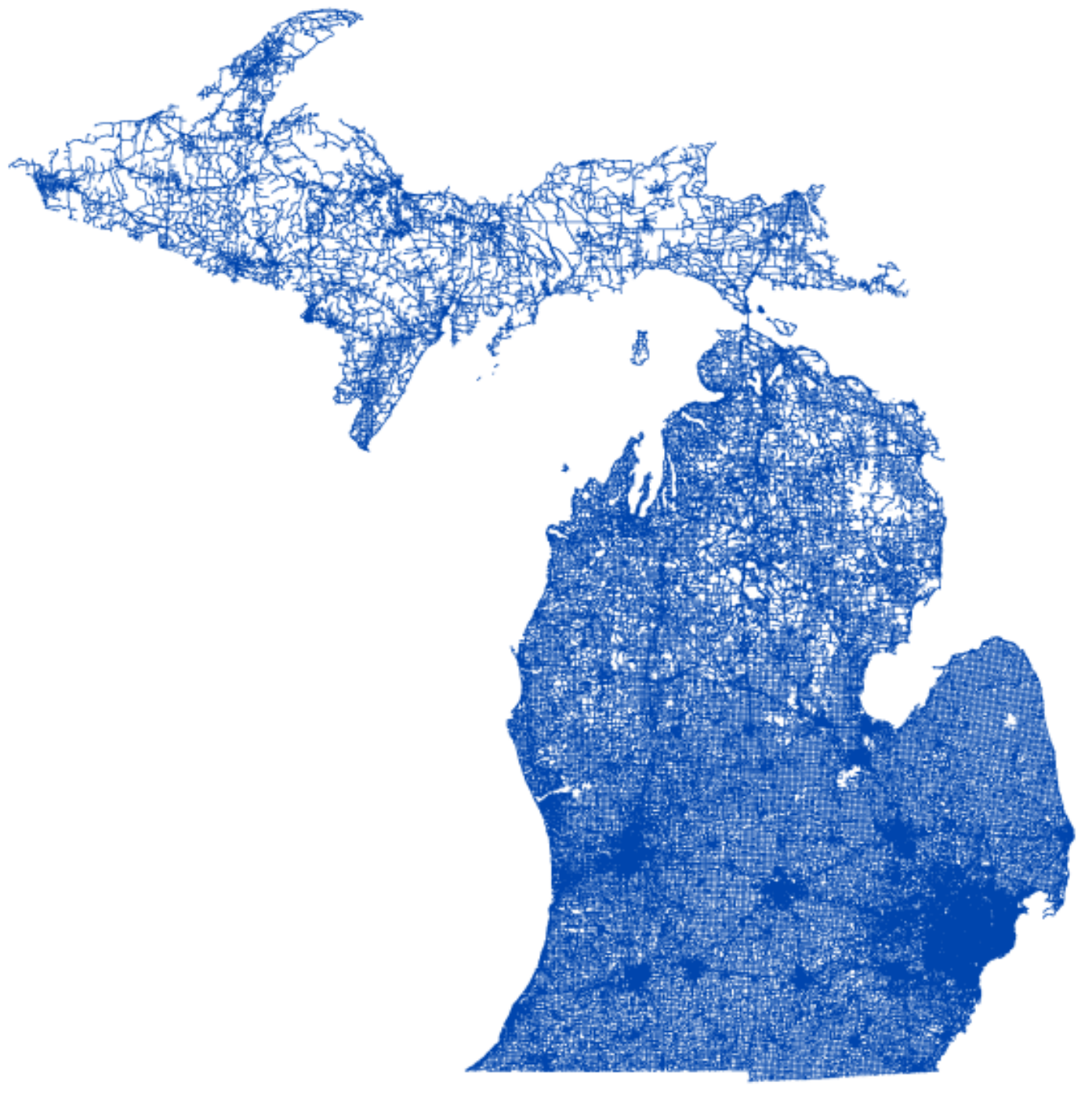

Figure 4.1: Density of roadways in the upper and lower peninsulas of Michigan, U.S.A. 


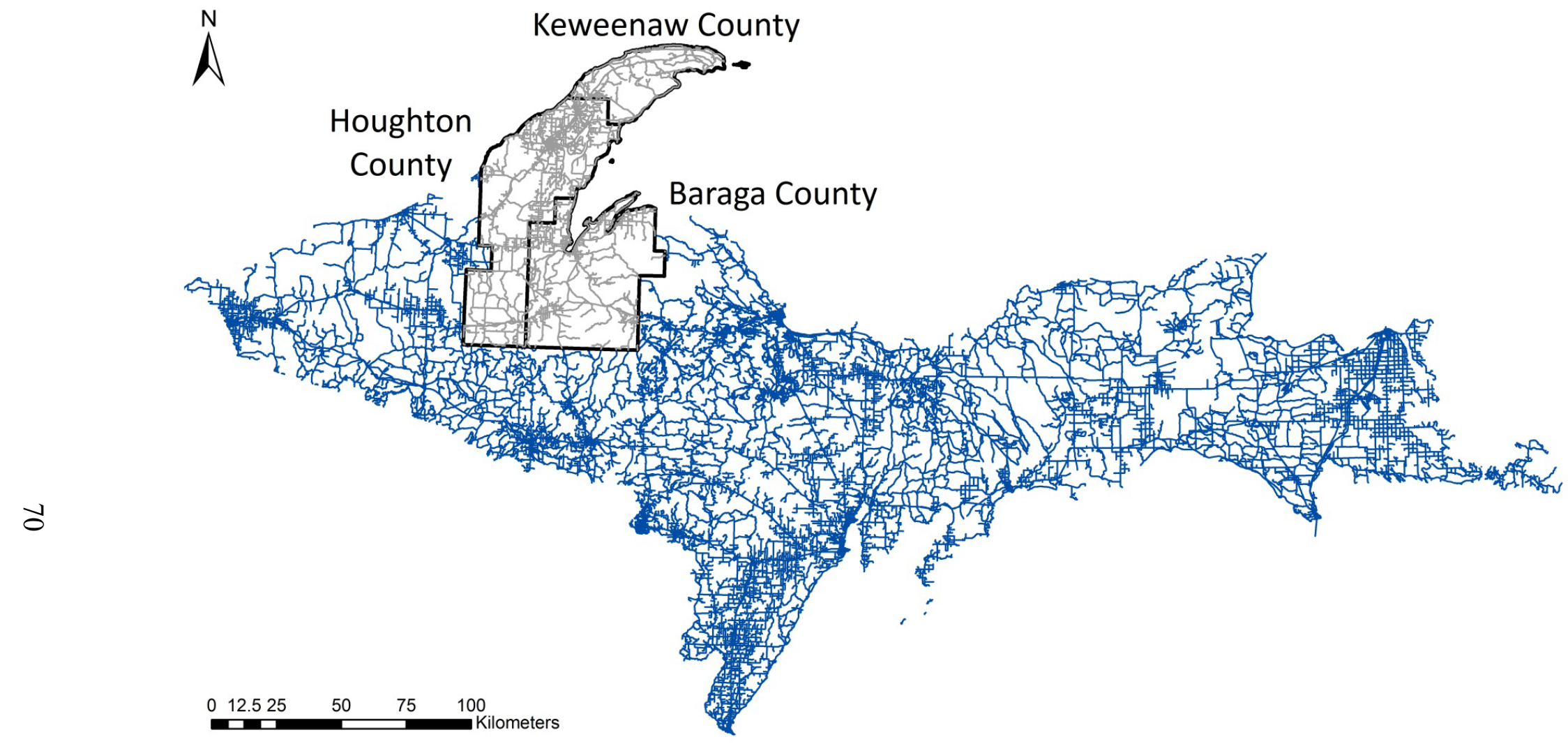

Figure 4.2: Density of roadways in Michigan's Upper Peninsula highlighting the roads in the focal region in this study (grey lines): Baraga, Houghton, and Keweenaw Counties (black outline). 


\section{Table 4.1}

Average salt $(\mathrm{NaCl})$ and sand use on county and state roads in Baraga, Houghton, and Keweenaw counties of Michigan.

\begin{tabular}{|c|c|c|c|c|c|}
\hline County & Roads & $\begin{array}{c}\text { Primary } \\
\text { Roads } \\
\text { (lane miles) } \\
\end{array}$ & $\begin{array}{c}\text { Sand Used } \\
\text { (tons) }\end{array}$ & $\begin{array}{c}\mathrm{NaCl} \text { Used } \\
\text { (tons) }\end{array}$ & $\begin{array}{c}\mathrm{NaCl} \mathrm{Per} \\
\text { Lane Mile } \\
\text { (tons) }\end{array}$ \\
\hline \multirow{2}{*}{ Baraga $^{a, b}$} & County & 156 & 15,842 & 634 & 2.56 \\
\hline & State & 245 & - & 6,410 & 26.16 \\
\hline \multirow{2}{*}{ Houghton $^{\mathrm{b}, \mathrm{c}}$} & County & 247 & 18,000 & 637 & 1.61 \\
\hline & State & 160 & - & 5,191 & 32.44 \\
\hline \multirow{2}{*}{ Keweenaw $^{\mathrm{d}, \mathrm{e}}$} & County & 112 & 8,316 & 504 & 5.10 \\
\hline & State & 91 & - & - & - \\
\hline
\end{tabular}

${ }^{\mathrm{a}}$ D.J. Mils, Baraga County Road Commission, pers comm.

${ }^{\mathrm{b}}$ J. Lake, Michigan Department of Transportation (MDOT), pers comm.

${ }^{\mathrm{c}}$ Houghton County Road Commission Factsheet.

${ }^{\mathrm{d}}$ G.M. Patrick, Keweenaw County Road Commission, pers comm.

${ }^{\mathrm{e}}$ Total salt use by county including state highways. 
The environmental damage from $\mathrm{NaCl}$ application arises from the accumulation of chloride in roadside soils and water bodies. Once applied, $\mathrm{NaCl}$ is readily transported into the roadside environment and temporarily held within the soil. Sodium ions are taken up in the soil whereas chloride ions are not subject to natural removal mechanisms (Lunmark and Olofsson 2007). The resultant $\mathrm{Cl}^{-}$is transported to nearby surface waters where it may eventually accumulate in the groundwater (Environment Canada 2001). Chloride contamination of surface water bodies in the United States is well documented (Godwin et al. 2003; Kaushal et al. 2005). The US Environmental Protection Agency considers an average chloride concentration of $230 \mathrm{mgL}^{-1}$ over a four day period to be harmful to aquatic life (USEPA 1988). Environment Canada considers prolonged exposure to chloride concentrations above $220 \mathrm{mgL}^{-1}$ to be harmful to aquatic organisms. However, chloride levels in excess of $4000 \mathrm{mgL}^{-1}$ in roadside ponds and $18000 \mathrm{mgL}^{-1}$ in urban areas have been observed (Environment Canada 2001). The range of minimum chloride concentrations that produce negative impacts on freshwater organisms range from 0.5 to $1,500 \mathrm{mgL}^{-1}$ (reviewed in Findlay and Kelly 2011). These ranges suggest that freshwater organisms vary greatly in their tolerance of $\mathrm{Cl}^{-}$concentrations. This highlights the importance of monitoring $\mathrm{Cl}^{-}$concentrations in surface water bodies in order to characterize the potential negative impacts of $\mathrm{NaCl}$ application.

The ecological effects of a road on the surrounding habitat may be quantified using a road-effect zone. Forman and Alexander (1998) introduced the concept of a road-effect zone as a defined distance from a roadway in which substantial negative ecological impacts on a species are observed. Thus far, six studies have attempted to quantify this zone to define the direct and indirect effects of roads on the surrounding ecosystem (Table 4.2). Estimates produced in these studies suggest the road-effect zone ranges from $35-1000 \mathrm{~m}$ from the road, depending on the species and metric of analysis. 
Table 4.2

Results of studies quantifying the road-effect zone for a variety of organisms.

\begin{tabular}{lccl}
\hline Focal Species & Metric & Road-effect & Estimate $(\mathrm{m})$ \\
\hline Forest Birds & Habitat quality & $<200$ & Reijnen et al. 1995 \\
\hline Forest and & Abundance & 930 & \\
$\begin{array}{l}\text { Grassland Birds } \\
\text { Invasive plants }\end{array}$ & Survival & 100 & Forman and Deblinger 2000 \\
Moose & Home range & 300 & \\
Deer & Abundance & 300 & \\
\hline Desert Tortoises & Abundance & 400 & Boarman and Sazaki 2006 \\
\hline Salamanders & Abundance & 35 & Semlitsch et al. 2007 \\
\hline Frogs and & Abundance & 50 & Karraker 2007 \\
Salamanders & & & Eigenbrod et al. 2009 \\
\hline Frogs & Species richness & $250-1000$ & \\
\hline
\end{tabular}

The road-effect concept may be applied to studying the indirect effects of road salt contamination by examining chloride concentrations in roadside water bodies. The goal of this study is to quantify the relationship between chloride concentration and distance to the nearest salt treated road in the northern most three counties of Michigan's Upper Peninsula. This area has a high density of perennial wetlands with few heavily traveled roads, making it an ideal location to investigate this question (Figure 4.3). I expect to see a negative relationship between distance from salt-treated roadway and chloride concentrations. In addition, I anticipate that chloride concentrations in roadside pools to meet or exceed threshold levels for lethal and sublethal effects of $\mathrm{NaCl}$ on local amphibian species (Chapters 2 and 3 ). 
$N$

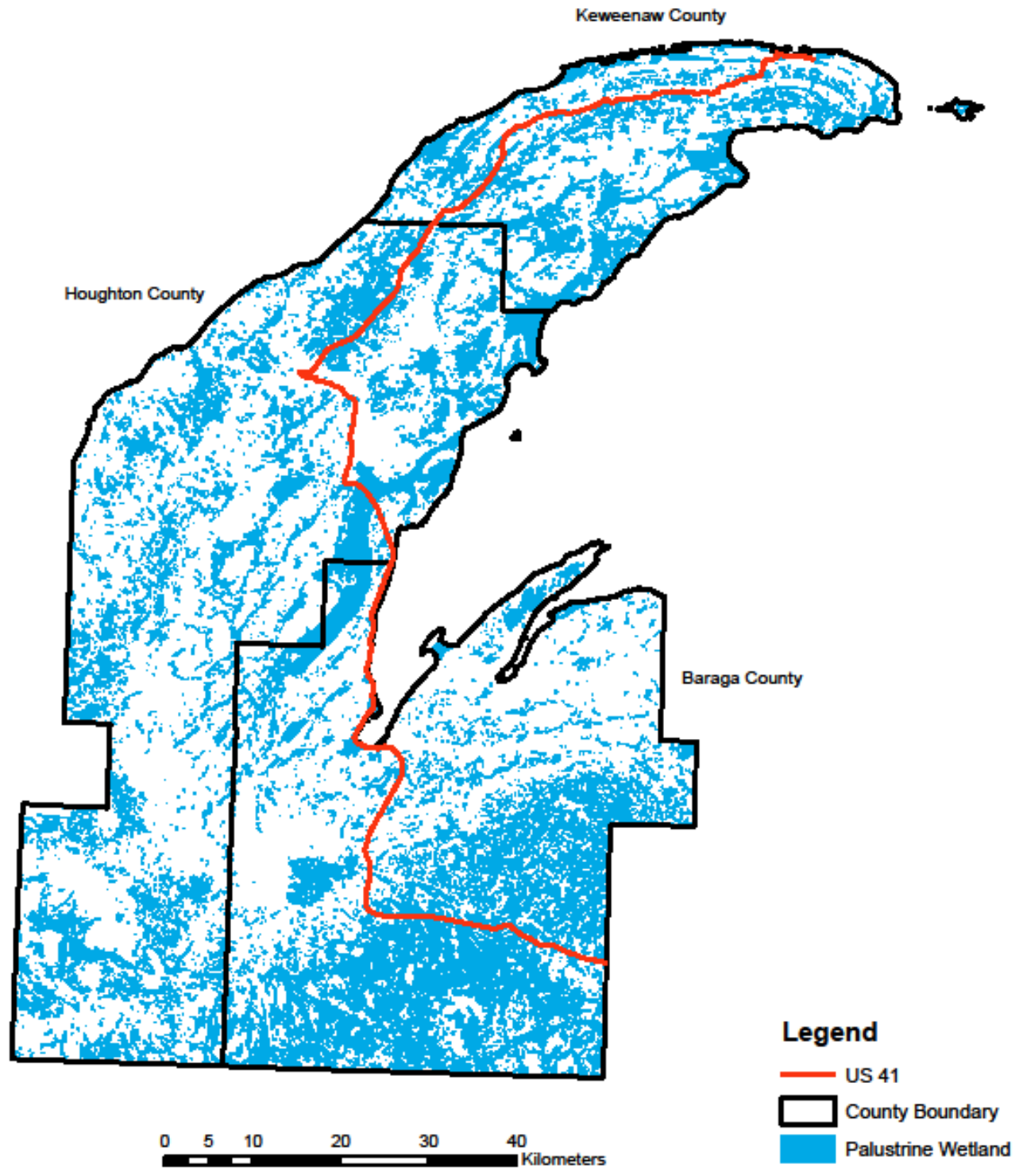

Figure 4.3: Density of palustrine wetlands in Baraga, Houghton, and Keweenaw Counties of Michigan's Upper Peninsula. 


\section{Methods}

To determine the environmentally realistic concentrations of $\mathrm{Cl}^{-}$resulting from road salt application in the local area, I collected water samples from 137 perennial wetlands at varying distances from US 41 across Baraga, Houghton, and Keweenaw Counties in the Upper Peninsula of Michigan throughout the 2009 amphibian breeding season (May through September). These water bodies were on average $3.1 \mathrm{~km}(.005-19.08)$ from a salt-treated highway. I chose to focus our sampling along US 41 it traverses all three northern counties. Water samples were returned to the laboratory and stored at 4[C. I filtered the samples through a $0.45 \mu \mathrm{m}$ cellulose acetate filter and quantified chloride concentration using ion chromatography (Dionex ICS-900, AS22 4 mm column, Fisher Scientific Inc., Sunnyvale CA). I used ArcGIS to measure the distance from the water sample collection location to the nearest edge of a salt-treated roadway and for the following geoprocessing analysis (ESRI 2011).

Chloride concentration remained non-normally distributed even after multiple transformations in both years using the Shapiro-Wilk test for normality for the distribution of variables. I used the nonparametric Kruskal-Wallis one way analysis of variance test to examine differences in chloride concentration across sample months with multiple post hoc comparisons to test for differences between months (R package 'pgirmess'). To characterize the relationship between $\mathrm{Cl}^{-}$concentration and distance to the nearest salt-treated road in local water bodies, I used a linear regression model after a $\log$ transformation of these variables. Analysis of the residuals in normal probability plots of this model did not indicate skewness or a heavy-tailed distribution of the residuals that would affect the fit of our regression model (Montgomery et al. 2006). I removed seven data points from the statistical analysis that were identified as exhibiting severe influence on the model fit by analysis of leverage plots (R package 'car', maximum concentration = $90.2 \mathrm{mgL}^{-1}$ ). These points were collected in the summer (June and July) within $55 \mathrm{~m}$ of US 41. I divided the chloride concentration data into four quartiles using $\mathrm{R}(25,50,75$, and $100 \%$ ) based on the distance from the sample location to the nearest salt-treated highway (US 41). I used the nonparametric Kruskal-Wallis one way analysis of variance test to examine differences in chloride concentration across these distance categories with 
multiple post hoc comparisons to test for differences between different distance categories (R package 'pgirmess').

I obtained spatial data on the infrastructure and hydrology of our study area from the Michigan Center for Geographic Information (CGI; http://www.michigan.gov/cgi/). I chose to use the Department of Natural Resources Wetlands data because it discerned between the lacustrine (formed at the bottom or along the shore of a lake) and palustrine wetlands (inland wetlands that are not affected by the lake). All but the palustrine wetlands were removed from these layers prior to analysis. I obtained data for county boundaries using the CGI framework for political-senate boundaries. Isle Royale was removed from the analysis by subtracting $535.4 \mathrm{~km}^{2}$ (132.3 acres) from the data for Keweenaw County.

The Michigan Framework (version 11) data layer was used to obtain information on the amount and types of roadways in these three counties. To obtain county totals of specific road types I divided the roads as follows according to the Framework Classification Code (FCC) in Appendix D of the metadata for the Michigan All Roads layer: primary roads are coded as FCC A21 or A23, secondary roads as A31-A33, and tertiary or unmanaged roads as A41-A90. For our analysis I used a conservative road-effect zone of $250 \mathrm{~m}$ based on estimates from previous studies on amphibians (Table 4.2). I placed a buffer zone of $40 \mathrm{~m}$ and $250 \mathrm{~m}$ from US 41 across Baraga, Houghton, and Keweenaw Counties. To determine the area of wetlands that are located within this buffer zone, I used the intersect function on the US 41 buffer layer and the palustrine wetlands layer. I used "R: A Language and Environment for Statistical Computing" to perform all statistical analyses with an alpha level of 0.05 (R Development Core Team 2010).

\section{Results}

Water bodies closest to the nearest salt-treated highway contained elevated chloride levels as a result of road salt application (Figures $4.4-4.7$ ). However, the concentration of chloride steadily decreased as distance from the highway increased. Distance from the nearest salt-treated highway significantly predicted chloride concentration in these water 
bodies $\left(b=2.39, \mathrm{t}_{253}=10.07, \mathrm{P}<0.001\right)$ with chloride levels declining as distance from the nearest salt treated road increased (Adjusted $\mathrm{R}^{2}=0.081, \mathrm{~F}_{1,251}=23.19, \mathrm{P}<0.001$ ).Chloride concentrations ranged from 0.0 to $18.3 \mathrm{mgL}^{-1}$ (mean $\left.=1.84\right)$ and were highest within $250 \mathrm{~m}$ of US 41. Chloride concentrations were highest in late summer (August September) and were significantly different across sample months $(H=10.98, d f=4, p-$ value $=0.027)$. Chloride levels increased significantly from May to June $(\mathrm{P}<0.05)$ whereas concentrations were similar in all other months ( $P>0.05$ for all tests). Quantile analysis divided the sampling data into four groups as follows: A: 0-0.40, B: 0.05-0.950, C: $0.960-4.03$, and D: 4.04-19.08 km from US 41. Distance classes had similar sample sizes with 63 samples in classes $A$ and $D$, while classes B and C contained 62 samples. Chloride concentrations in samples within $0.40 \mathrm{~km}$ of the highway were wide ranging and were significantly different across distance categories $(\mathrm{H}=83.50, \mathrm{df}=4$, $\mathrm{p}$-value $=$ $<0.001$ ). Water bodies within $0.40 \mathrm{~km}$ of US 41 had significantly greater chloride concentrations compared to each of those in the remaining distance classes (all $\mathrm{P}<0.05$ ). 


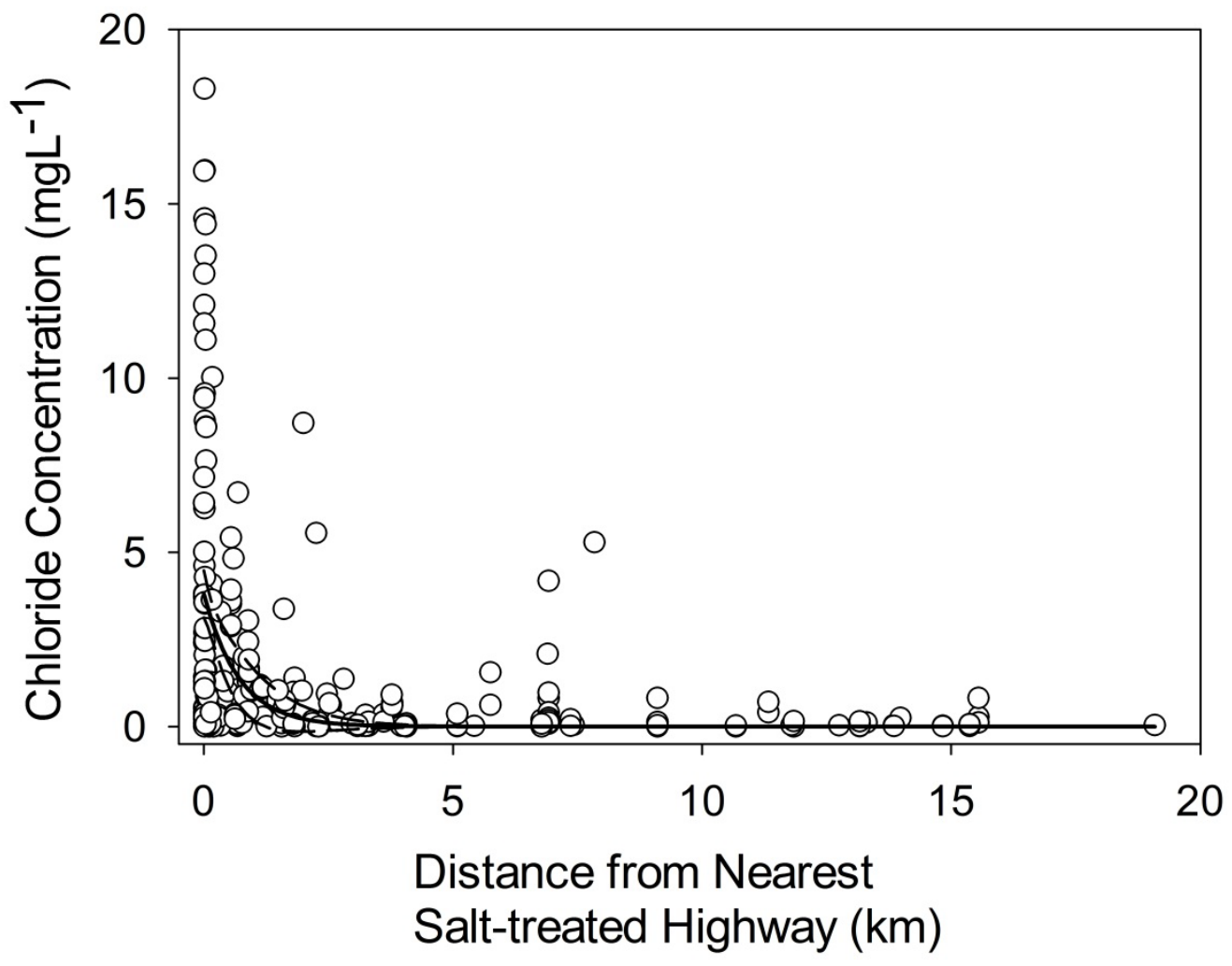

Figure 4.4: Relationship between chloride concentrations in perennial wetlands and distance from the nearest salt treated highway $(\mathrm{N}=253)$ including simple linear regression $(y=2.39-0.208 x)$ with the $95 \%$ confidence bands. 


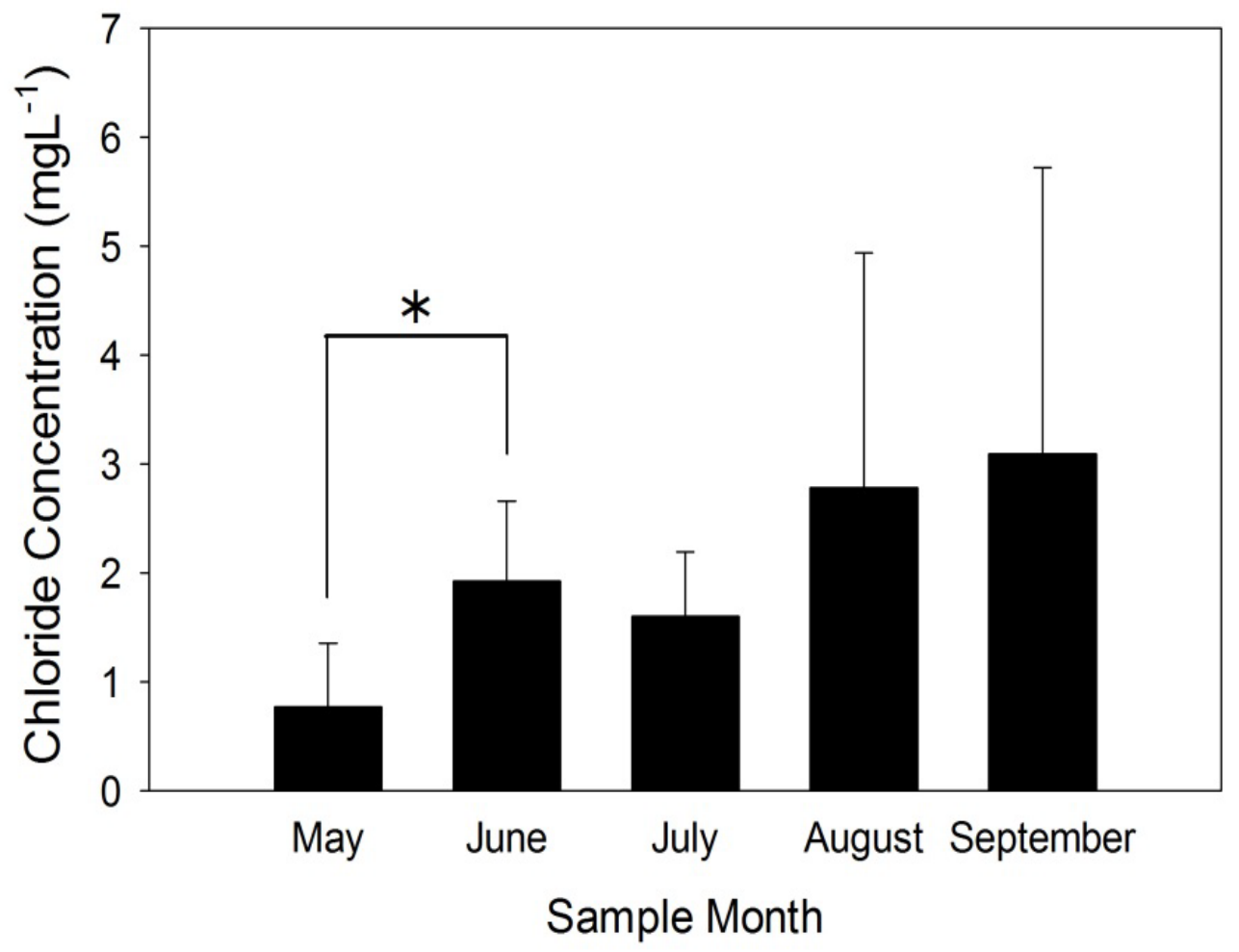

Figure 4.5: Mean environmental concentrations of chloride in surface water bodies during the amphibian breeding season $(\mathrm{N}=253)$. Error bars represent \pm 2 S.E. An asterisk indicates a significant increase of chloride from May to June. 


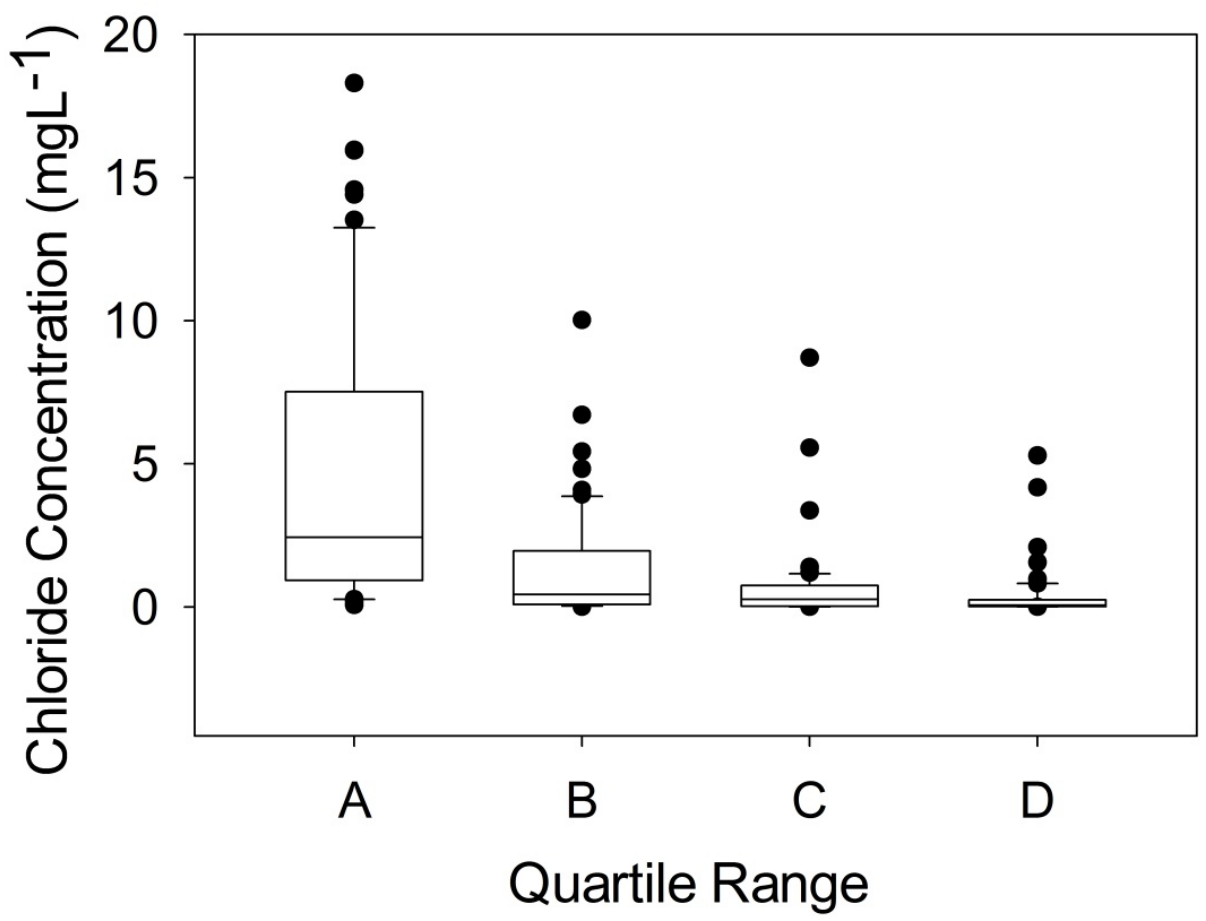

Figure 4.6: Distribution of chloride concentrations $\left(\mathrm{mgL}^{-1}\right)$ in surface water bodies divided into four quartiles based on sample locations (A: 0-0.40, B: 0.05-0.950, C: 0.9604.03, D: 4.04-19.08 km) from US 41 across Baraga, Houghton, and Keweenaw Counties. 


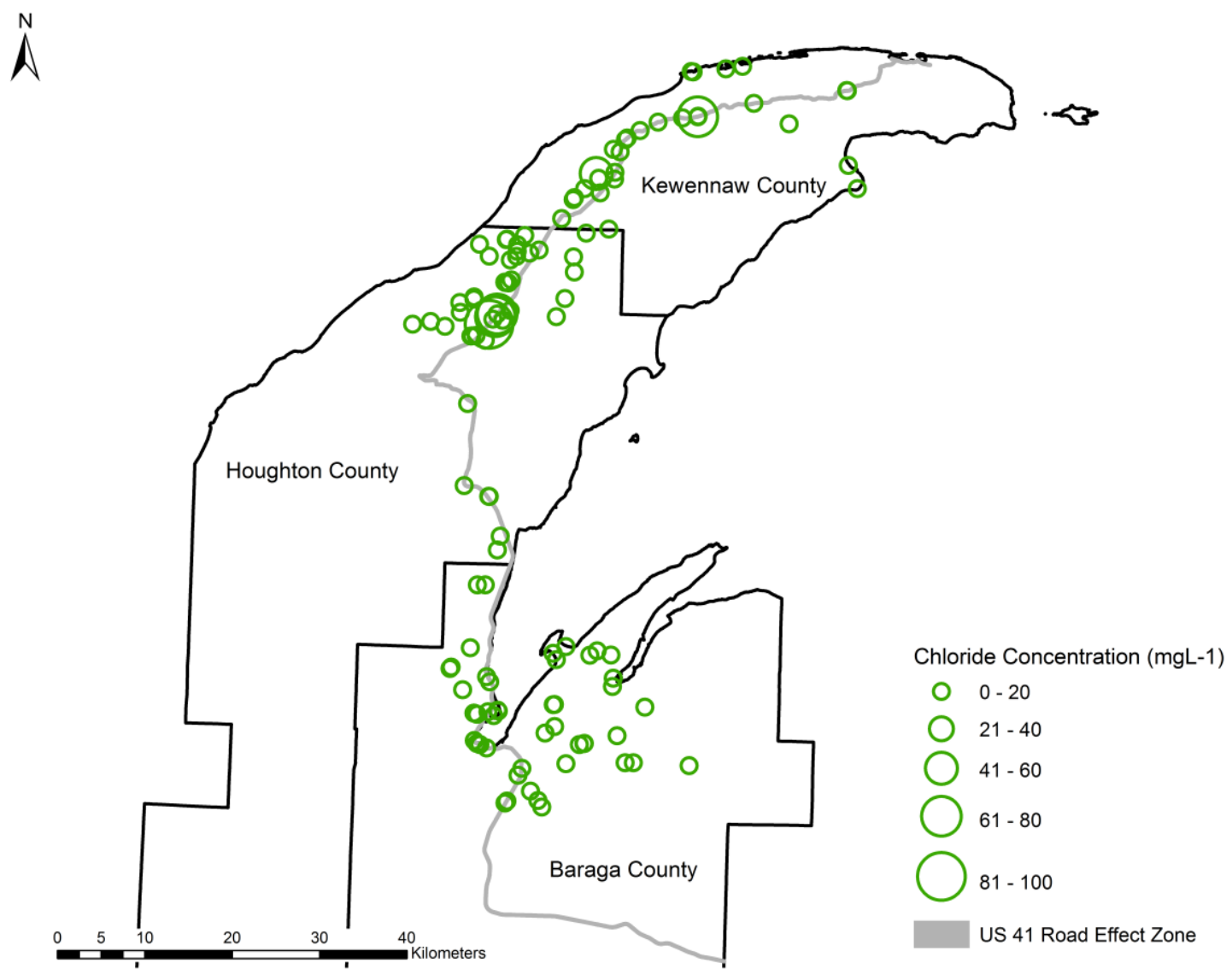

Figure 4.7: Chloride concentration $\left(\mathrm{mgL}^{-1}\right)$ in sample locations in relation to the US 41 road-effect zone $(\mathrm{N}=259)$. 
Houghton County contained the largest amount of roadways including $74 \mathrm{~km}$ of US 41 (Figure 4.8). Baraga and Keweenaw Counties contain a moderate amount of primary roads with each encompassing $53 \mathrm{~km}$ of US 41. Palustrine wetlands covered the largest area in Baraga county (19\%) followed closely by Keweenaw (18\%) and Houghton (13\%) counties (Table 4.3). The $40 \mathrm{~m}$ road-effect zone contained a similar proportion of palustrine wetlands across the three counties $(0.1 \%)$. The $250 \mathrm{~m}$ road-effect zone included the largest proportion of Keweenaw County (3.2\%) compared to Baraga and Houghton counties ( 2.5 and $2.4 \%$, respectively). The proportion of palustrine wetlands within the road-effect zone varied by county and was the highest in Houghton County $(2.5 \%$, Keweenaw $=2.2 \%$, Baraga $=1.9 \%)$.

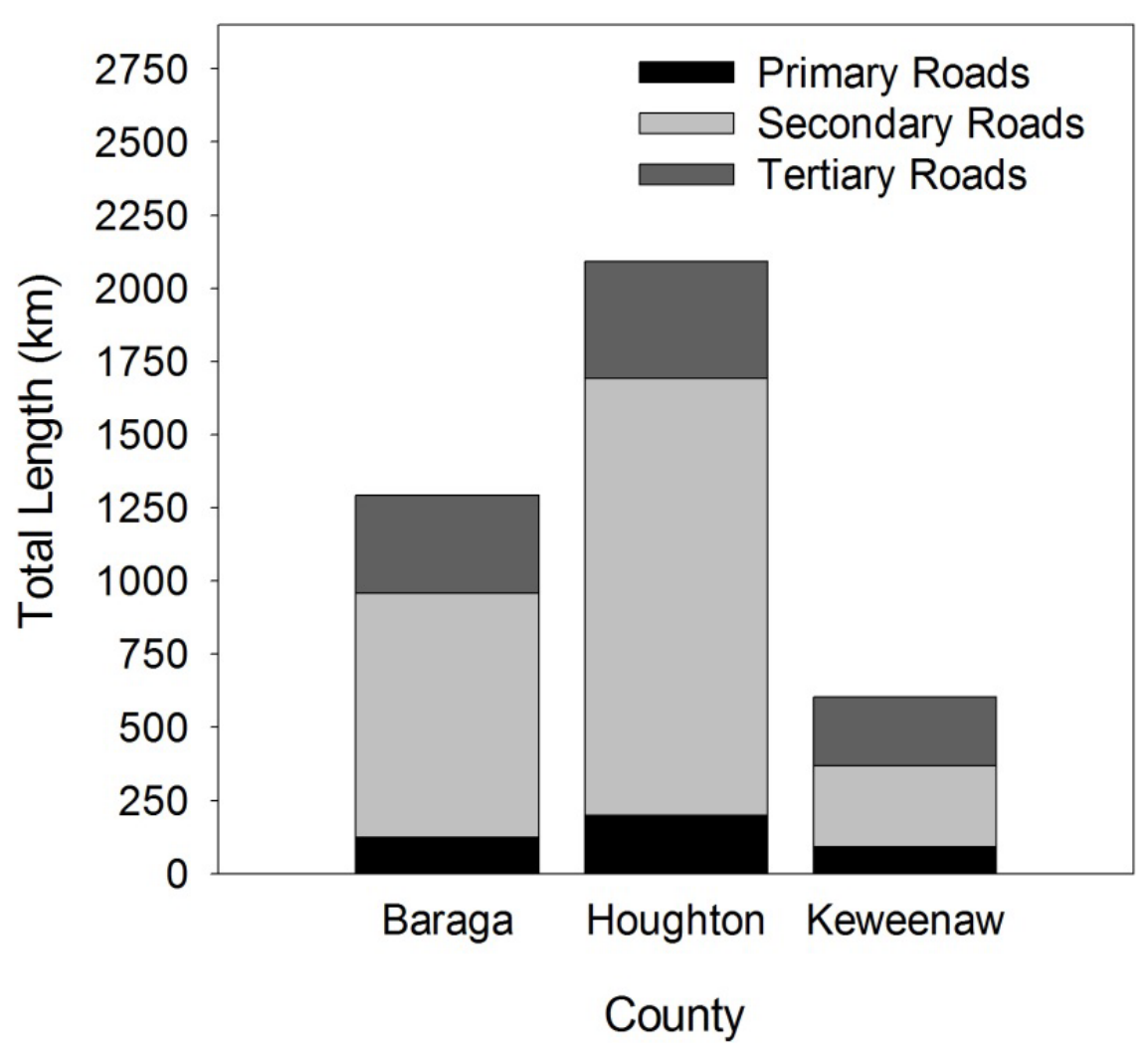

Figure 4.8: Length of primary, secondary, and tertiary roadways in Baraga, Houghton, and Keweenaw Counties of Michigan. 
Table 4.3

Acreage of palustrine wetlands within a 40 meter and $250 \mathrm{~m}$ road-effect zone adjacent to US 41 in Baraga, Houghton, and Keweenaw Counties of Michigan.

\begin{tabular}{lccccccc}
\hline & \multirow{2}{*}{$\begin{array}{c}\text { Area of } \\
\text { palustrine } \\
\text { County }\end{array}$} & & \multicolumn{2}{c}{$\begin{array}{c}\text { US 41 road-effect } \\
\text { zone }\end{array}$} & & \multicolumn{2}{c}{$\begin{array}{c}\text { Palustrine } \\
\text { wetlands }\end{array}$} \\
\cline { 1 - 4 } \cline { 7 - 8 } Baraga & 111,271 & 1,620 & 14,890 & & 154 & 2,152 \\
\hline Houghton & 87,196 & 1,319 & 16,755 & & 117 & 2,210 \\
\hline Keweenaw & 64,439 & 1,185 & 11,515 & & 69 & 1,447 \\
\hline
\end{tabular}

\section{Discussion}

These results suggest a low level of persistent chloride in surface water bodies as a result of moderate road salt use in upper Michigan. The maximum chloride concentrations measured in this study are much lower than from other studies where estimates ranged from 586 (Collins and Russell 2009) to 4,629 (Kaushal et al. 2005) to $18,000 \mathrm{mgL}^{-1}$ (Environment Canada 2001). The conservative salting strategies employed by the transportation management agencies in these three counties appear to be effective in minimizing road salt runoff in nearby surface water bodies. However, even at these low chloride concentrations we have observed significant effects on fitness of larval amphibians (29 $\mathrm{mgL}^{-1}$; Chapter 3). This suggests that amphibians using roadside pools in this area are at a greater risk of negative sublethal effects. Chloride levels were also much lower than the estimated $\mathrm{LC}_{50}$ for $\mathrm{NaCl}$ of $4585 \mathrm{mgL}^{-1}$ (Chapter 2; Harless et al. 2011), suggesting these populations are not at risk of lethal effects from local road salt application.

In considering the conservative road-effect zone estimate $(250 \mathrm{~m})$ from previous studies, this analysis suggests that Houghton County contains the most acreage of wetlands that may be impacted by road salt use. Houghton County also contains the most mileage of primary (state and federal highways) but the least overall acreage of palustrine wetlands 
in these three counties. However, when using a road-effect zone of $40 \mathrm{~m}$ the distribution across the three counties is similar. Management efforts focused on reducing the use of road salt would most benefit wetlands in this county, particularly in portions of the northern and southern edge of the county that run through a dense area of these wetlands. Choosing wetlands to protect within a $40 \mathrm{~m}$ road buffer will allow for the protection of the most at risk surface water bodies in these three counties. Monitoring and protecting these areas should be a priority to ensure the continued health of these beneficial perennial wetlands in the Upper Peninsula.

The temporal variations I observed in chloride levels are similar to previous studies. Peaks in chloride occur after the melting of the winter snowpack and in summer where evaporative demand is high. While this study only examined chloride concentrations during the local amphibian breeding season (May - September), I would expect to see elevated chloride levels in March or April during snowmelt with the potential for negative impacts on the survival of embryonic, larval, and adult amphibians. Monitoring roadside water bodies during winter is also warranted to obtain a greater understanding of temporal variations in chloride in roadside surface water bodies.

This spatial analysis indicates that surface water bodies within $40 \mathrm{~m}$ of highway may contain elevated chloride levels as a result of moderate $\mathrm{NaCl}$ application during the winter months. Forman and Deblinger (2000) suggest that the road effect zone is not a constant distance and varies by the ecological factor in question. Heterogeneity in habitat, topography, and resultant hydrology may play a large role in the transport of road salts into the local environment. Groundwater may be recharging these perennial and permanent wetlands decreasing the overall chloride concentrations. In addition, this area is surrounded by large, freshwater lakes that may be contributing to the dilution of these water bodies. An in-depth analysis of the hydrology in these systems could provide valuable insight into this relationship. 


\section{Acknowledgements}

I would like to thank the following individuals for assistance with the field and laboratory portions of this project: P. Nankervis, E. Gorsalitz, H. List, K. Li, R. Reddy, and R. Datta. Funding for this research was provided by grants from the DeVlieg Foundation, the Ecosystem Science Center at Michigan Technological University, with support from the MTU Global Watershed GK-12 program. This research has also been supported by funding and infrastructure provided by Michigan Technological University.

\section{References}

Boarman WI, Sazaki M. 2006. A highway's road-effect zone for desert tortoises (Gopherus agassizii). Journal of Arid Environments. 65:94-101.

Collins SJ, Russell RW. 2009. Toxicity of road salt to Nova Scotia amphibians. Environmental Pollution 157:320-324.

D'Itri FM. Prologue. In: D'Itri FM, ed. Chemical Deicers and the Environment. 1st ed. Boca Raton (FL): Lewis Publishers. 1992. p. v-x.

Eigenbrod F, Hecnar SJ, Fahrig L. 2009. Quantifying the road-effect zone: threshold effects of a motorway on anuran populations in Ontario, Canada. Ecology and Society. $14: 24$.

Environment Canada. 2001. Priority substances list assessment report: Road-salts. Ministry of Public Works and Government Services, Ottawa, Ontario, Canada.

ESRI. 2011. ArcGIS Desktop: Release 10. Redlands, CA: Environmental Systems Research Institute.

Findlay SEG, Kelly VR. 2011. Emerging indirect and long-term road salt effects on ecosystems. In: Annals of the New York Academy of Sciences - The Year in Ecology and Conservation Biology. 1223:58-68. 
Forman R, Alexander L. 1998. Roads and their major ecological effects. Annual Review of Ecological Systems. 29:207-31.

Forman RTT, Deblinger RD. 2000. The ecological road-effect zone of a Massachusetts (USA) suburban highway. Conservation Biology. 14:36-46.

Forman RTT, Sperling D, Bissonette JA, Clevenger AP, Cutshall CD, Dale VH, Fahrig L, France R, Goldman CR, Heanue K, Jones JA, Swanson FJ, Turrentine T, Winter TC. Road Ecology: Science and Solutions. 4th ed. Washington (DC): Island Press. 2003. 504 p.

Godwin KS, Hafner SD, Buff MF. 2003. Long-term trends in sodium and chloride in the Mohawk River, New York: the effect of fifty years of road-salt application. Environmental Pollution. 124:273-281.

Harless, ML, Huckins CJ, Grant JB, Pypker TG. 2011. Effects of six chemical deicers on larval wood frogs (Rana sylvatica). Environmental Toxicology and Chemistry. 30:16371641.

Jaeger JAG, Bowman J, Brennan J, Fahrig L, Bert D, Bouchard J, Charbonneau N, Frank K, Gruber B, von Toschanowitz KT. 2005. Predicting when animal populations are at risk from roads: an interactive model of road avoidance behavior. Ecological Modeling. 185:329-348.

Karraker NE. 2007. Investigation of the amphibian decline phenomenon: Novel smallscale factors and a large-scale overview. PhD thesis. State University of New York, Syracuse, NY, USA. 
Kaushal SS, Groffman PM, Likens GE, Belt KT, Stack WP, Kelly VR, Band LE, Fisher GT. 2005. Increased salinization of fresh water in the northeastern United States. Proceedings of the National Academy of Sciences USA. 102:13517-13520.

Lundmark A, Olofsson B. 2007. Chloride deposition and distribution in soils along a deiced highway - assessment using different methods of measurment. Water, Air and Soil Pollution. 182:173-185.

Montgomery DC, Peck EA, Vining GG. Introduction to Linear regression analysis. 4th ed. Hoboken(NJ):.John Wiley and Sons, Inc; 2006. 618 p.

National Research Council. 1991. Highway Deicing: Comparing Salt and Calcium Magnesium Acetate. Special Report 235. National Research Council, Washington, DC, USA.

R Development Core Team. 2010. R: A Language and Environment for Statistical Computing, version 2.11.1. R. Foundation for Statistical Computing, Vienna, Austria.

Ramakrishna D, Viraraghavan T. 2005. Environmental impact of chemical deicers- a review. Water, Air and Soil Pollution. 166:49-63.

Reijnen R, Foppen R, Ter Braak C, Thissen J. 1995. The effects of car traffic on breeding bird populations in woodland. 3. Reduction of density in relation to the proximity of main roads. Journal of Applied Ecology. 32:187-202.

Semlitsch RA, Ryan JR, Hamed K, Chatfield M, Drehman B, Pekarek N, Spath M, Watland A. 2007. Salamander abundance along road edges and within abandoned logging roads in Appalachian forests. Conservation Biology. 21:159-167.

Trombulak SC, Frissell AC. 2000. Review of Ecological effects of roads on terrestrial and aquatic communities. Conservation Biology 14:18-30. 
US EPA. 1988. Ambient water quality standards for chloride. Criteria and Standards Division. EPA Publication Number 440588001. Washington(DC). 


\title{
Chapter 5: Avoiding the Use of Specific Conductance to Estimate Chloride Concentrations in Natural Water Bodies
}

\begin{abstract}
The health of a freshwater system is often measured using water chemistry variables such as $\mathrm{pH}$, specific conductance or specific conductance, and salinity. Specific conductance is preferred over specific conductance as it adjusts for the temperature of the water sample. Analysis of these systems often requires quantification of specific ions. These data are often expensive and difficult to obtain. Numerous studies have attempted to use linear regression models to predict chloride ion concentrations from measures of specific conductance in natural water bodies. I investigated this relationship using both a large number of water samples collected from natural surface water bodies in the Upper Peninsula of Michigan as well as sodium chloride $(\mathrm{NaCl})$ additions to filtered lake water. This analysis suggests the relationship between chloride concentration and specific conductance may not be sufficient for predicting chloride ion concentrations. While the regression models were significant, residuals were sufficient to warrant caution regarding the use of this method. In addition, many factors other than chloride concentrations affect specific conductance. Researchers should invest in the use of ion chromatography or a similar analytical method to obtain specific ion concentrations.
\end{abstract}

Key Words: chloride, conductivity, specific conductance, water chemistry, ion chromatography 


\section{Introduction}

Water chemistry variables are often used to determine the health of surface water bodies. Commonly used metrics include $\mathrm{pH}$, conductivity or specific conductance, salinity, and determination of ionic concentrations. Conductivity is widely employed as an estimate of the amount of disturbance in a freshwater system. It is defined as a measure of the ability of an aqueous solution to carry an electrical current. Conductivity tends to range widely depending on water temperature. Hence, many researchers prefer to use specific conductance in its place as it represents Conductivity normalized to a temperature of 25 ${ }^{\circ} \mathrm{C}$. Specific conductance may be influenced by the presence of specific ions or the concentration, mobility, and valence of these ions (Eaton et al. 2005). These influential ions may include anions (e.g., chloride, nitrate, sulfate, and phosphate) or cations (e.g., sodium, magnesium, calcium, iron, and aluminum). In general, solutions with a high concentration of ions have high specific conductance. Specific conductance is calculated by taking the reciprocal of the electrical resistance. Portable water meters measure this by passing current between two spatially fixed and chemically inert electrodes (Eaton et al. 2005).

Hamilton (1978) developed a procedure for determining the specific conductance of naturally occurring waters. Using known concentrations of the major ions $\left(\mathrm{Ca}^{2+}, \mathrm{Mg}^{2+}\right.$, $\mathrm{Na}^{+}, \mathrm{K}^{+}, \mathrm{HCO}_{3}, \mathrm{SO}_{4}{ }^{2}$, and $\left.\mathrm{Cl}^{-}\right)$, specific conductance can be calculated using the conductances of these ions in water with total dissolved solids (TDS) less than $2500 \mathrm{mgL}$

${ }^{1}$. Here the contribution of each ion is calculated by multiplying equivalent conductances by the ionic strength resulting in the infinite dilution specific conductance value. Using these values of ionic concentration, the specific conductance was estimated at 47.88 $\mathrm{mS} / \mathrm{m}$. This method retained an error of less than $2 \%$ when used on an analysis of 39 natural water bodies (reviewed in Hamilton 1978). Because this method requires a number of known values, the reverse calculation of ionic concentrations from specific conductance is not warranted.

Chloride concentrations are often measured to evaluate the health of natural water bodies. Chloride $\left(\mathrm{Cl}^{-}\right)$, may originate from a number of natural and anthropogenic sources. 
Sodium chloride $(\mathrm{NaCl})$ is widely used as a food additive and passes through the digestive system unchanged. In addition, sodium chloride and other inorganic salts may leach into freshwater systems near oceans hereby elevating the concentration of $\mathrm{Cl}^{-}$. Industrial and transportation agencies may also cause an increase in $\mathrm{Cl}^{-}$concentration through the use of $\mathrm{NaCl}$ in manufacturing and winter maintenance activities (reviewed in Eaton et al. 2005).

While chloride ion concentration estimates are included in Hamilton's algorithm, the concentration of this ion in natural water bodies is not likely to be directly correlated to specific conductance values. The preferred method of determining the concentration of $\mathrm{Cl}^{-}$in natural water bodies is through the use of ion chromatography. Other methods include the argentometric method, the mercuric nitrate method, the potentiometric method, the automated ferricyanide method, mercuric thiocyanate flow injection analysis, or the capillary ion electrophoresis method (Eaton et al. 2005). Ion chromatography is preferred over many of these methods because it does not require the use of hazardous reagents such as mercury.

For field based studies, the use of ion chromatography presents a logistical challenge. Water samples are sensitive to time and temperature. Ion chromatography methods are not appropriate for long-term monitoring as it requires a significant amount of time to obtain results. In addition, it may be quite expensive to purchase an ion chromatography system or send a large number of samples to a laboratory for analytical ionic analysis.

A number of studies have used evidence of a significant regression fit between specific conductance and chloride concentration in their field samples to estimate $\mathrm{Cl}^{-}$ concentration from other water samples within their study. For example, Zinabu et al. (2002) examined the use of specific conductance as a predictor of both cation concentration and salinity in rivers and lakes in Ethiopia. They determined a significant linear relationship between specific conductance with both total cation concentration and salinity. Curiously, these relationships were not significantly different when comparing values from saline versus freshwater bodies. Paine (2003) used specific conductance to 
estimate chloride in Texas water bodies where a significant relationship between chloride, conductivity, and total dissolved solids was demonstrated in this system. Similarly, El-Korashey et al. (2009) identified the use of regression analysis to successfully estimate $\mathrm{Cl}^{-}$concentration from specific conductance values in a specific drainage system. Brand et al. (2010) used ion chromatography to determine $\mathrm{Cl}^{-}$ concentration in experimental bins then used the regression between chloride and specific conductance in these samples to estimate $\mathrm{Cl}^{-}$concentration in other experimental samples.

Authors have also used the relationship between conductivity and chloride concentration in natural surface waters to determine sodium chloride $(\mathrm{NaCl})$ tolerance. Karraker $(2007 \mathrm{a}, \mathrm{b})$ investigated the sensitivity of two larval amphibians to $\mathrm{Cl}^{-}$exposure through manipulating the conductivity of test solutions by the addition of $\mathrm{NaCl}$. The test solutions were made using laboratory grade water with the appropriate amount of $\mathrm{NaCl}$ added to obtain the four test conductivity levels. $\mathrm{Cl}^{-}$concentration at each conductivity level was determined using Inductively Coupled Plasma - Optical Emission Spectrometry (Karraker 2007b). No information was given as to the relationship between these variables used in this experiment.

While these authors warned against the use of their regression values in systems outside of their study area, the use of this regression raises questions about the validity of the $\mathrm{Cl}^{-}$ estimates derived from this type of analysis. The purpose of this note is to examine the use of regression models to accurately predict chloride concentration from specific conductance in natural water bodies.

\section{Methods}

I evaluated this method on water samples collected as a part of a larger study on the impacts of winter de-icing activities on surface water quality in Michigan's Upper Peninsula. I collected field measurements of specific conductance using a YSI 63 probe (Yellow Springs International, Yellow Springs, $\mathrm{OH}$ ) that was calibrated daily. I collected water samples from 105 wetlands and vernal pools across Baraga, Houghton, and 
Keweenaw Counties from May through September in 2009. Water samples were returned to the laboratory and stored at $4 \square \mathrm{C}$. I filtered the samples through a $0.45 \mu \mathrm{m}$ cellulose acetate filter and quantified chloride concentration using ion chromatography (Dionex ICS-900, AS22 4 mm column, Fisher Scientific Inc., Sunnyvale CA). To determine the relationship between sodium chloride $(\mathrm{NaCl})$ additions to specific conductance in natural surface waters, I mixed known concentrations of $\mathrm{NaCl}(0,190,320,540,900,1500$, 2400 , and $3800 \mathrm{mgL}^{-1}$ ) into $2 \mathrm{~L}$ of filtered water from Portage Lake, Michigan. I allowed the $\mathrm{NaCl}$ to dissolve and took measurements of specific conductance using a YSI 63 probe. I repeated this procedure using deionized water to determine the relationship between specific conductance and $\mathrm{NaCl}$ concentration in laboratory water samples. I developed a simple linear regression model from specific conductance values to predict either chloride or $\mathrm{NaCl}$ concentrations. I used "R: A Language and Environment for Statistical Computing" to perform all statistical analyses with an alpha level of 0.05 (R Development Core Team 2010).

\section{Results and Discussion}

Chloride concentrations in local perennial wetlands ranged from 0.0 to $18.3 \mathrm{mgL}^{-1}$ (mean $=1.84)$. A significant linear relationship between specific conductance and chloride in these samples was detected (Adj. $\mathrm{R}^{2}=0.391, \mathrm{~F}_{1,228}=148.2, \mathrm{P}<0.001$; parameter estimates: slope 0.015 , intercept -0.783 ; Figure 5.1 ). While the correlation between specific conductance and chloride values measured in this study fit a general linear model, examination of the residuals suggest that chloride estimates derived from specific conductance values are wide ranging. Some highly diverged $\mathrm{Cl}^{-}$was detected at specific conductance levels below $300 \mu \mathrm{S}$, encompassing $88 \%$ of samples in this study. These chloride estimates using this formula on natural water samples were on average $9.4(0.18$ 18.3) $\mathrm{mgL}^{-1}$ from the fitted model. Similarly, the linear model underestimate $\mathrm{NaCl}$ concentrations in samples using Portage Lake water (Adj. $\mathrm{R}^{2}=0.981, \mathrm{~F}_{1,31}=1642.56, \mathrm{P}$ $<0.001$; parameter estimates: slope 0.72 , intercept -272.72 ) as evidenced by the regression intercept and analysis of the residuals (Figure 5.2). In deionized water, the model tended to overestimate $\mathrm{NaCl}$ concentration (Adj. $\mathrm{R}^{2}=0.993, \mathrm{~F}_{1,31}=4657.76, \mathrm{P}<$ 
0.001; parameter estimates: slope 0.58, intercept -42.08 ; Figure 5.3) yet provided a better fit to $\mathrm{NaCl}$ concentration than in the model using natural water samples.

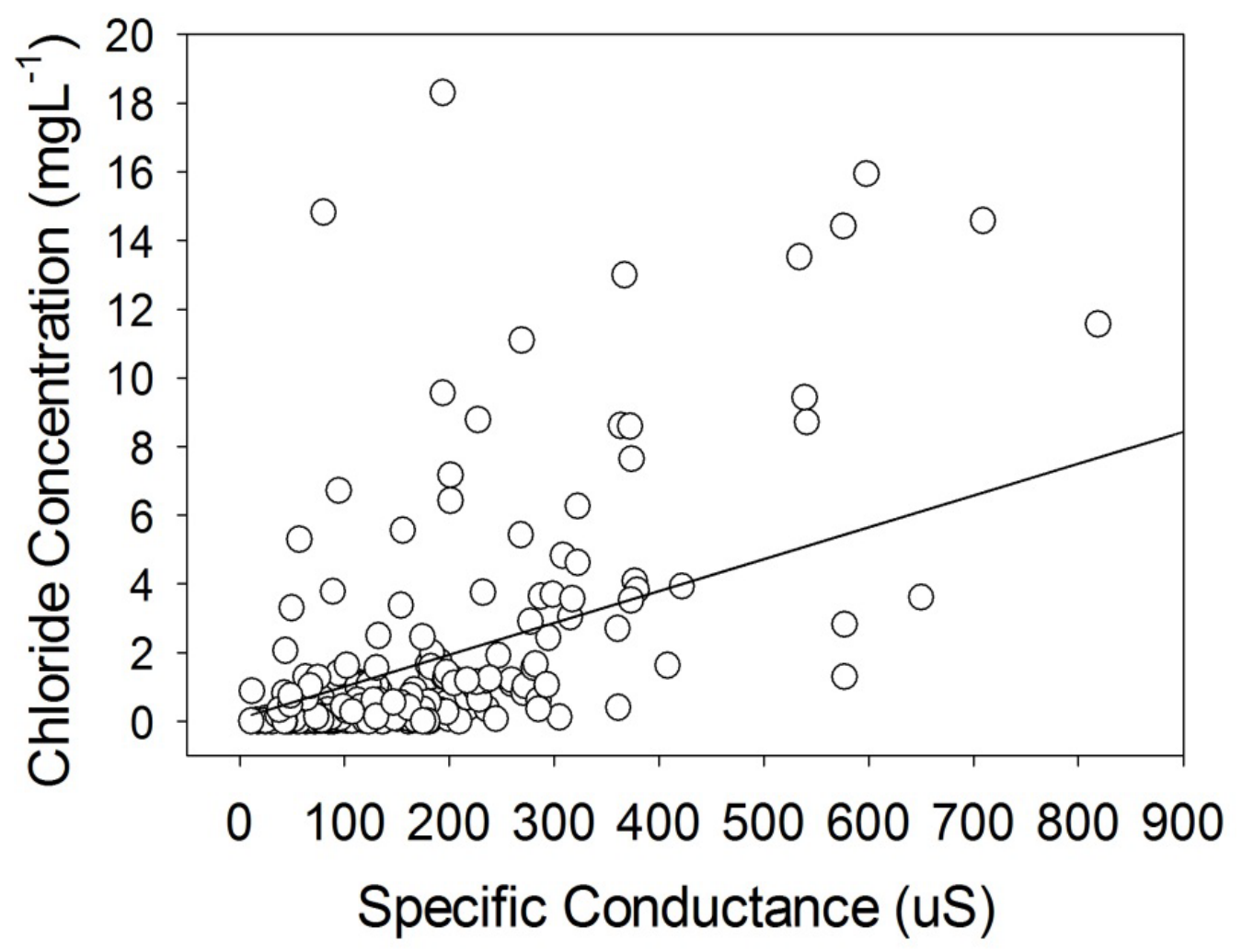

Figure 5.1: The relationship between chloride and specific conductance in natural water samples $(\mathrm{N}=230)$. The fit line represents a linear regression model $(\mathrm{y}=0.015 \mathrm{x}-0.783$; Adj. $\left.R^{2}=0.391\right)$. 


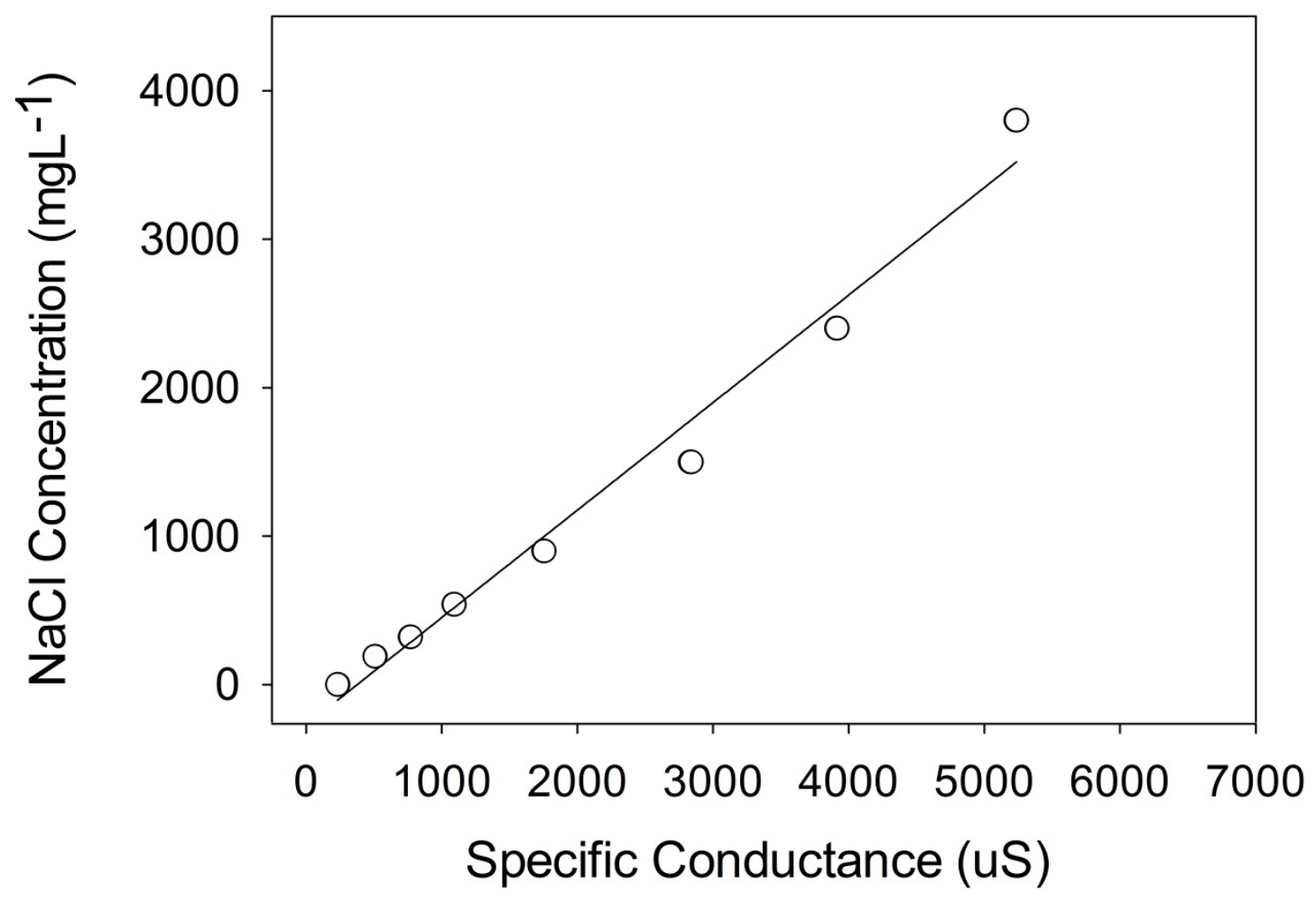

Figure 5.2: The relationship between specific conductance and sodium chloride $(\mathrm{NaCl})$ additions in natural water samples from Portage Lake, Michigan $(\mathrm{N}=32)$. The fit line represents a linear regression model $\left(y=0.72 x-272.72 ; A d j . R^{2}=0.981\right)$. 


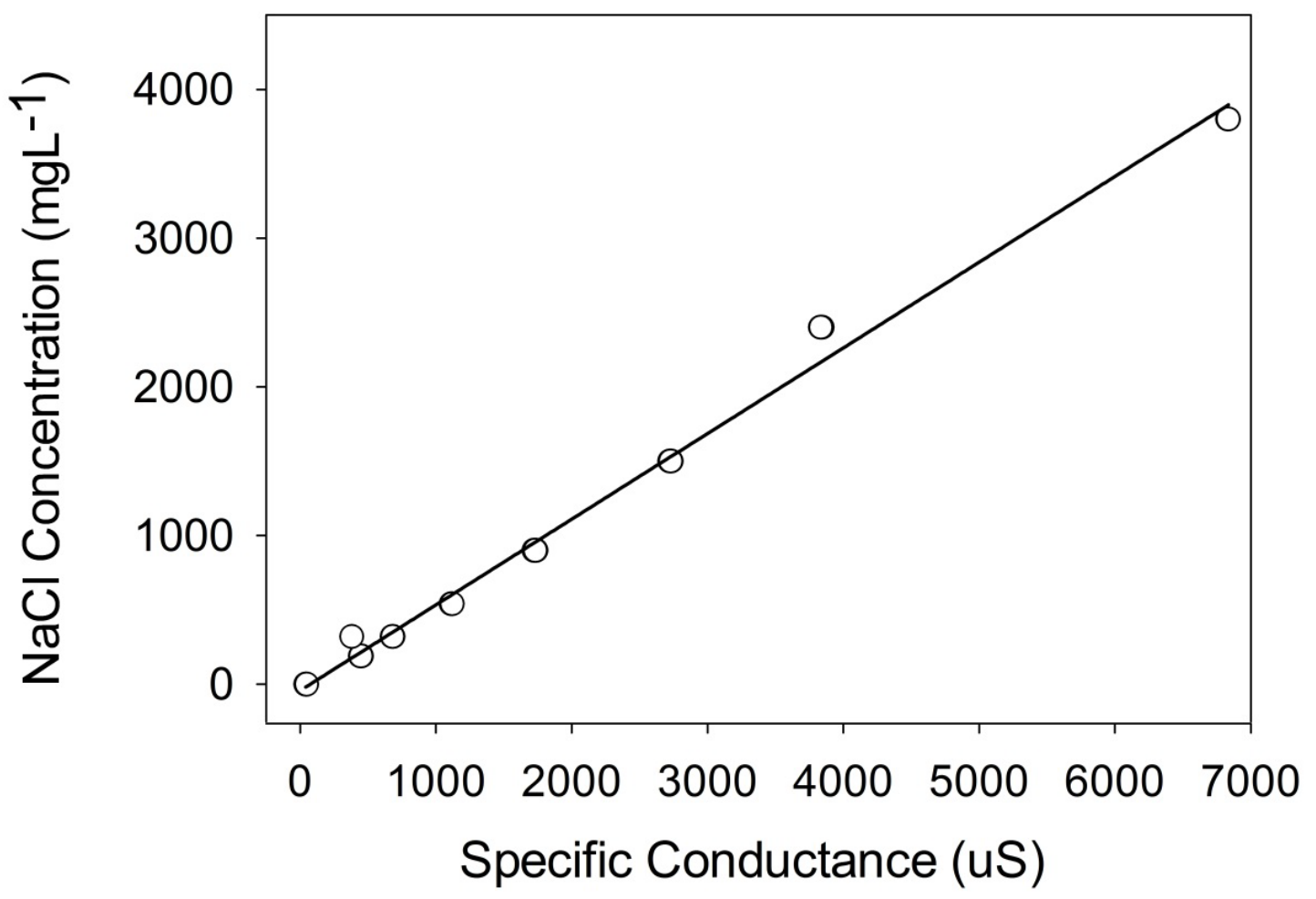

Figure 5.2: The relationship between specific conductance and sodium chloride $(\mathrm{NaCl})$ additions in deionized water $(\mathrm{N}=32)$. The fit line represents a linear regression model $(\mathrm{y}$ $=0.58 \mathrm{x}-42.08 ;$ Adj. $\left.\mathrm{R}^{2}=0.993\right)$. 
It is likely that the presence of ions in addition to $\mathrm{Cl}^{-}$in surface water bodies contributed to the variance in predicted chloride concentration. Hence, it is not recommended to use a simple model like this for estimation of a single ion in natural water bodies without knowledge of the concentration of additional ions (e.g., Hamilton 1978). In addition, we caution against the use of these regression equations between water sources as $\mathrm{Cl}^{-}$ estimates are likely to vary widely when calculated from specific conductance. While this method may be cheap and relatively quick, its use will not take the place of analytical methods such as ion chromatography.

In addition, the use of a linear model derived from one water system should not be used to predict ion concentrations in different water systems. Ion concentrations in freshwater systems may vary greatly in both space and time, making comparisons between analyses using separate water samples difficult. This variance is particularly true for chloride, as it is affected by land use activities (Findlay and Kelly 2011) suggesting caution is advised when attributing an increase in specific conductance to a singular ion.

\section{References}

Brand AB, Snodgrass JW, Gallagher MT, Casey RE, Van Meter R. 2009. Lethal and sublethal effects of embryonic and larval exposure of Hyla versicolor to Stormwater pond sediments. Environmental Contamination and Toxicology. 58:325-331.

Eaton AD, Clesceri LS, Rice EW, Greenberg AE, Franson MAH. 2005. Standard methods for the examination of water and wastewater: Centennial edition. Washington DC: American Public Health Association. 1368 p.

El-Korashey R. 2009. Using regression analysis to estimate water quality constituents in Bahr El Baqar Drain. Journal of Applied Sciences Research 5:1067-1076.

Findlay SEG, Kelly VR. 2011. Emerging indirect and long-term road salt effects on ecosystems. Annals of the New York Academy of Sciences. 
Hamilton CE. 1978. Manual on Water. ASTM Spec. Tech. Publ. 442A, 4th ed. American Soc. Testing \& Materials, Philadelphia, Pa.

Karraker NE. 2007a. Are embryonic and larval green frogs (Rana clamitans) insensitive to road deicing salt? Herpetological Conservation and Biology. 2:35-41.

Karraker NE. 2007b. Investigation of the amphibian decline phenomenon: Novel smallscale factors and a large-scale overview. Ph.D. dissertation, State University of New York, College of Environmental Science and Forestry, Syracuse, New York.

Miller RL, Bradford WL, Peters NE. 1988. Specific conductance-Theoretical considerations and application to analytical quality control: U.S. Geological Survey Water-Supply Paper 2311. 16 p.

Paine JG. 2003. Determining salinization extent, identifying salinity sources, and estimating chloride mass using surface, borehole, and airborne electromagnetic induction methods. Water Resources Research. 39:1-10.

Tchobanoglous G, Schroeder ED. 1985. Water Quality, Vol.1. Reading (MA): AddisonWesley Publishing Company. 768 p.

Zinabu GM, Chapman LJ, Chapman, CA. 2002. Specific conductance as a predictor of total cations and salinity in Ethiopian lakes and rivers: revisiting earlier models. Limnologica. 32:21-26. 


\section{Conclusions}

The overall goal of this research project was to better understand the impacts of chemical deicers on freshwater ecosystems through a mixture of laboratory studies with larval amphibians and water chemistry analyses. The widespread use of these chemicals to remove or prevent ice from bonding to pavements surfaces represents a significant source of contamination from roads and highways. Freshwater organisms using waters receiving this runoff may be exposed to salts and other chemical beyond their tolerance level. This research adds to the body of literature regarding the environmental impacts of chemical deicers in that it provides greater detail as to the population level response of larval amphibians and the environmental contamination resulting from $\mathrm{NaCl}$ application.

Through a series of acute toxicity tests, I determined that not all chemical deicers are created equally. Larval wood frogs (Lithobates sylvatica) were least sensitive to urea $\left(\mathrm{CH}_{4} \mathrm{~N}_{2} \mathrm{O}\right)$, road salt $(\mathrm{NaCl})$, and magnesium chloride $\left(\mathrm{MgCl}_{2}\right)$. However, these larvae were very sensitive when exposed to acetate products $\left(\mathrm{C}_{8} \mathrm{H}_{12} \mathrm{CaMgO}_{8}, \mathrm{CH}_{3} \mathrm{COOK}\right)$ and calcium chloride $\left(\mathrm{CaCl}_{2}\right)$. The differences in the response of these sensitive organisms suggests that switching to the use of alternative products (e.g., acetates) to avoid chloride contamination of drinking water source may cause greater harm to freshwater ecosystems than previously thought. In addition, the higher tolerance of this population of $L$. sylvatica to high $\mathrm{NaCl}$ levels that those in previous studies suggests that population level differences and/or local adaptation of $\mathrm{NaCl}$ exposure need further examination.

In Chapter 3, I demonstrated that amphibians employing different life history strategies respond differently to long-term exposure to $\mathrm{NaCl}$ during development. Both L. sylvatica and green frogs (L. clamitans) demonstrated potentially harmful effects of $\mathrm{NaCl}$ exposure on individual fitness. The high occurrence of edema in L. sylvatica suggests this exposure represents a significant physiological stressor to these rapidly developing larvae. In addition, $L$. clamitans demonstrated a reduction in tail size when exposed to higher levels of $\mathrm{NaCl}$ which may decrease adult fitness of these individuals. The phenotypic plasticity 
of $L$. clamitans larvae may play a part in this observation and would be worthwhile to examine in more detail.

Analysis of the spatial distribution of chloride in the three northernmost counties of Michigan suggests that amphibians may encounter harmful levels of chloride when using water bodies in this area. The relatively low rates of $\mathrm{NaCl}$ application in this region compared to urban areas are reflected in the lowest maximum chloride levels observed in this study. However, these levels are not beyond those in which significant sublethal impacts have been observed. While the road effect zone of $\mathrm{NaCl}$ exposure in this area may be large ( $40 \mathrm{~m})$, the temporal variability in chloride concentrations throughout the amphibian breeding season (e.g., variable hydroperiods) may cause water bodies far from salt-treated roads to experience harmful levels of chloride.

Finally, an in depth analysis of the use of specific conductance to predict chloride concentrations in surface water bodies suggests that this correlation is too variable to accurately predict specific ion content. Researchers interested in this measurement should seek alternative methods of analytical analysis. 


\section{References}

American Society for Testing and Materials. Standard guide for conducting acute toxicity tests on test materials with fishes, macroinvertebrates, and amphibians. ASTM E729-96. In: ASTM. Annual Book of ASTM Standards, Volume 11.06. 2006. Philadelphia (PA). p 79-100.

Bang SS, Johnston D. 1998. Environment effects of sodium acetate/formate deicer, Ice Shear $^{\mathrm{TM}}$. Archives of Environmental Contamination and Toxicology. 35:580-587.

Boarman WI, Sazaki M. 2006. A highway's road-effect zone for desert tortoises (Gopherus agassizii). Journal of Arid Environments. 65:94-101.

Benbow ME, Merritt RW. 2004. Road-salt toxicity of select Michigan wetland macroinvertebrates under different testing conditions. Wetlands. 24:68-76.

Blasius BJ, Merrit RW. 2002. Field and laboratory investigations on the effects of road salt $(\mathrm{NaCl})$ on stream macroinvertebrate communities. Environmental Pollution. 120:21931.

Blomqvist G. 1999. Air-borne transport of de-icing salt and damage to pine and spruce trees in a roadside environment. Division of Land and Water Resources, Department of Civil and Environmental Engineering, Royal Institute of Technology, Stockholm.

Bogemans J, Nierinck L, Stassart JM. 1989. Effect of deicing chloride salts on ion accumulation in spruce (Picea abies (L.) sp.). Plant and Soil. 113:3-11.

Bollinger TK, Mineau O, Wickstrom ML. 2005. Toxicity of Sodium Chloride to House Sparrows (Passer domesticus). Journal of Wildlife Diseases. 41:363-370. 
Brand AB, Snodgrass JW, Gallagher MT, Casey RE, Van Meter R. 2009. Lethal and sublethal effects of embryonic and larval exposure of Hyla versicolor to Stormwater pond sediments. Environmental Contamination and Toxicology. 58:325-331.

Bridgeman TB, Wallace CD, Carter GS, Carvajal R, Schiesari LC, Aslam S, Cloyd E, Elder E, Field A, Schulz KL, Yurista PM, Kling GW. 2000. A limnological survey of Third Sister Lake, Michigan with historical comparisons. Journal of Lake and Reservoir Management. 16:253-267.

Bryson GM, Barker AV. 2002. Sodium accumulation in soils and plants along Massachusetts Roadsides. Community Soil Science Plant Annuals. 33:67-78.

Burtwell M. 2001. Assessment of the performance of pre-wetted salt for snow removal and ice control. Transportation Research Record 1741, Paper No. S00-0052. Berkshire, United Kingdom.

Calabrese EJ, Tuthill RW. 1979. Elevated sodium levels in the public drinking water as a contributor to elevated blood pressure levels in the community. Archives of Environmental Health. 34:197-203.

Creighton TE. 1991. Molecular chaperones: unfolding protein folding. Nature. 352:1718.

Collins SJ, Russell RW. 2009. Toxicity of road salt to Nova Scotia amphibians. Environmental Pollution. 157:320-324.

Conant R, Collins JT. 1998. A Field Guide to Reptiles and Amphibians: Eastern and Central North America. 3rd ed. Boston (MA): Houghton Mifflin Company. 450 p.

Costanzo JP, Lee RE, Ultsch GR. 2008. Physiological ecology of overwintering in hatchling turtles. Journal of Experimental Zoology. 309A: 297-379. 
D'Itri FM. Prologue. In: D'Itri FM, ed. Chemical Deicers and the Environment. 1st ed. Boca Raton (FL): Lewis Publishers. 1992. p. v-x.

Demers C, Sage R. 1990. Effects of road deicing salts on chloride levels in four Adirondack. streams. Water, Air and Soil Pollution. 49: 369-373.

Dougherty CK, Smith GR. 2006. Acute effects of road de-icers on the tadpoles of three anurans. Applied Herpetology 3: 87-93.

Eaton AD, Clesceri LS, Rice EW, Greenberg AE, Franson MAH. 2005. Standard methods for the examination of water and wastewater: Centennial edition. Washington DC: American Public Health Association. 1368 p.

Eigenbrod F, Hecnar SJ, Fahrig L. 2009. Quantifying the road-effect zone: threshold effects of a motorway on anuran populations in Ontario, Canada. Ecology and Society. $14: 24$.

El-Korashey R. 2009. Using regression analysis to estimate water quality constituents in Bahr El Baqar Drain. Journal of Applied Sciences Research 5:1067-1076.

Environment Canada. 2001. Priority Substances List Assessment Report for Road Salts. Environment Canada, Catalog number En40-215/63E. Ottawa, Ontario, Canada.

ESRI. 2011. ArcGIS Desktop: Release 10. Redlands, CA: Environmental Systems Research Institute.

Findlay SEG, Kelly VR. 2011. Emerging indirect and long-term road salt effects on ecosystems. Annals of the New York Academy of Sciences. 1223:58-68. 
Forman RTT. 2004. Road ecology's promise: What's around the bend? Environment. 46:8-21.

Forman R, Alexander L. 1998. Roads and their major ecological effects. Annual Review of Ecological Systems. 29:207-31.

Forman RTT, Reineking B, Hersperger AM. 2002. Road traffic and nearby grassland bird patterns in a suburbanizing landscape. Environmental Management. 29: 782-800.

Forman RTT, Sperling D, Bissonette JA, Clevenger AP, Cutshall CD, Dale VH, Fahrig L, France R, Goldman CR, Heanue K, Jones JA, Swanson FJ, Turrentine T, Winter TC. 2003. Road Ecology Science and Solutions. 1st ed. Washington (DC): Island Press. 504 p.

Fostad O, Pedersen PA. 2000. Container-grown tree seedling responses to sodium chloride application in different substrates. Environmental Pollution. 109:203-210.

Fraser D, Thomas ER. 1982. Moose-vehicle accidents in Ontario: relation to highway salt. Wildlife Society Bulletin. 10:261-265.

Freda J. 1991. The effects of aluminum and other metals on amphibians. Environmental Pollution. 71:305-328.

Fritzsche CJ. 1992. Calcium magnesium acetate deicer. Water Environment and Technology. 4: 44-51.

Gales JE, VanderMeulen J. 1992. Deicing Chemical Use in the State of Michigan. In D'Itri FM, ed, Chemical Deicers and the Environment. 1st ed. Boca Raton (FL): Lewis Publishing..p. 135-184. 
Gionfriddo JP, Best LB. 1995. Grit use by house sparrows: Effects of diet and grit size. Condor. 97: 57-67.

Godwin KS, Hafner SD, Buff MF. 2003. Long-term trends in sodium and chloride in the Mohawk River, New York: the effect of fifty years of road-salt application.

Environmental Pollution. 124:273-281.

Goldman CR, Lubnow FS, Elser JJ. Environmental effects of calcium magnesium acetate on natural phytoplankton and bacterial communities in northern California lakes. In: D'Itri FM, ed. Chemical Deicers and the Environment. 1st ed. Boca Raton (FL): Lewis Publishers. 1992. p. 229-244.

Gomez-Mestre I, Tejedo M, Ramayo E, Estepa J. 2004. Developmental alterations and osmoregulatory physiology of a larval anuran under osmotic stress. Physiological and Biochemical Zoology. 77:267-274.

Gosner KL. 1960. A simple table for staging anuran embryos and larvae with notes on identification. Herpetologica. 16:183-190.

Gosner KL, Black IH. 1957. The effects of acidity on the development and hatching of New Jersey frogs. Ecology. 38:256-262.

Gutiw PL.1998. Roadside salinity changes by pavement deicer application on a Saskatchewan highway. PhD thesis. University of Regina, Regina, Saskatchewan, Canada.

Hamilton CE. 1978. Manual on Water. ASTM Spec. Tech. Publ. 442A, 4th ed. American Soc. Testing \& Materials, Philadelphia, Pa. 
Hamilton MA, Russo RC, Thurston RV. 1977. Trimmed Spearman-Karber method for measuring median lethal concentrations in toxicity bioassays. Environmental Science and Technology. 11:714-719.

Harless ML, Huckins CJ, Grant JB, Pypker TG. 2011. Effects of six chemical deicers on larval wood frogs (Rana sylvatica). Environmental Toxicology and Chemistry. 30:16371641.

Harris GP, Turner R, Nelson RJ. 1993. Field test comparison of calcium magnesium acetate to salt. Journal of Transportation Engineering. 119:889-905.

Hassan Y, Abd El Halim AO, Razaqpur AG, Bekheet W, Farha MH.2002. Effects of runway deicers on pavement materials and mixes: comparison with road salt. Journal of Transportation Engineering. 128 :385-391.

Hofmann E, Ford S, Powell E, Klinck J. 2000. Modeling studies of the effect of climate variability on MSX disease in eastern oyster (Crassostrea virginica) populations. Hydrobiologia. 460:195-212.

Hoffman RS, Capel PD, Larson SJ. 2000. Comparison of pesticides in eight U.S. urban streams. Environmental Toxicology and Chemistry. 19:2249-2258.

Hootman RG, Kelsey PD. 1992. Woody Plants and Roadway Salt: An Urban Dilemma.The Morton Arboretum Quarterly 28:44-48.

Horner RR. 1988. Environmental monitoring and evaluation of calcium magnesium acetate (CMA). NCHRP-305. TRB, National Research Council, Washington DC, USA.

Howard RJ, Mendelssohn IA. 1999. Salinity as a constraint on growth of oligohaline marsh macrophytes. I. Species variation in stress tolerance. American Journal of Botany. 86:785-794. 
Howard WF, Maier H. 2006. Road De-Icing Salt as a Potential Constraint on Urban Growth in the Greater Toronto Area, Canada. Journal of Contaminant Hydrology. 91:146-170.

Howe GE, Gillis R, Mowbray RC. 1998. Effect of chemical synergy and larval stage on the toxicity of atrazine and alachlor to amphibian larvae. Environmental Toxicology and Chemistry. 17:519-525.

Isabelle PS, Fooks LJ, Keddy PA, Wilson SD. 1987. Effects of roadside snowmelt on wetland vegetation: An experimental study. Journal of Environmental Management. 25:57-60.

Jaeger JAG, Bowman J, Brennan J, Fahrig L, Bert D, Bouchard J, Charbonneau N, Frank K, Gruber B, von Toschanowitz KT. 2005. Predicting when animal populations are at risk from roads: an interactive model of road avoidance behavior. Ecological Modeling. 185:329-348.

Jones PH, Jeffery BA, Walter PK, Hutchon H. Environmental Impact of Road Salting. In: D'Itri FM, ed. Chemical Deicers and the Environment. 1st ed. Boca Raton (FL): Lewis Publishers. 1992. p. 1-116.

Judd J. 1970. Lake stratification caused by runoff from street deicing. University of Wisconsin- Milwaukee, Center for Great Lakes Studies. 4:521-532.

Judd JH, Stegall JW. 1982. Reevaluation of the effects of deicing salt runoff on a small lake. National Technical Information Service, Springfield, Virginia.

Karraker NE. 2007a. Are embryonic and larval green frogs (Rana clamitans) insensitive to road deicing salt? Herpetological Conservation and Biology. 2:35-41. 
Karraker NE. 2007b. Investigation of the amphibian decline phenomenon: Novel smallscale factors and a large-scale overview. Ph.D. dissertation, State University of New York, College of Environmental Science and Forestry, Syracuse, New York.

Karraker NE, Gibbs JP, Vonesh JR. 2008. Impacts of road de-icing salt on the demography of vernal pool-breeding amphibians. Ecological Applications. 18:724-734.

Karraker NE, Ruthig GR. 2009. Effect of road deicing salt on the susceptibility of amphibian embryos to infection by water molds. Environmental Research. 109:40-45.

Kaushal SS, Groffman PM, Likens GE, Belt KT, Stack WP, Kelly VR, Band LE, Fisher GT. 2005. Increased salinization of fresh water in the northeastern United States. Proceedings of the National Academy of Sciences USA. 102:13517-13520.

Kincaid DW, Findlay SEG. 2009. Sources of elevated chloride in local streams: Groundwater and soils as potential reservoirs. Water, Air, and Soil Pollution. 203:335342.

Latham PJ, Pearlstine LG, Kitchens WM. 1991. Spatial distributions of the softstem bulrush, Scirpus robustus validus, across a salinity gradient. Estuaries. 14:192198.

Leblond M, Dussault C, Ouellet JP, Poulin M, Courtois R, Fortin J. 2007. Management of roadside salt pools to reduce moose-vehicle collisions. Journal of Wildlife Management. 71:2304-2310.

Lundmark A, Olofsson B. 2007. Chloride deposition and distribution in soils along a deiced highway - assessment using different methods of measurment. Water, Air and Soil Pollution. 182:173-185. 
Marco A, Cash D, Belden LK, Blaustein AR. 2001. Sensitivity to urea fertilization in three amphibian species. Archives of Environmental Contamination and Toxicology. 40:406-409.

McFarland BL, O’ Reilly KT. 1992. Environmental impact and toxicological characteristics of calcium magnesium acetate. In: D'Itri FM, ed. Chemical Deicers and the Environment. 1st ed. Boca Raton (FL): Lewis Publishers. 1992. p. 194-227.

McKee KL, Mendelssohn IA. 1989.Response of a freshwater marsh plant community to increased salinity and increased water level. Aquatic Botany. 34:301-316.

Meister R, Van Den Brink PJ. The Analysis of Laboratory Toxicity Experiments. In Sparks T, ed, Statistics in Ecotoxicology, 1st ed. 2000. Chichester (England): Wiley Publishing. p 100-118.

Miklovic LG, Galatowitsch SM. 2005. Effects of $\mathrm{NaCl}$ and Typha angustifolia on marsh community establishment: a greenhouse study. Wetlands. 25: 420-429.

Miller RL, Bradford WL, Peters NE. 1988. Specific conductance-Theoretical considerations and application to analytical quality control: U.S. Geological Survey Water-Supply Paper 2311. 16 p.

Mineau P, Brownlee L. 2005. Road salts and wildlife - An assessment of the risk with particular emphasis on winter finch mortality. Wildlife Society Bulletin. 33: 835-841.

Montgomery DC, Peck EA, Vining GG. Introduction to Linear regression analysis. 4th ed. Hoboken(NJ):.John Wiley and Sons, Inc; 2006. 618 p.

Molles MC. Effects of Road Salting on Stream Invertebrate Communities, USDA Forest Service, Eisenhower Consortium Bulletin, 1980. 
National Oceanic and Atmospheric Administration (NOAA) [Internet]. 2012. National Climate Data Center. Average Snowfall Record for Marquette, Michigan from 19462011; [updated 2008 Aug 20, cited 2012 Jan 8]. Available from: http://lwf.ncdc.noaa.gov/oa/climate/online/ccd/snowfall.html

National Research Council, Transportation Research Board. 1991. Highway Deicing: Comparing Salt and Calcium Magnesium Acetate. Special Report 235. www.nas.edu/trb/publications/sr235.html.

Newcombe CP, MacDonald DD. 1991. Effects of suspended sediments on aquatic ecosystems. North American Journal of Fisheries Management. 11: 72-82.

Oberts GL. 1986. Pollutants associated with sand and salt applied to roads in Minnesota. Water Resources Bulletin. 22:479-483.

Oehlmann J, Schulte-Oehlmann U, Kloas W, Jagnytsch O, Lutz I, Kusk KO, Wollenberger L, Santos EM, Paul GC, Van Look KJW, Tyler CR. 2009. A critical analysis of the biological impacts of plasticizers on wildlife. Philosophy Transactions of the Royal Society B: Biological Sciences. 364:2047-2062.

Paine JG. 2003. Determining salinization extent, identifying salinity sources, and estimating chloride mass using surface, borehole, and airborne electromagnetic induction methods. Water Resources Research. 39:1-10.

Panno SV, Nuzzo VA, Cartwright K, Hensel BR, Krapac IG. 1999. Impact of urban development on the chemical composition of groundwater in a fen-wetland complex. Wetlands. 19:1.

Paschka MG, Ghosh RS, Dzombak DA. 1999. Potential water-quality effects from iron cyanide anticaking agents in road salt. Water Environment Research. 6:12351239. 
Pauley TK, Lannoo MJ. 2005. Rana clamitans Latreille (1801) Green Frog. In: M Lannoo, editor. Status and Conservation of North American Amphibians. 1st ed. Berkeley (CA): University of California Press. p. 549-552.

Pearson GA, Ayers AD, Eberhard DL. 1966. Relative salt tolerance of rice during germination and early seedling development. Soil Science. 102:151-156.

Pedersen LB, Randrup TB, Ingerslev M. 2000. Effects of road distance and protective measures on deicing $\mathrm{NaCl}$ deposition and soil solution chemistry in planted median strips. Journal of Arboriculture. 26:238-245.

Pessier AP. 2009. Edematous frogs, urinary tract disease, and disorders of fluid balance in amphibians. Journal of Exotic Pet Medicine. 18:4-13.

Peters NE, Turk JT. 1981. Increases in sodium and chloride in the Mohawk River, New York from the 1950s to the 1970s attributed to road salt. Water Resources Bulletin. 17:586-98.

Pollock SJ. Remediating highway deicing salt contamination of public and private water supplies in Massachusetts. In: D'Itri FM, ed. Chemical Deicers and the Environment. 1st ed. Boca Raton (FL): Lewis Publishers. 1992. p. 519-538.

R Development Core Team. 2010. R: A Language and Environment for Statistical Computing, version 2.11.1. R. Foundation for Statistical Computing, Vienna, Austria

Ramakrishna D, Viraraghavan T. 2005. Environmental impact of chemical deicers- a review. Water, Air, and Soil Pollution. 166:49-63.

Relyea RA. 2001. Morphological and behavioral plasticity of larval anurans in response to different predators. Ecology. 82:523-540. 
Reijnen R, Foppen R, Ter Braak C, Thissen J. 1995. The effects of car traffic on breeding bird populations in woodland. 3. Reduction of density in relation to the proximity of main roads. Journal of Applied Ecology. 32:187-202.

Richburg J, Patterson III JA, Lovenstein F. 2001. Effects of Road Salt and Phragmites australis invasion on the vegetation of a western Massachusetts calcareous lake-basin fen. Wetlands. 21:247-255.

Robidoux PY, Delisle CE. 2001. Ecotoxicological evaluation of three deicers $(\mathrm{NaCl}$, NaFo, CMA) - Effect on terrestrial organisms. Ecotoxicology and Environmental Safety. 48:128-139.

Sanzo D, Hecnar SJ. 2006. Effects of road de-icing salt $(\mathrm{NaCl})$ on larval wood frogs (Rana sylvatica). Environmental Pollution 140:247-256.

Schulkin J. 1991. Sodium Hunger: The Search for a Salty Taste. Cambridge University Press. New York, New York.

Scott JB, Steward CR, Stober QJ. 1986. Effects of urban development on fish population dynamics in Kelsey Creek, Washington. Transactions of the American Fisheries Society. 115:555-567.

Seigel RA. 1983. Natural survival of eggs and tadpoles of the wood frog, Rana sylvatica. Copeia. 1983:1096-1098.

Stebbins RC, Cohen NW. 1995. A Natural History of Amphibians. 1st ed. Princeton (NJ) Princeton University Press. 332 p.

Sucoff E, Hong SG, Wood A. 1976. NaCl and twig dieback along highways and cold hardiness of highway versus garden twigs. Canadian Journal of Botany. 54:2268-2271. 
Sutcliffe DW. 1961. Studies on salt and water balance in caddis larvae (Trichoptera): I. Osmotic and ionic regulation of body fluids in Limnephilus affinis Curtis. Journal of Experimental Biology. 38:501-519.

Tchobanoglous G, Schroeder ED. 1985. Water Quality, Vol.1. Reading (MA): AddisonWesley Publishing Company. 768 p.

Trainer DO, Karstad L. 1960. Salt poisoning in Wisconsin wildlife. Journal of the American Veterinarian Medical Association. 13: 614-617.

Trombulak SC, Frissell CA. 2000. Review of ecological effects of roads on terrestrial and aquatic communities. Conservation Biology. 14:18-30.

Turtle SL. 2000. Embryonic survivorship of the spotted salamander (Ambystoma maculatum) in roadside and woodland vernal pools in southeastern New Hampshire. Journal of Herpetology 34:60-67.

US EPA. 1988. Ambient water quality standards for chloride. Criteria and Standards Division. EPA Publication Number 440588001. Washington(DC).

United States Environmental Protection Agency. 1993. Methods for measuring the acute toxicity of effluents and receiving waters to freshwater and marine organisms. EPA 600/4-90/027F. Technical Report. Cincinnati (OH).

Viskari EL, Karenlampi L. 2000. Roadside Scots pine as an indicator of deicing salt use A comparative study from two consecutive winters. Water, Air and Soil Pollution. 122:405-419.

Welsh HH, Olivier LM. 1998. Stream amphibians as indicators of ecosystem stress: a case study from California's redwoods. Ecological Applications. 8:1118-1132. 
Wilcox DA. 1986. The effects of deicing salts on water chemistry in Pinhook bog, Indiana. Water Resources Bulletin. 22:57-65.

Williams DD, Williams NE, Cao Y. 2000. Road salt contamination of groundwater in a major metropolitan area and development of a biological index to monitor its impact. Water Research. 1:127-138.

Zinabu GM, Chapman LJ, Chapman, CA. 2002. Specific conductance as a predictor of total cations and salinity in Ethiopian lakes and rivers: revisiting earlier models. Limnologica. 32:21-26.

Zedler JB, Paling E, McComb A. 1990. Differential responses to salinity help explain the replacement of native Juncus kraussii by Typha orientalis in Western Australian salt marshes. Australian Journal of Ecology. 15:57-72. 


\section{Appendix A: Request for Permission to Reproduce Previously Published Material}

The following letter is for Chapter 2 and represents written permission from John Wiley and Sons to publish material from a recent publication in the journal Environmental Toxicology and Chemistry.

American Society

Apr 11, 2012

This is a License Agreement between Meagan L Harless ("You") and John Wiley and Sons ("John Wiley and Sons") provided by Copyright Clearance Center ("CCC"). The license consists of your order details, the terms and conditions provided by John Wiley and Sons, and the payment terms and conditions.

All payments must be made in full to CCC. For payment instructions, please see information listed at the bottom of this form.

License Number $\quad 2885960274716$

License date Apr 11, 2012

Licensed content publisher

Licensed content publication

John Wiley and Sons

Environmental Toxicology and Chemistry

Licensed content title Effects of six chemical deicers on larval wood frogs (Rana sylvatica) Licensed content author Meagan L. Harless,Casey J Huckins,Jacqualine B. Grant,Thomas G. Pypker 
Licensed content date Jul 1, 2011

Start page $\quad 1637$

End page $\quad 1641$

Type of use Dissertation/Thesis Requestor type Author of this Wiley article Format Print and electronic Portion Full article

Will you be translating? No

Order reference number None

Total 0.00 USD

\section{TERMS AND CONDITIONS}

This copyrighted material is owned by or exclusively licensed to John Wiley \& Sons, Inc. or one of its group companies (each a "Wiley Company") or a society for whom a Wiley Company has exclusive publishing rights in relation to a particular journal (collectively WILEY"). By clicking "accept" in connection with completing this licensing transaction, you agree that the following terms and conditions apply to this transaction (along with the billing and payment terms and conditions established by the Copyright Clearance Center Inc., ("CCC's Billing and Payment terms and conditions"), at the time that you opened your Rightslink account (these are available at any time at http://myaccount.copyright.com)

\section{Terms and Conditions}

1. The materials you have requested permission to reproduce (the "Materials") are protected by copyright.

2. You are hereby granted a personal, non-exclusive, non-sublicensable, non-transferable, worldwide, limited license to reproduce the Materials for the purpose specified in the licensing process. This license is for a one-time use only with a maximum distribution equal to the number that you identified in the licensing process. Any form of republication granted by this licence must be completed within two years of the date of 
the grant of this licence (although copies prepared before may be distributed thereafter). The Materials shall not be used in any other manner or for any other purpose. Permission is granted subject to an appropriate acknowledgement given to the author, title of the material/book/journal and the publisher. You shall also duplicate the copyright notice that appears in the Wiley publication in your use of the Material. Permission is also granted on the understanding that nowhere in the text is a previously published source acknowledged for all or part of this Material. Any third party material is expressly excluded from this permission.

3. With respect to the Materials, all rights are reserved. Except as expressly granted by the terms of the license, no part of the Materials may be copied, modified, adapted (except for minor reformatting required by the new Publication), translated, reproduced, transferred or distributed, in any form or by any means, and no derivative works may be made based on the Materials without the prior permission of the respective copyright owner. You may not alter, remove or suppress in any manner any copyright, trademark or other notices displayed by the Materials. You may not license, rent, sell, loan, lease, pledge, offer as security, transfer or assign the Materials, or any of the rights granted to you hereunder to any other person.

4. The Materials and all of the intellectual property rights therein shall at all times remain the exclusive property of John Wiley \& Sons Inc or one of its related companies (WILEY) or their respective licensors, and your interest therein is only that of having possession of and the right to reproduce the Materials pursuant to Section 2 herein during the continuance of this Agreement. You agree that you own no right, title or interest in or to the Materials or any of the intellectual property rights therein. You shall have no rights hereunder other than the license as provided for above in Section 2. No right, license or interest to any trademark, trade name, service mark or other branding ("Marks") of WILEY or its licensors is granted hereunder, and you agree that you shall not assert any such right, license or interest with respect thereto. 
5. NEITHER WILEY NOR ITS LICENSORS MAKES ANY WARRANTY OR REPRESENTATION OF ANY KIND TO YOU OR ANY THIRD PARTY, EXPRESS, IMPLIED OR STATUTORY, WITH RESPECT TO THE MATERIALS OR THE ACCURACY OF ANY INFORMATION CONTAINED IN THE MATERIALS, INCLUDING, WITHOUT LIMITATION, ANY IMPLIED WARRANTY OF MERCHANTABILITY, ACCURACY, SATISFACTORY QUALITY, FITNESS FOR A PARTICULAR PURPOSE, USABILITY, INTEGRATION OR NON-INFRINGEMENT AND ALL SUCH WARRANTIES ARE HEREBY EXCLUDED BY WILEY AND ITS LICENSORS AND WAIVED BY YOU.

6. WILEY shall have the right to terminate this Agreement immediately upon breach of this Agreement by you.

7. You shall indemnify, defend and hold harmless WILEY, its Licensors and their respective directors, officers, agents and employees, from and against any actual or threatened claims, demands, causes of action or proceedings arising from any breach of this Agreement by you.

8. IN NO EVENT SHALL WILEY OR ITS LICENSORS BE LIABLE TO YOU OR ANY OTHER PARTY OR ANY OTHER PERSON OR ENTITY FOR ANY SPECIAL, CONSEQUENTIAL, INCIDENTAL, INDIRECT, EXEMPLARY OR PUNITIVE DAMAGES, HOWEVER CAUSED, ARISING OUT OF OR IN CONNECTION WITH THE DOWNLOADING, PROVISIONING, VIEWING OR USE OF THE MATERIALS REGARDLESS OF THE FORM OF ACTION, WHETHER FOR BREACH OF CONTRACT, BREACH OF WARRANTY, TORT, NEGLIGENCE, INFRINGEMENT OR OTHERWISE (INCLUDING, WITHOUT LIMITATION, DAMAGES BASED ON LOSS OF PROFITS, DATA, FILES, USE, BUSINESS OPPORTUNITY OR CLAIMS OF THIRD PARTIES), AND WHETHER OR NOT THE PARTY HAS BEEN ADVISED OF THE POSSIBILITY OF SUCH DAMAGES. THIS LIMITATION SHALL APPLY NOTWITHSTANDING ANY FAILURE OF ESSENTIAL PURPOSE OF ANY LIMITED REMEDY PROVIDED HEREIN. 
9. Should any provision of this Agreement be held by a court of competent jurisdiction to be illegal, invalid, or unenforceable, that provision shall be deemed amended to achieve as nearly as possible the same economic effect as the original provision, and the legality, validity and enforceability of the remaining provisions of this Agreement shall not be affected or impaired thereby.

10. The failure of either party to enforce any term or condition of this Agreement shall not constitute a waiver of either party's right to enforce each and every term and condition of this Agreement. No breach under this agreement shall be deemed waived or excused by either party unless such waiver or consent is in writing signed by the party granting such waiver or consent. The waiver by or consent of a party to a breach of any provision of this Agreement shall not operate or be construed as a waiver of or consent to any other or subsequent breach by such other party.

11. This Agreement may not be assigned (including by operation of law or otherwise) by you without WILEY's prior written consent.

12. Any fee required for this permission shall be non-refundable after thirty (30) days from receipt.

13. These terms and conditions together with CCC's Billing and Payment terms and conditions (which are incorporated herein) form the entire agreement between you and WILEY concerning this licensing transaction and (in the absence of fraud) supersedes all prior agreements and representations of the parties, oral or written. This Agreement may not be amended except in writing signed by both parties. This Agreement shall be binding upon and inure to the benefit of the parties' successors, legal representatives, and authorized assigns.

14. In the event of any conflict between your obligations established by these terms and conditions and those established by 
CCC's Billing and Payment terms and conditions, these terms and conditions shall prevail.

15. WILEY expressly reserves all rights not specifically granted in the combination of (i) the license details provided by you and accepted in the course of this licensing transaction, (ii) these terms and conditions and (iii) CCC's Billing and Payment terms and conditions.

16. This Agreement will be void if the Type of Use, Format, Circulation, or Requestor Type was misrepresented during the licensing process.

17. This Agreement shall be governed by and construed in accordance with the laws of the State of New York, USA, without regards to such state's conflict of law rules. Any legal action, suit or proceeding arising out of or relating to these Terms and Conditions or the breach thereof shall be instituted in a court of competent jurisdiction in New York County in the State of New York in the United States of America and each party hereby consents and submits to the personal jurisdiction of such court, waives any objection to venue in such court and consents to service of process by registered or certified mail, return receipt requested, at the last known address of such party.

Wiley Open Access Terms and Conditions

All research articles published in Wiley Open Access journals are fully open access: immediately freely available to read, download and share. Articles are published under the terms of the Creative Commons Attribution Non Commercial License. which permits use, distribution and reproduction in any medium, provided the original work is properly cited and is not used for commercial purposes. The license is subject to the Wiley Open Access terms and conditions:

Wiley Open Access articles are protected by copyright and are posted to repositories and websites in accordance with the terms of the Creative Commons Attribution Non 
Commercial License. At the time of deposit, Wiley Open Access articles include all changes made during peer review, copyediting, and publishing. Repositories and websites that host the article are responsible for incorporating any publisher-supplied amendments or retractions issued subsequently.

Wiley Open Access articles are also available without charge on Wiley's publishing platform, Wiley Online Library or any successor sites.

Use by non-commercial users

For non-commercial and non-promotional purposes individual users may access, download, copy, display and redistribute to colleagues Wiley Open Access articles, as well as adapt, translate, text- and data-mine the content subject to the following conditions:

The authors' moral rights are not compromised. These rights include the right of "paternity" (also known as "attribution" - the right for the author to be identified as such) and "integrity" (the right for the author not to have the work altered in such a way that the author's reputation or integrity may be impugned).

Where content in the article is identified as belonging to a third party, it is the obligation of the user to ensure that any reuse complies with the copyright policies of the owner of that content.

If article content is copied, downloaded or otherwise reused for non-commercial research and education purposes, a link to the appropriate bibliographic citation (authors, journal, article title, volume, issue, page numbers, DOI and the link to the definitive published version on Wiley Online Library) should be maintained. Copyright notices and disclaimers must not be deleted. 
Any translations, for which a prior translation agreement with Wiley has not been agreed, must prominently display the statement: "This is an unofficial translation of an article that appeared in a Wiley publication. The publisher has not endorsed this translation."

Use by commercial "for-profit" organisations

Use of Wiley Open Access articles for commercial, promotional, or marketing purposes requires further explicit permission from

Wiley and will be subject to a fee. Commercial purposes include:

Copying or downloading of articles, or linking to such articles for further redistribution, sale or licensing;

Copying, downloading or posting by a site or service that incorporates advertising with such content;

The inclusion or incorporation of article content in other works or services (other than normal quotations with an appropriate citation) that is then available for sale or licensing, for a fee (for example, a compilation produced for marketing purposes, inclusion in a sales pack)

Use of article content (other than normal quotations with appropriate citation) by forprofit organisations for promotional purposes

Linking to article content in e-mails redistributed for promotional, marketing or educational purposes;

Use for the purposes of monetary reward by means of sale, resale, licence, loan, transfer or other form of commercial exploitation such as marketing products 
Print reprints of Wiley Open Access articles can be purchased from:

corporatesales@wiley.com

Other Terms and Conditions:

BY CLICKING ON THE "I AGREE..." BOX, YOU ACKNOWLEDGE THAT YOU HAVE READ AND FULLY UNDERSTAND EACH OF THE SECTIONS OF AND PROVISIONS SET FORTH IN THIS AGREEMENT AND THAT YOU ARE IN AGREEMENT WITH AND ARE WILLING TO ACCEPT ALL OF YOUR OBLIGATIONS AS SET FORTH IN THIS AGREEMENT.

v1.7

If you would like to pay for this license now, please remit this license along with your payment made payable to "COPYRIGHT CLEARANCE CENTER" otherwise you will be invoiced within 48 hours of the license date. Payment should be in the form of a check or money order referencing your account number and this invoice number RLNK500758258. Once you receive your invoice for this order, you may pay your invoice by credit card. Please follow instructions provided at that time.

Make Payment To: Copyright Clearance Center Dept 001

P.O. Box 843006

Boston, MA 02284-3006

For suggestions or comments regarding this order, contact RightsLink Customer Support: custom ercare@copy right.com or +1-877-622-5543 (toll free in the US) or +1-978-6462777.

Gratis licenses (referencing $\$ 0$ in the Total field) are free. Please retain this printable license for your reference. No payment is required. 